\title{
Rubiaceae na Serra Geral de Licínio de Almeida, Bahia, Brasil ${ }^{1}$
}

Rubiaceae of Serra Geral de Licínio de Almeida, Bahia, Brazil

\author{
Rodrigo L. Borges ${ }^{2,6}$, Jomar G. Jardim ${ }^{3,4}$ \& Nádia Roque ${ }^{5}$
}

\begin{abstract}
Resumo
Entre as áreas que são reconhecidas pela carência de inventários florísticos no estado da Bahia, destaca-se a região sudoeste, mais precisamente as áreas que compreendem o Espinhaço Setentrional. O objetivo deste estudo foi realizar o levantamento florístico e taxonômico de Rubiaceae da Serra Geral de Licínio de Almeida (SGLA), Bahia. Foram realizadas dez expedições de campo para coleta entre julho de 2012 e maio de 2015, abrangendo todas as fitofisionomias existentes na área. Os materiais coletados foram processados e depositados nos herbários ALCB e HUEFS. Materiais de referência foram também analisados em visita aos herbários ALCB, CEPEC, HRB, HUEFS, RB, SPF. Foram reconhecidas 43 espécies, distribuídas em 28 gêneros, sendo Declieuxia (5 spp.), Borreria (3 spp.), Cordiera (3 spp.) e Psychotria (3 spp.) os gêneros mais diversos e, seguindo os estudos florísticos prévios na Cadeia do Espinhaço, houve um grande número de gêneros (19) com apenas uma única espécie. Psyllocarpus asparagoides, Psyllocarpus laricoides, Stachyarrhena reflexa são endêmicas da Bahia e Minas Gerais; Declieuxia passerina e Galianthe peruviana são novas ocorrências para a Bahia, e duas espécies (Randia sp. e Staelia sp.) são possivelmente inéditas para a ciência. São apresentados chaves de identificação genérica e específica, descrições, comentários taxonômicos para as espécies, além de fotos e ilustrações.
\end{abstract}

Palavras-chave: diversidade florística, Espinhaço Setentrional, taxonomia.

\begin{abstract}
One of the areas in Bahia that is known by the lack of floristic inventories is the southwest region, more precisely the area that comprises the septentrional part of the Espinhaço Range. The aim of this study was to carry out a floristic and taxonomic survey of Rubiaceae of the Serra Geral of Licínio de Almeida (SGLA), Bahia. Ten field trips were conducted between July 2012 and May 2015, covering all existing vegetation types in the area. The collected material was processed and deposited at HUEFS and ALCB herbaria. Reference materials were also analyzed in visits to CEPEC, HRB, HUEFS, RB and SPF. A number of 43 species distributed in 28 genera were recognized, with Declieuxia (5 spp.), Borreria (3 spp.), Cordiera (3 spp.) and Psychotria (3 spp.) as the most diverse genera. Following previous floristic studies in the Espinhaço Range, there is alarge number of genera (19) represented by a single species. Psyllocarpus asparagoides, Psyllocarpus laricoides and Stachyarrhena reflexa are endemic to Minas Gerais and Bahia; Declieuxia passerina and Galianthe peruviana are new records for Bahia, and two species are considered new for science (Randia sp. and Staelia sp.). Keys to genera and species identification, descriptions, taxonomic and biologic comments for all species are presented, as well as images and illustrations.
\end{abstract}

Key words: floristic, Espinhaço Septentrional, taxonomy.

\footnotetext{
${ }^{1}$ Parte da dissertação de Mestrado do primeiro autor.

${ }^{2}$ Universidade Estadual de Feira de Santana, PPGBot, Av. Transnordestina s/n, Novo Horizonte, 44036-900, Feira de Santana, BA, Brasil.

${ }^{3}$ Universidade Federal do Sul da Bahia, Inst. Humanidades, Artes e Ciências, Campus Jorge Amado, 45613-204, Itabuna, BA, Brasil

${ }^{4}$ Herbário do Centro de Pesquisas do Cacau, CEPEC, Rod. Ilhéus-Itabuna, 45650-970, Ilhéus, BA, Brasil.

${ }^{5}$ UFBA, Herbário Alexandre Leal Costa, R. Barão de Jeremoabo s/n, Campus Universitário de Ondina, 40170-115, Salvador, BA, Brasil.

${ }^{6}$ Autor para correspondência: rodrigolopesborges89@gmail.com
} 


\section{Introdução}

Rubiaceae é considerada a quarta maior família entre as angiospermas, compreendendo 13.143 espécies em 611 gêneros (Davis et al. 2009). Pode ser caracterizada por apresentar hábito geralmente arbustivo, folhas simples opostas, estípula interpeciolar, flores com corola gamopétala e ovário ínfero (exceto em Pagamea) bicarpelar (Robbrecht 1988; Davis et al. 2009; Delprete \& Jardim 2012).

A família apresenta distribuição cosmopolita, embora seu centro de diversidade esteja na região Neotropical, especialmente nas florestas úmidas de baixa altitude, onde estima-se que existam ca. 5.000 espécies (Delprete 2004). No Brasil, Rubiaceae está representada por 1.392 espécies, concentradas principalmente nos domínios Amazônico, Atlântico e no Cerrado (Barbosa et al. 2016). A Bahia por sua vez, apresenta 368 espécies, sendo considerado o segundo estado brasileiro com maior riqueza de espécies, o que é reflexo da elevada heterogeneidade de formações vegetais existentes (Giulietti et al. 2006).

Embora apresente elevada riqueza específica na Bahia, são poucas os estudos florísticos e taxonômicos com ênfase em Rubiaceae no estado. Até o momento, foram feitos apenas três trabalhos florísticos focando a família, sendo dois na Chapada Diamantina [Pico das Almas - Zappi \& Stannard (1995); Serra da Fumaça - Sousa et al. (2013)] e um em área de Caatinga na Reserva Serra Branca no Raso da Catarina, porção Nordeste do estado (Varjão et al. 2013). Em todos esses trabalhos, a família apresentou grande diversidade específica, com elevada proporção de gêneros com apenas uma única espécie e, dentre esses gêneros, muitas espécies foram registradas como endêmicas de áreas montanhosas.

Entre as áreas que são reconhecidas pela ausência de inventários florísticos no estado, destaca-se a região sudoeste, mais precisamente a porção baiana do Espinhaço Setentrional, que é formada por um conjunto de três serras denominadas Serra do Boqueirão, Serra do Estreito e Serra Geral (CRPM 1982).

A Serra Geral do município de Licínio de Almeida (SGLA) estende-se por uma área longa e estreita, a oeste do município, e apresenta um mosaico de formações vegetais, apresentando fitofisionomias de campo rupestre, Cerrado sensu stricto, floresta estacional e caatinga sobre afloramento rochoso (Campos et al. 2016) e, embora desconhecida quanto à sua biodiversidade, tem sido considerada prioritária para a conservação (Taylor \& Zappi 2004).

Os inventários florísticos realizados na SGLA, incluindo famílias bem representativas, como Fabaceae, Caesalpinioideae (Azevedo 2014), Asteraceae (Santana 2013) e Euphorbiaceae (Hurbath et al. 2016), reconheceram um elevado número de novas ocorrências para o estado (Alves et. al. 2015), bem como a descrição de espécies novas para a ciência (Roque \& Santana 2014).

Sendo assim, o objetivo principal deste trabalho foi produzir um inventário florístico e taxonômico para a família Rubiaceae na Serra Geral de Licínio de Almeida, Bahia, provendo dados de uma área carente em estudos florísticos e contribuindo para o conhecimento da Flora da Bahia.

\section{Material e Métodos}

A Serra Geral de Licínio de Almeida (SGLA) está localizada na porção Setentrional da Serra do Espinhaço, na região sudoeste do estado da Bahia (CRPM 2008). A SGLA ocupa uma faixa longa e estreita a oeste do município de Licínio de Almeida, entre as coordenadas $14^{\circ} 25^{\prime}-14^{\circ} 50^{\prime} \mathrm{S}$ e $42^{\circ} 30^{\prime}-42^{\circ} 35^{\prime} \mathrm{W}$, na divisa com os municípios de Caculé, Caetité, Jacaraci, Pindaí e Urandi (Fig.1), caracterizando-se por apresentar regime de chuvas entre 700-900 mm, concentrado no mês de janeiro (SEDIR 2007).

Campos et al. (2016) reconheceram para a SGLA cinco fitofisionomias, subdivididas em dois tipos de formações vegetais, florestas (estacional semi-decidual e estacional decidual) e savanas (cerrado sensu stricto, campo rupestre e caatinga rupestre), de acordo com critérios estabelecidos para estas fitofisionomias (Coutinho 1978; Giulietti 1987; IBGE 2012) (Fig. 2).

O inventário florístico foi realizado por meio de dez expedições de coleta entre julho de 2012 e maio de 2015, abrangendo 14 pontos de coleta e todas as fitofisionomias existentes na região (Fig. 1). O material fértil foi coletado e herborizado segundo Mori et al. (1989) e as exsicatas depositadas nos herbários ALCB e HUEFS, com duplicatas enviadas para o CEPEC. Foram também consultadas as coleções dos herbários ALCB, CEPEC, HRB, HRCB, HUEFS, SPF e RB (acrônimos conforme Thiers, continuamente atualizado), a fim de analisar materiais provenientes da área de estudo, bem como utilizar outros materiais como referência para identificação do material coletado. 

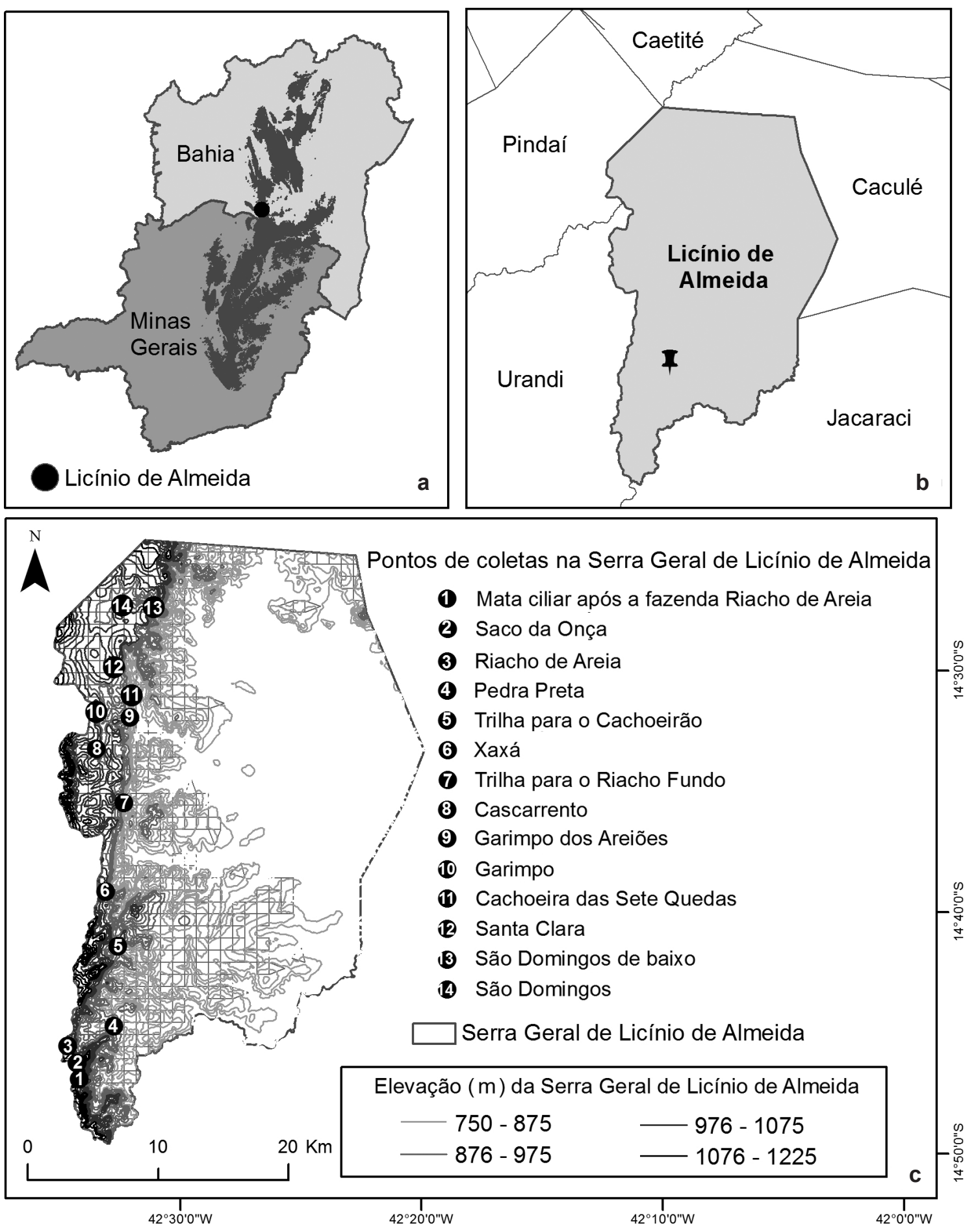

Figura 1 - a. Serra Geral de Licínio de Almeida na porção central da Cadeia do Espinhaço, Bahia; b. Licínio de Almeida e municípios adjacentes; c. Serra Geral na porção oeste do município e pontos de coleta cobrindo toda a extensão da serra.

Figure 1 - a. Serra Geral of Licínio de Almeida in the center portion of Espinhaço Range, Bahia; b. Licínio de Almeida and neighboring municipalities; c. Serra Geral in the west portion of the municipality and collection points covering the entire length. 

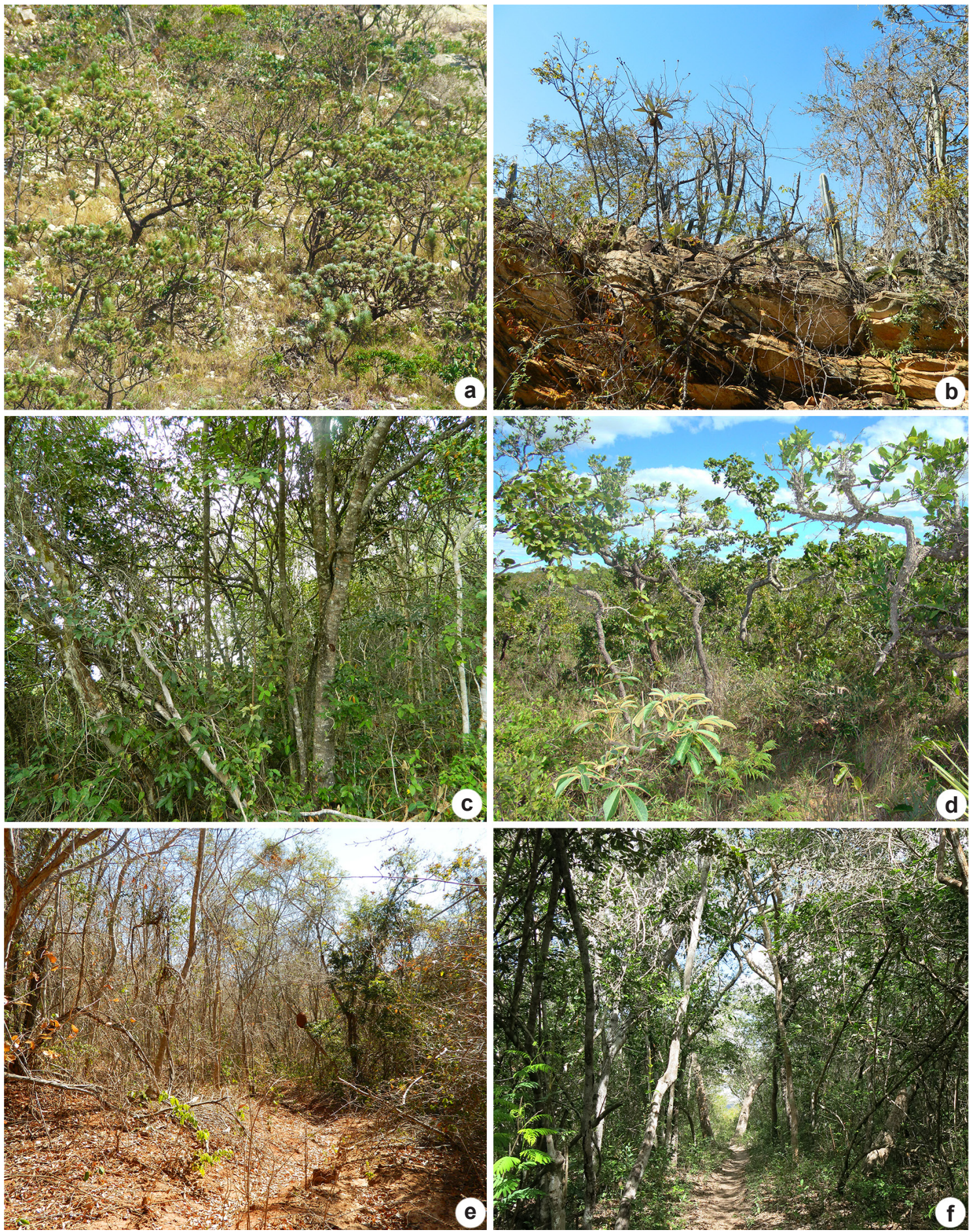

Figura 2 - a-d. fitofisionomias da Serra Geral de Licínio de Almeida - a. campo rupestre; b. caatinga; c. floresta estacional semidecidual; d. cerrado. e-f. floresta estacional decidual - e. estação seca; f. estação chuvosa. (a,d. $N$. Roque; b,c,e. L. Campos; f. F. Hurbath).

Figure 2 - a-d. phytophysiognomies of Serra Geral of Licinio de Almeida - a. rocky outcrops; b. caatinga; c. semidecidual seasonal forest; d. cerrado. e-f. deciduous forest - e. dry season; f. rainy season. (a,d. N. Roque; b,c,e. L. Campos; f. F. Hurbath). 
A identificação taxonômica, elaboração de comentários morfológicos e distribuição das espécies foram feitos com base em revisões taxonômicas [Augusta - Delprete (1997), Borreria - Cabral et al. (2011), Coussarea Pereira (2007), Declieuxia - Kirkbride (1976), Galianthe - Cabral et al. (2009), Margaritopsis - Taylor (2005), Mitracarpus - Souza et al. (2010), Palicourea - Taylor (1995), Posoqueria - Macias (1988), Psyllocarpus - Kirkbride (1979), Richardia - Lewis \& Oliver (1974), Sabicea - Wernham (1914) e Tocoyena - Prado (1987)], floras e levantamentos florísticos (e.g., Mendaçolli et al. 2007; Campos et al. 2006; Delprete 2010; Sousa et al. 2013; Varjão et al. 2013; Zappi et al. 2014), protólogos, visualização de e-tipos, além de consulta às plataformas online, Flora do Brasil (BFG 2015) e Rubiaceae World Checklist (Govaerts 2016).

Para o tratamento taxonômico foram elaboradas descrições genéricas (exceto gêneros monoespecíficos), com base nas revisões e floras listadas acima, e de espécies, em ordem alfabética, seguida do material examinado, distribuição geográfica e comentários taxonômicos ou biológicos. Gêneros com mais de uma espécie foram acompanhados de chave dicotômica. Para as descrições das espécies utilizou-se Radford et al. (1974) e Beentje (2010). As medições foram feitas através de paquímetro digital e papel milimetrado. O termo 'subséssil' foi utilizado para estruturas entre $0,2-1 \mathrm{~mm}$ compr.

\section{Resultados e Discussão}

\section{Chave para gêneros de Rubiaceae ocorrentes na SGLA, Licínio de Almeida, Bahia}

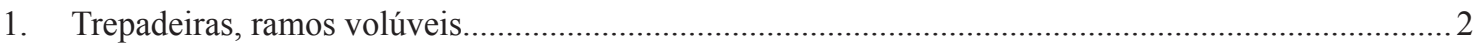

2. Lâmina foliar elíptica, 3,2-4,1 cm compr.; inflorescência umbeliforme (Fig. 5h); flores alvas, corola sub-rotácea ca. $0,16 \mathrm{~cm}$ compr.; sementes ferrugíneas 9. Emmeorhiza

2'. Lâmina foliar lanceolada a ovada, 4,3-5,2 cm compr.; inflorescência em dicásios ou tirsos; flores vermelhas, corola tubular 4,6-5,5 cm compr.; sementes negras. 15. Manettia

1'. Ervas, arbustos, subarbustos ou árvores; ramos eretos, escandentes ou prostrados ............................. 3

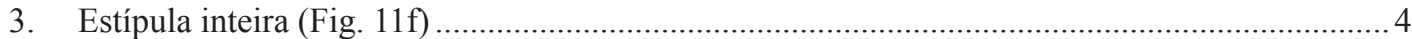

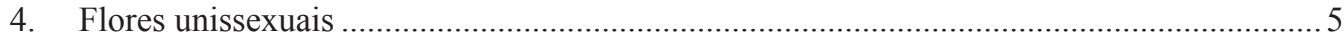

5. Ramos espinescentes (Fig. 5p); flores masculinas organizadas em tirso ou fascículo; lobos do cálice lanceolados. 22. Randia

5'. Ramos inermes (Fig. 11e); flores masculinas organizadas em inflorescência espiciforme ou em glomérulo, lobos do cálice fusionados formando estrutura cupuliforme ........... 6

6. Lâmina foliar obovada; flores masculinas em inflorescência espiciforme (Fig. 11g); fruto elipsoide; sementes aplanadas, 5,5-5,9 mm compr..........26. Stachyarrhena

6'. Lâmina foliar elíptica; flores masculinas em glomérulos (Fig. 5g); frutos globosos; sementes suborbiculares, 3,6-4,7 mm compr. 5. Cordiera

4'. Flores bissexuais

7. Corola campanulada (Fig. 5f), rósea; fruto alvo na maturidade ................ 3. Chiococca

7'. Corola hipocrateriforme ou infundibuliforme (Fig. 3b,1), alva, azul, creme, lilás, vermelha ou vinácea; fruto amarelo, atropurpúreo ou vermelho quando maduros ....................... 8

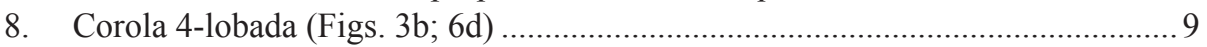

9. Estípula linear com glândulas; fruto esquizocárpico (2-mericarpos), lenticular (Fig. 11d) 8. Declieuxia

9'. Estípula triangular, sem glândulas; fruto carnoso drupáceo ou capsular septicida (Fig. 7b).

10. Erva; fruto capsular

10’. Arbustos ou árvores; fruto carnoso drupáceo

11. Ramos espinescentes; flores com corola vinácea; fruto elipsoide... 4. Chomelia

11'. Ramos inermes; flores com corola alva, creme ou lilás; fruto globoso, subgloboso ou obovoide. 12 
12. Estípula com ápice agudo; inflorescência capituliforme; flores com corola alva; fruto obovoide, compresso lateralmente.

12'. Estípula com ápice aristado; inflorescência em tirso; flores com corola creme ou lilás; fruto globoso ou subgloboso.

13. Flores com corola creme (Fig. 7a); fruto 2-seminado, subgloboso; semente planoconvexa

13'. Flores com corola lilás (Fig. 6d); fruto 1-seminado, globoso; semente escavada ventralmente 10. Faramea

8'. Corola 5-6 lobada 14

14. Lóculos do ovário 1-ovulado; fruto carnoso drupáceo (Figs. 6h,1; 7g)..... 15

15. Prefloração da corola imbricada, corola ca. $4 \mathrm{~cm}$ compr.; fruto 1 -seminado, creme a vináceo quando maduro (Fig. 6h,1); semente oblada ou elipsoide, lisa ....12. Guettarda

15'. Prefloração da corola valvar, corola $0,1-0,7 \mathrm{~cm}$ compr.; fruto 2 -seminado, vermelho quando maduro (Fig. 7g); semente plano convexa, sulcada 16

16. Árvore; ramos cilíndricos lenticelados; lâmina foliar com domacias, margem reta (Fig. 8k-m), 8,1-8,9 cm compr.. 20. Psychotria

16'. Arbusto; ramos costados não lenticelados; lâmina foliar sem domacias, margem revoluta (Fig. $7 \mathrm{~g}$ ), 2,5-5 cm compr. 16. Margaritopsis

14'. Lóculos do ovário 2-pluriovulados; fruto carnoso baga ou seco capsular (Figs. 4g; 8b) ... 17

17. Corola longo tubular (5,1-14,8 cm compr.) (Figs. 3b; 10k)...

18. Ramos lenticelados; corola 6-lobada. 7. Coutarea

18'. Ramos não lenticelados; corola 5-lobada 19

19. Flores com corola vermelha; fruto capsular castanho quando maduro; semente obcônica 1. Augusta

19'. Flores com corola alva ou creme; fruto carnoso, amarelo quando maduro; semente plana ou cuneiforme. 20

20. Árvore; lâmina foliar glabra, estípula ovada, navicular; lobos da corola oblongos, fruto drupáceo. 19. Posoqueria

20'. Arbusto; lâmina foliar tomentosa, estípula triangular, reta; lobos da corola ovados, fruto bacáceo .

28. Tocoyena

17'. Corola curto tubular $(0,3-3,6 \mathrm{~cm}$ compr.). 21

21. Ramos triangulares, indumento denso tomentoso, ferrugíneo (Fig. 9j); folhas trísticas (Fig. 9i), estípula ca. 3,6 cm compr.; lâmina foliar 8,1-15 cm compr., bulada, margem revoluta; fruto cápsula. 23. Remijia

21'. Ramos cilíndricos, indumento denso lanoso, creme (Fig. 10a); folhas opostas, estípula ca. 0,6 cm compr.; lâmina foliar 4,3-5,5 cm compr., lisa, margem inteira; fruto baga.. 25. Sabicea

3'. Estípula bífida ou fimbriada (Figs. 5e; $8 \mathrm{j}$ ) . 22

22. Estípula bífida (Fig. 8j); fruto carnoso drupáceo; semente plano-convexa, sulcada dorsalmente..

23. Flores actinomorfas; corola cilíndrica, alva 20. Psychotria

23'. Flores zigomorfas; corola gibosa (Fig. 5o), amarela... 18. Palicourea

22'. Estípula fimbriada (Fig. 5e), fruto seco capsular ou esquizocárpico; semente alada, elipsoide, oblonga ou obcônica

24. Fruto esquizocárpico (Fig. 5r,s), 2-3 mericarpos, separando-se quando maduros ..............25

25. Flores com cálice e corola 6-lobada, cálice desprendendo-se de fruto; estigma 3-lobado, cocleado; fruto com 3 mericarpos, obovóides, papilosos 24. Richardia

25'. Flores com cálice e corola 4-lobada, cálice persistente no fruto; estigma indiviso, capitado; fruto com 2-mericarpos, plano-convexos, pilosos a glabros. 13. Hexasepalum

24'. Fruto cápsula (Fig. 5d,1,u), 2 mericarpos, expondo as sementes quando maduros ...............26

26. Cápsula longitudinalmente deiscente (Figs. 5d; 9b). 
27. Lâmina foliar 0,5-1,2 cm compr.; inflorescência capituliforme ou em verticilastro (Fig. 8n,o); anteras inclusas; semente plana compressa... 21. Psyllocarpus

27'. Lâmina foliar 1,5-6,9 cm compr.; inflorescência em glomérulo ou tirso (Figs. 3d; 6g); anteras exertas; semente elipsoide ou oblonga. 28

28. Lâmina foliar linear, margem revoluta, ca. $1,5 \mathrm{~cm}$; inflorescência em tirso (Fig. $6 \mathrm{~g}$ )....

28'. Lâmina elíptica a lanceolada, margem plana, 2,5-6,9 cm compr.; inflorescência em glomérulo (Fig. 3d,f) . 2. Borreria

26’. Cápsula com deiscência circuncisa ou transversalmente obliqua (Fig. 51,u) 29

29. Lâmina foliar elíptica; cápsula com deiscência circuncisa (Fig. 51); semente com cicatriz cruciforme dorsal e cicatriz ventral em X (Fig. $5 \mathrm{~m}, \mathrm{n})$..... 17. Mitracarpus

29'. Lâmina foliar linear-lanceolada; cápsula com deiscência transversal oblíqua (Fig. 5u); semente sem cicatriz dorsal e cicatriz ventral longitudinal (Fig. 5v,w)

27. Staelia

1. Augusta Pohl, Flora 12: 118. 1828.

Arbusto ou subarbusto. Ramos eretos, cilíndricos. Folhas opostas, pecioladas; estípula inteira; lâmina foliar lanceolada a oblanceolada. Inflorescência em corimbos reduzidos ou tirsos terminais, pedunculados. Flores pediceladas; cálice 4-lobado; corola 5-lobada, hipocrateriforme, alva ou vermelha; anteras elípticas; ovário 2-locular, muitos óvulos por lóculo, estigma bífido. Fruto seco, capsular, deiscência septícida e loculicida. Semente, diminuta, angular.

Augusta é um gênero pantropical com ca. quatro espécies, das quais duas (Augusta longifolia e Augusta rivalis) são restritas à região neotropical (Govaerts et al. 2016). No Brasil, ocorre apenas Augusta longifolia, nos domínios Amazônico, Atlântico, Caatinga e Cerrado (Delprete 1997). Este gênero caracteriza-se por apresentar flores alvas ou vermelhas, frutos capsulares com deiscência loculicida e septicida e sementes diminutas, angulares (Kirkbride 1997).

1.1. Augusta longifolia (Spreng.) Rehder, Bull. Misc. Inform. Kew 1935: 364. 1935.

Figs. 3a,b; 8a-c

Arbusto até $2 \mathrm{~m}$ alt.. Ramos cilíndricos, verdes, estriados, glabros. Folhas opostas, pecioladas (pecíolo 2,5-6,8 $\mathrm{mm}$ compr.); estípula triangular, aristada, ca. $5 \times 3 \mathrm{~mm}$, glabra externamente, pilosa internamente; lâmina estreitamente elíptica a oblanceolada, ápice acuminado, base atenuada, 6-8,6 × 1,6-2,1 cm, lisa, cartácea, discolor, glabra. Tirso terminal, pedunculado (pedúnculo 0,5-1,1 cm compr.); brácteas lanceoladas, ca. 5,8 $\times 1 \mathrm{~mm}$, ferrugíneas, glabras. Flores pediceladas (pedicelo ca. $7,3 \mathrm{~mm}$ compr.); lobos do cálice triangulares, 2,5-4,2 $\times 1,3-1,7 \mathrm{~mm}$, verde a ferrugíneos, glabros; corola ca. 5,6 cm compr., tubo ca. 5,1 cm compr., vermelho, piloso, lobos ovados, ápice agudo, vermelhos, glabros; anteras ca. $6,8 \times 1,3 \mathrm{~mm}$, amarelas, glabras; estilete ca. $5 \mathrm{~cm}$ compr., creme-esverdeado, piloso na base do estilete, lobos do estigma ca. 3,3 mm compr, cremes, glabros. Fruto obovóide, 1,6-1,7 × 0,6-0,7 $\mathrm{cm}$, verde a castanho quando maduro, glabro. Semente obcônica, ca. $1,2 \times 0,8 \mathrm{~mm}$, ferrugínea, lisa. Material examinado: Licínio de Almeida, Cascarrento, 16.IX.2011, fl. e fr., 1455'25'S, 4256'97'W, N. Roque et al. 3325 (ALCB); Córrego do Santana, 15.IX.2011, fl. e fr., 1435'56”S, 42³2'59”'W, N. Roque et al. 3291 (ALCB, CEPEC); Trilha ao lado da cachoeira das sete quedas, 22.V.2013, fl. e fr., 14³1'01,5”'S, 42³2'00'W, R.L. Borges et al. 134 (ALCB, CEPEC, HUEFS); Trilha ao lado da cachoeira das sete quedas, 4.XI.2013, fl., 14³7'42,2”'S, 42³0'39,9'W, R.L. Borges et al. 174 (ALCB, HUEFS); Cachoeira das Sete Quedas, 6.VIII.2014, fl., 14 $51^{\circ}$ '63'S, 4253'27,8”'W, N. Roque et al. 4456 (ALCB).

Augusta longifolia é uma espécie endêmica do Brasil, amplamente distribuída nos domínios fitogeográficos brasileiros, associada a matas ciliares do domínio Atlântico e Cerrado (Delprete 1997). Na SGLA, A. longifolia é encontrada na margem de matas de galeria e caracteriza-se por apresentar lâmina foliar estreitamente elíptica a oblanceolada, flores vistosas, vermelhas e sementes obcônicas (Fig. 2 a-c).

2. Borreria G.Mey., Prim. Fl. Esseq. 79. 1818.

Arbustos, subarbustos ou ervas. Ramos eretos ou prostrados, cilíndricos ou angulares. Folhas opostas ou verticiladas, sésseis a pecioladas; estípula inteira ou fimbriada; lâmina foliar elíptica, linear, lanceolada ou ovada. Inflorescência em glomérulo, terminal ou axilar. Flores pediceladas a sésseis; cálice 4-lobado, verdes a róseos, persistente no fruto; corola 4-lobada, hipocrateriforme, alva a lilás; anteras oblongas, excertas; ovário 2-locular, um 

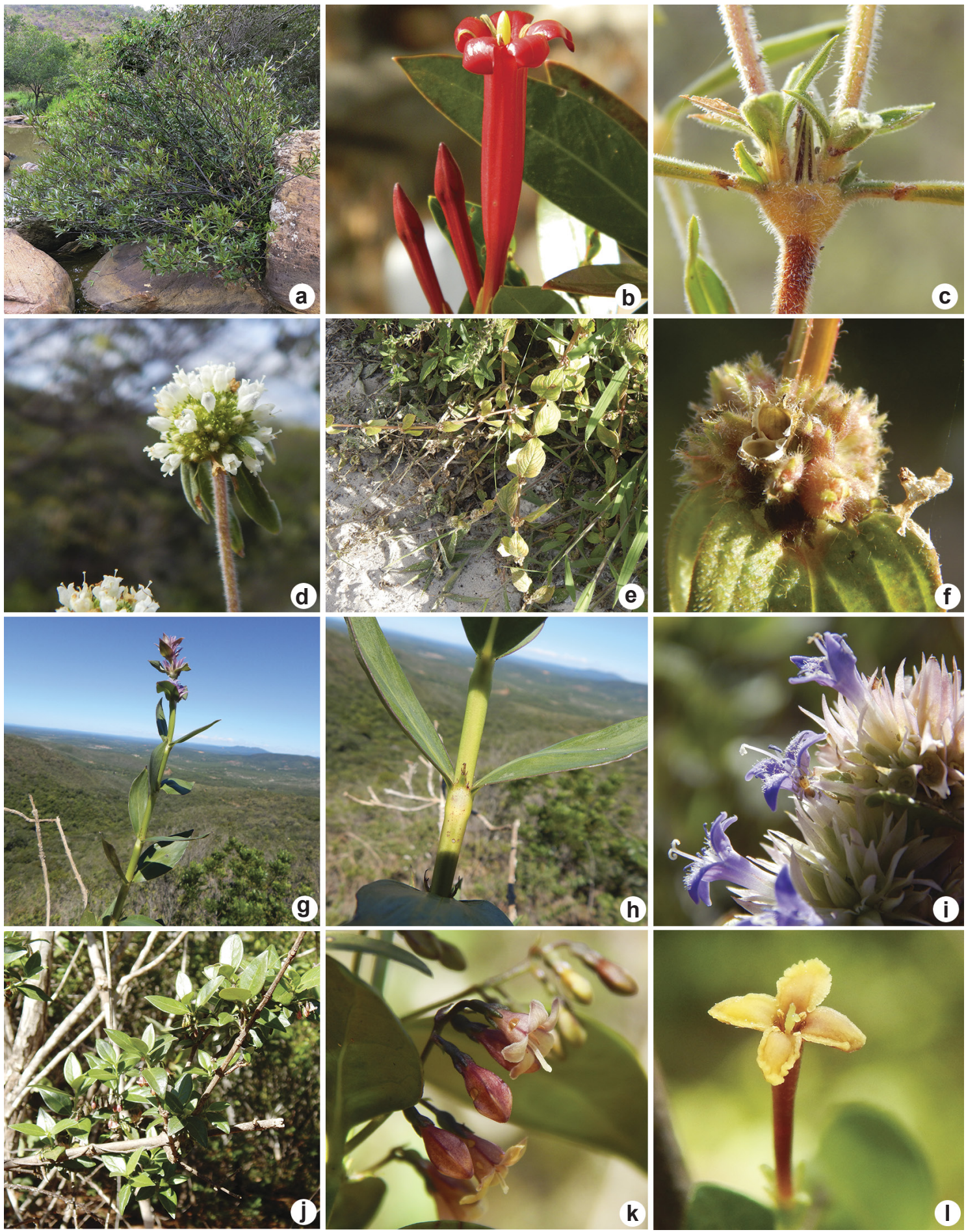

Figura 3 - a,b. Augusta longifolia - a. hábito; b. flor. c,d. Borreria capitata - c. estípula fimbriada; d. glomérulo terminal. e,f. Borreria latifolia - e. hábito; f. glomérulo axilar, em destaque frutos passados. g-i. Borreria poaya - g. hábito; h. estípula; i. glomérulo. j,k. Chiococca alba - j. ramos com flores; k. flores. 1. Chomelia obtusa - flor. (b. L. Campos).

Figure 3 - a,b. Augusta longifolia - a. habit; b. flower. c,d. Borreria capitata - c. fimbriate stipule; d. terminal gomerule. e,f. Borreria latifolia - e. habit; f. axilar glomerule showing the dry fruits. g-i. Borreria poaya - g. habit; h. stipule; i. glomerule. j,k. Chiococca $a l b a-\mathrm{j}$. flowering branches; k. flowers. 1. Chomelia obtusa - flowers (b. L. Campos). 
óvulo por lóculo, estigma bífido ou capitado. Fruto seco capsular com 2-mericarpos, septicida, unidos à base quando deiscentes ou apresentando linha media longitudinal quando indeiscente. Semente elipsoide ou oblonga, reticulada-foveolada, sulcada ventralmente.

Borreria é um gênero neotropical, com ca. 230 espécies (Cabral et al. 2011). Destas,
63 ocorrem no Brasil e 29 na Bahia, estado considerado centro de endemismo para o gênero (Cabral et al. 2011). Na SGLA, Borreria está representada por três espécies, caracterizando-se por serem ervas ou subarbustos com estípulas fimbriadas, inflorescências em glomérulos, frutos capsulares com deiscência longitudinal e sementes com superfície reticulada-foveolada.

\section{Chave para espécies de Borreria}

1. Estípula inteira, ramos glabros Borreria poaya

1'. Estípula 8-fimbriada, fimbrias livres, ramos setosos

2. Lâmina lanceolada, séssil, 3-4,3 cm compr., nervação inconspícua na face adaxial

Borreria capitata

2'. Lâmina elíptica, peciolada, ca. 5,5 cm compr., nervação impressa na superfície adaxial ...

Borreria latifolia

2.1. Borreria capitata DC., Prodr. 4:545. 1830.

Figs. 3c,d; 5a,b

Erva até $1 \mathrm{~m}$ alt. Ramos prostrados cilíndricos, angulares, setosos, esfoliantes. Folhas opostas, sésseis; estípula 8 -fimbriada, setosa, bainha 2,2-2,8 mm compr., fímbrias lineares, ca. $8,8 \times$ $0,6 \mathrm{~mm}$; lâmina lanceolada, ápice agudo, base truncada, $3,0-4,3 \times 0,2-0,6 \mathrm{~cm}$, lisa, cartácea, discolor, setosa. Glomérulo terminal e axilar, séssil; brácteas elípticas, foliares, 1,7-2 ×0,5 cm, verdes, setosas. Flores subsésseis (pedicelo ca. 1 mm compr.); lobos do cálice lanceolados, 2,7-3,1 $\times$ ca. $0,06 \mathrm{~mm}$, verdes, setosos na margem; corola ca. 4,4 mm compr., tubo ca. 2,7 mm compr., alvo, estrigoso externamente, glabro internamente, lobos triangulares, ápice agudo, alvos, estrigosos externamente, papilosos internamente; anteras ca. $1 \times 0,5 \mathrm{~mm}$, azuis, glabras; estilete ca. $5 \mathrm{~mm}$ compr., alvo, glabro, estigma capitado, ca. 0,2 mm compr., papiloso. Fruto 1,2-1,5 mm compr., piloso. Semente oblonga, ca. $2,1 \times 0,5 \mathrm{~mm}$, castanha.

Material examinado: Licínio de Almeida, Saco da Onça, 24.V.2013, 1441'23,7'S, 42³2'35,7'W, fl. e fr., R.L. Borges et al. 151 (ALCB, CEPEC, HUEFS); Trilha para o Cachoeirão, 14.V.2015, 14\%41'3,5"S, 42³2'44,1”W, fl. e fr., R.L. Borges et al. 291 (ALCB, CEPEC, HUEFS).

Borreria capitata é uma espécie amplamente distribuída na América do Sul (Cabral et al. 2011; BFG 2015). Na SGLA, esta espécie está associada sempre a áreas de Cerrado, diferenciando-se das demais por apresentar lâmina foliar $3-4,3 \mathrm{~cm}$ compr. (vs. 4,4-6,9 cm compr.) e anteras azuis (vs. anteras lilás em $B$. poaya).
2.2. Borreria latifolia K.Schum., Fl. bras. 6(6): 61 . 1888.

Fig. 3e,f

Erva ca. $20 \mathrm{~cm}$ alt.. Ramos decumbentes, angulares, estriados, setosos, vináceos. Folhas opostas, pecioladas (pecíolo 1-1,2 cm compr.); estipula 8-fimbriada, setosa, bainha ca. $2 \mathrm{~mm}$ compr., fímbrias linear-triangulares, $6-7 \times$ ca. 0,5 $\mathrm{mm}$; lâmina elíptica, ápice agudo, base decorrente, ca. 5,5 $\times 2,5 \mathrm{~cm}$, lisa, nervuras impressas na face adaxial, membranácea, discolor, setosa. Glomérulo terminal e axilar, séssil; brácteas elípticas, foliáceas, 2,5-3,1 × 1,1-1,4 cm, verdes, setosas. Flores não observadas. Fruto ca. $3 \mathrm{~mm}$ compr., verde, setoso. Semente oblonga, 2-2,3 × 1-1,6 mm, marrom, reticulada-foveolada.

Material examinado: Licínio de Almeida, Garimpo das Ametistas, 14.V.2015, 14³1'55,5'S, 42³2'4,7'W, fr., R.L. Borges et al. 304 (ALCB, CEPEC, HUEFS).

Borreria latifolia é uma espécie de ampla distribuição, ocorrendo em todos os estados do Brasil (com exceção do Rio Grande do Sul), países da América do Sul, África, Ásia e Austrália (Chaw \& Peng 1987). Na SGLA, esta espécie ocorre em áreas de Caatinga antropizada, diferenciando-se das demais por apresentar ramos com indumento setoso-vináceo ( $v s$. indumento setoso-alvo ou glabro), face adaxial da lâmina com nervação impressa ( $v s$. nervação inconspícua).

\subsection{Borreria poaya (A. St.-Hil.) DC., Prodr. 4:549.} 1830.

Figs. 3g-i; 5c-e

Erva ca. $40 \mathrm{~cm}$ alt. Ramos eretos, cilíndricos, estriados, glabros. Folhas opostas, sésseis; estipula inteira, glabra, bainha $3,2-3,8 \mathrm{~mm}$ compr., 

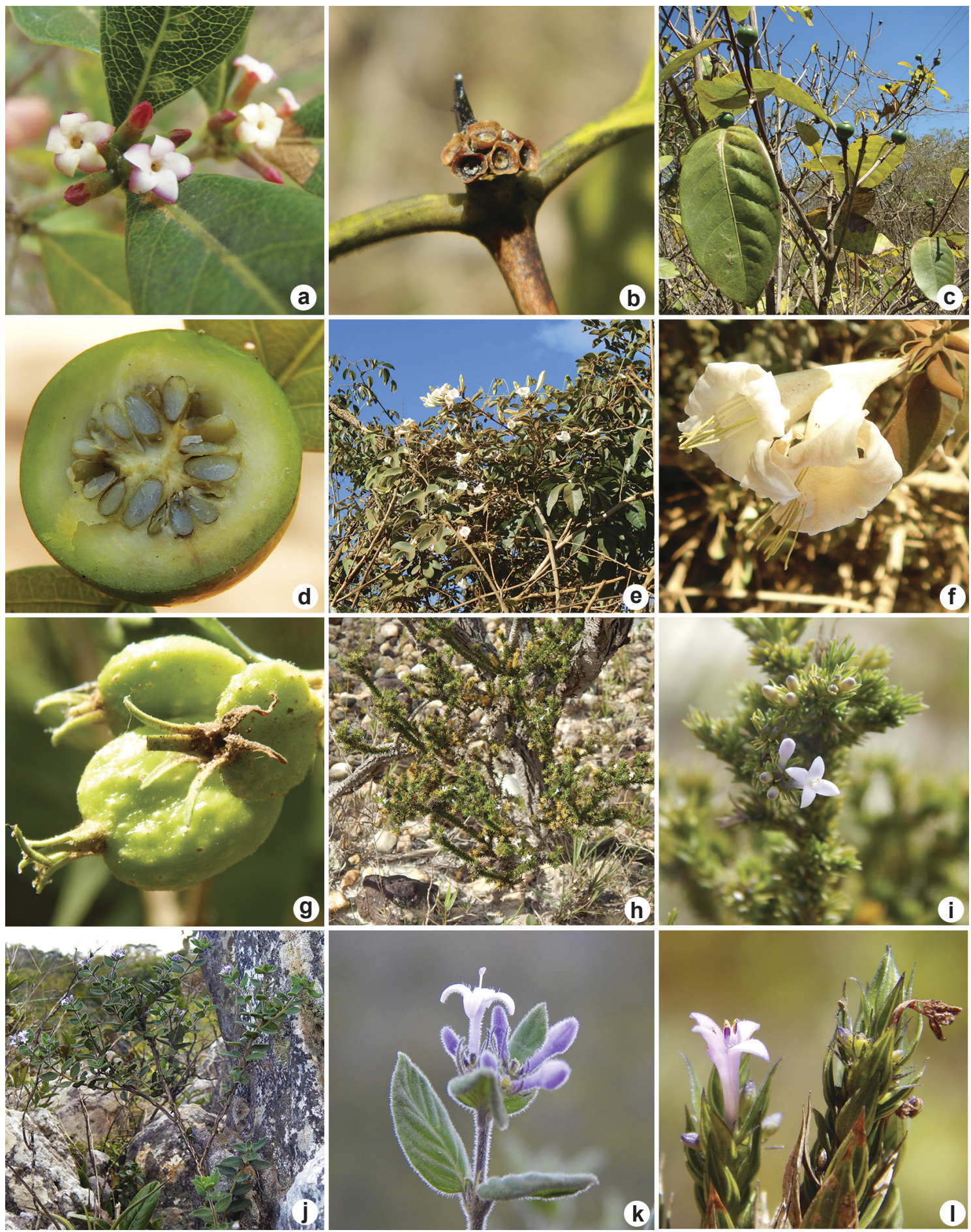

Figura 4 - a. Cordiera elliptica - inflorescência. b-d. Cordiera sessilis - b. inflorescência; c. ramos com frutos; d. fruto bacáceo. e-g. Coutarea hexandra - e. ramos com flores; f. flores; g. fruto capsular imaturo. h,i. Declieuxia aspalathoides - h. hábito; i. inflorescência. j,k. Declieuxia fruticosa - j. hábito; k. inflorescência; 1. Declieuxia passerina - inflorescência. (a,c. N. Roque).

Figure 4 - a. Cordiera elliptica - inflorescence. b-d. Cordiera sessilis - b. inflorescence; c. branches with fruits; d. berry fruit. e-g. Coutarea hexandra - e. flowering branches; f. flowers; g. capsule immature. h,i. Declieuxia aspalathoides - h. habit; i. inflorescence. j,k. Declieuxia fruticosa - j. habit; k. inflorescence; 1. Declieuxia passerina - inflorescence. (a,c. N. Roque). 
6,1-6,2 × 2,8-3,2 mm; lâmina lanceolada, ápice acuminado, base truncada, 4,4-6,9 × 2-2,7 cm, lisa, cartácea, discolor, glabra. Glomérulo terminal ou axilar, séssil; brácteas lanceoladas a ovadas, foliares, 1,2-2,5 × 0,6-1,6 cm, verdes, glabras. Flores subsésseis (pedicelo ca. 0,8 mm compr.); lobos do cálice triangulares, 5,9-6,5 × 1,3-1,6 mm, róseos, glabros; corola 7,9-8,4 mm compr, tubo ca. 5,1 mm compr., lilás, glabro externamente, viloso internamente, lobos da corola triangulares, ápice agudo, lilás, vilosos internamente; anteras ca. $2 \times$ 0,4 mm, lilás, glabras; estilete ca. 5,1 mm compr., alvo, glabro; estigma bífido, lobos do estigma ca. $1 \mathrm{~mm}$ compr., papilosos. Fruto ca. $5 \mathrm{~mm}$ compr., glabro. Semente elipsoide $3 \times 1,5 \mathrm{~mm}$ compr., castanha, reticulada-foveolada.

Material examinado: Licínio de Almeida, Casa de Barro, próximo ao rio, 26.II.2012, 1469'66"S, 42'55'30'W, fl. e fr., F.A. Santana et al. 133 (ALCB); Cascarrento, 21.I.2013, 14³1'13,9”S, 42³3'28,2”W, fl. e fr., R.L. Borges et al. 080 (ALCB, CEPEC, HUEFS); Mata do Riacho de Areia, 20.I.2015, 1446'54,7"S, 42³4'4,9'W, fl. e fr., R.L. Borges et al. 225 (ALCB, CEPEC, HUEFS).

Borreria poaya é uma espécie típica de Cerrado, ocorrendo predominantemente ao longo das regiões Centro-Oeste, Sudeste e Sul do Brasil (BFG 2015). Na Bahia esta espécie ocorre principalmente na região Sudoeste, próximo à divisa com Minas Gerais (Cabral et al. 2011). Na SGLA, ocorre em campos rupestres e cerrado sensu stricto, diferenciando-se das demais por apresentar ramos cilíndricos, glabros (vs. ramos costados, setosos), estípula inteira ( $v s$. estípula fimbriada) e flores lilases (vs. flores alvas).

3. Chiococca P. Browne, Civ. Nat. Hist. Jam. 164. 1976.

Arbustos, arvoreta ou lianas. Ramos prostrados, cilíndricos, eretos ou decumbentes. Folhas opostas, pecioladas; estípula inteira; lâmina foliar elíptica a ovada. Inflorescência em racemo, axilar, pedunculada. Flores pediceladas; cálice 4-5 lobado; corola 4-5 lobada, campanulada ou tubular; estames inseridos na base da corola, filetes formando um tubo, anteras ovadas; ovário 2-locular, um óvulo por lóculo, estigma capitado ou bífido. Fruto bacáceo, subgloboso, verde-vináceo a alvo. Semente subglobosa, compressa.

Chiococca é um gênero neotropical, apresentando ca. 22 espécies, distribuídas do sul dos Estados Unidos ao sul do Brasil (Mendaçolli 2007). No Brasil são encontradas quatro espécies, associadas a diversos domínios fitogeográficos e formações vegetais (BFG 2015). Este gênero caracteriza-se por apresentar inflorescências em racemos, flores campanuladas e frutos bacáceos alvos quando maduros.

3.1. Chiococca alba Hitch., Rep. Missouri Bot. Gard. 4: 94. 1893.

Figs. 3j,k; $5 \mathrm{f}$

Arbusto ca. $2 \mathrm{~m}$ alt. Ramos eretos ou escandentes, estriados, puberulentos a glabrescentes. Folhas pecioladas (pecíolo 1,4-2,6 mm compr.); estípula amplamente triangular, 1,5-1,7 × 2,1-2,5 mm, puberulenta; lâmina elíptico-ovada, ápice agudo, base cuneada, 3,3-4 × 1,2-2,4 cm, lisa, cartácea, discolor, glabra. Inflorescência pedunculada (pedúnculo 0,6-1 cm compr.); brácteas estreitamente triangulares, ca. $3 \times 0,5$ $\mathrm{mm}$, creme-ferrugíneas, setosas. Flores pediceladas (pedicelo 2-2,5 mm compr.); cálice 5-lobado, lobos do cálice deltados, ca. 0,5 × 0,5 mm, vináceos, glabros; corola 5-lobada, campanulada, 4-4,5 mm compr., tubo 2-2,5 mm compr., róseo, glabro, lobos triangulares, ápice agudo, roseos, glabros; anteras ca. 2,5 $\times 0,4 \mathrm{~mm}$, amarelas, glabras; estilete ca. $3 \mathrm{~mm}$ compr., creme, estigma capitado ca. 3 $\mathrm{mm}$, papiloso. Fruto imaturo, 3,5-4 × 4-4,1 mm, glabro. Semente elipsoide, aplainada, ca. $3 \times 2 \mathrm{~mm}$, castanha, lisa.

Material examinado: Licínio de Almeida, Cascarrento, 21.I.2013, fl. e fr., 14'33'13,9”'S, 42'33'28,2”W, R.L. Borges et al. 81 (ALCB, CEPEC, HUEFS); Santa Clara, 25.V.2013, fl. e fr., 1429'52,1'S, 42³2'44,8”W, R.L. Borges et al. 161 (ALCB, HUEFS); Estrada para Riacho de Areia, 20.I.2015, fl., 1445'32,5”'S, 42³4'38,3”W, R.L. Borges et al. 210 (ALCB, CEPEC, HUEFS).

Material adicional examinado: Licínio de Almeida, $3 \mathrm{~km}$ antes da entrada da cidade, fl., T.S. Nunes 1662 (HUEFS).

Chiococca alba é uma espécie amplamente distribuída, ocorrendo em diversas fitofisionomias (BFG 2015). Na SGLA, C. alba ocorre em área de cerrado stricto sensu, caracterizando-se por apresentar inflorescências axilares e flores campanuladas alvas a róseas.

4. Chomelia Jacq., Enum. Syst. P1. 1: 12. 176.

Arbustos ou árvores. Ramos eretos, espinescentes ou inermes, cilíndricos ou costados. Folhas opostas, pecioladas a subsésseis, podendo estar reunida no ápice dos ramos; estípula inteira; lâmina elíptica ou lanceolada. Inflorescência axilar ou terminal, pedunculada. Flores pediceladas ou sésseis; cálice 4 lobado; corola 4-lobada, hipocrateriforme; ovário 2-locular, um óvulo por lóculo, estigma bífido. Fruto carnoso, drupáceo, elipsoide. Semente elipsoide. 


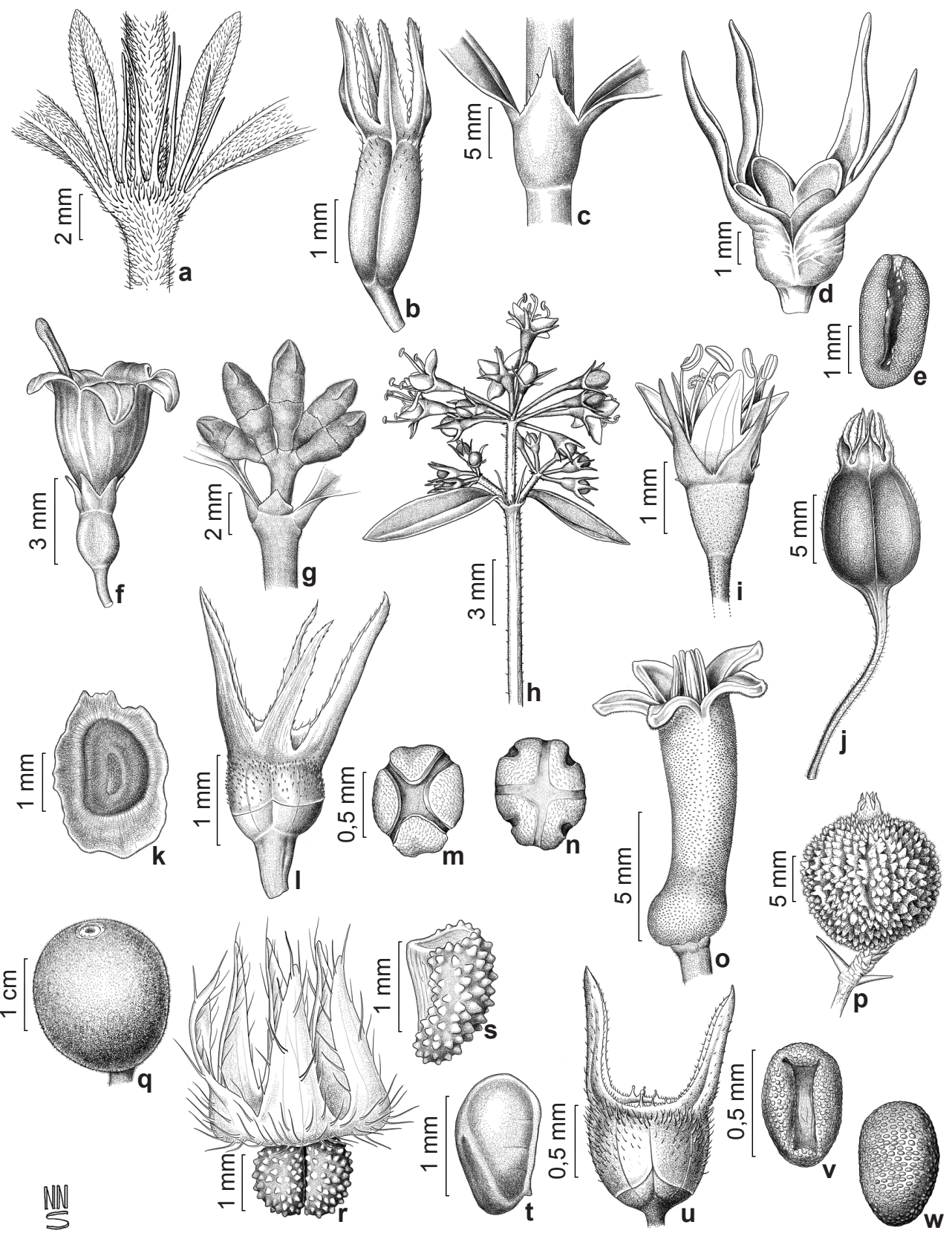

Figura 5 - a,b. Borreria capitata - a. estípula fimbriada; b. fruto cápsula. c-e. Borreria poaya - c. estípula; d. fruto cápsula; e. superfície ventral da semente com cicatriz longitudinal. f. Chiococca alba-corola campanulada. g. Cordiera ellipticaglomérulo. h,i. Emmeorhiza umbellata - h. inflorescência; i. flor com corola sub-rotacea.j,k. Manettia cordifolia-j. fruto; k. semente alada. 1-n. Mitracarpus baturitensis - 1. fruto capsular com deiscência circuncisa; m. semente (face ventral); $\mathrm{n}$. semente (face dorsal). o. Palicourea rigida - corola gibosa. p. Randia sp. nov - fruto muricado. q. Randia calycina - fruto liso. r-t. Richardia grandifolia - r. fruto esquizocárpico e cálice 6-lobado; s. mericarpo papiloso; t. semente. u-w. Staelia sp. - u. fruto com deiscência transversal obliqua; v. semente (face ventral); w. semente (face dorsal).

Figure 5 - a,b. Borreria capitata - a. fimbriate stipule; b. capsular fruit. c-e. Borreria poaya - c. stipule; d. capsular fruit; e. ventral surface of seed with longitudinal scar. f. Chiococca alba - campanulate corolla. g. Cordiera elliptica - glomerule. h,i. Emmeorhiza umbellata - h. inflorescence; i. flower with subrotaceous corolla. j,k. Manettia cordifolia - j. fruit; k. wing seed. 1-n. Mitracarpus baturitensis - 1. capsule with dehiscence circumcises; $\mathrm{m}$. seed (ventral surface); n. seed (dorsal surface). o. Palicourea rigida - gibbose corolla. p. Randia sp. nov muricate fruit. q. Randia calycina - smooth fruit. r-t. Richardia grandifolia - r. schizocarpic fruit with six lobed calyx; s. papillous mericarp; t. seed. u-w. Staelia sp. - u. fruit with transversal oblique dehiscence; v. seed (ventral surface); w. seed (dorsal surface). 
Chomelia é um gênero com ca. 160 espécies, 70 neotropicais, das quais 37 ocorrem no Brasil (Barbosa 2007; BFG 2015). Este gênero caracterizase por apresentar ramos caulinares modificados em espinhos; flores 4-lobadas e frutos drupáceos oblongos a elipsoides.

4.1. Chomelia obtusa Cham. \& Schltdl., Linnea 4: 185. 1829.

Fig. 31

Árvore 3-4 m alt. Ramos estriados, espinescentes, lenticelados, glabros. Folhas (pecíolo ca. 1,3 mm compr.); estipula triangular, $1 \times 1,3$ $\mathrm{mm}$, setosa; lâmina elíptica, ápice arredondado a obcordado, base atenuada, 2,9-3,3 × 1,5-1,6 cm, lisa, cartácea, discolor, glabra. Inflorescência em dicásios, axilares ou terminais, pedunculada (pedúnculo ca. $0,8-1 \mathrm{~cm}$ compr.); brácteas estreitamente triangulares, ca. $0,8 \times 0,3 \mathrm{~mm}$, ferrugíneas, seríceas. Flores sésseis; lobos do cálice triangulares, ca. $1 \times 1 \mathrm{~mm}$, ferrugíneos, seríceos; corola ca. 1,3 cm compr., tubo ca. $1,1 \mathrm{~cm}$ compr., vináceo, seríceo externamente, glabro internamente, lobos triangulares, ca. 1,7 × 1,7 mm, ápice agudo, cremes a vináceos, seríceos externamente, glabros internamente; anteras estreitamente oblongas, ca. 1,6 $\times 0,6 \mathrm{~mm}$, alvas, glabras; estilete ca. $5,4 \mathrm{~mm}$ compr., creme, glabro, lobos do estigma ca. $1 \mathrm{~mm}$ compr., glabros. Fruto ca. $6,3 \times 4,4 \mathrm{~mm}$, verde a atropurpúreo, sericeo. Semente $6 \times 4 \mathrm{~mm}$, creme, lisa.

Material examinado: Licínio de Almeida, Lameirão, 6.IV.2013, fl. e fr., 1441'23,7'S, 42³2'35,7'W, R.L. Borges et al. 121 (ALCB); Subida para Riacho de Areia, 20.I.2015, fl. e fr., $14^{\circ} 45^{\prime} 32,5^{\prime \prime}$ 'S, 42³4'38,3”'W, R.L. Borges et al. 213 (ALCB, CEPEC, HUEFS); São Domingos de Baixo, 22.I.2015, fl. e fr,14²7'21,5”'S, $42^{\circ} 31^{\prime}$ '”'W, R.L. Borges et al. 261 (ALCB, CEPEC, HUEFS).
Chomelia obtusa é uma espécie amplamente distribuída, ocorrendo em diversos domínios fitogeográficos brasileiros e associada a formações vegetais de floresta estacional e floresta ombrófila (BFG 2015). Chomelia obtusa caracteriza-se por apresentar flores vináceas com indumento seríceo e fruto atropurpúreo quando maduro. Na SGLA, $C$. obtusa está associada a florestas estacionais.

5. Cordiera A. Rich. ex DC., Prodr. 4: 445. 1830.

Arbustos ou árvores. Ramos eretos, cilíndricos. Folhas opostas, pecioladas; estípula inteira; lâmina foliar elíptic. Inflorescência masculina em glomérulo, feminina uniflora. Flores unissexuais, sésseis a pediceladas; cálice 4-5 lobado, lobos fusionados em estrutura cupuliforme; corola 4-5 lobada, hipocrateriforme; anteras oblongas; flores masculinas com anteras férteis; flores femininas com anteras estéreis, ovário 2-5 locular, lóculos pluriovulados, estigma em mesmo número de lóculos do ovário, fértil. Fruto bacáceo, globoso, verde a atropurpúreo quando maduro. Semente compressa, suborbicular.

Cordiera é um gênero neotropical distribuindo-se da Costa Rica ao Sul do Brasil com ca. 23 espécies (Persson \& Delprete 2010). No Brasil, são encontradas dez espécies para o gênero, associadas a diversos domínios fitogeográficos e formações vegetais (BFG 2015). Este gênero caracteriza-se por apresentar flores unissexuais, as masculinas agrupadas em glomérulos (Fig. 3g) e as femininas em inflorescência uniflora; cálice cupuliforme e frutos bacáceos com muitas sementes, suborbiculares. Na SGLA são encontradas três espécies, associadas a cerrado sensu stricto campos rupestre e floresta estacional.

\section{Chave de identificação das espécies de Cordiera}

1. Lâmina foliar 10,6-11,6 cm compr., folha sem domacias, fruto 1-2,2 cm compr....... Cordiera sessilis

1'. Lâmina foliar 2,2-4,9 cm compr., folha apresentando domacias, fruto $0,5-0,8 \mathrm{~cm}$ compr................. 2

2. Lâmina foliar 3,5-4,9 cm compr.; lobos da corola creme-lilases .......................Cordiera elliptica

2'. Lâmina foliar 2,2-2,9 cm compr.; lobos da corola alvos a ferrugíneos .................. Cordiera rigida

5.1. Cordiera elliptica Kuntze, Rev. Gen. Pl. 1: 279. 1891. Figs. $4 \mathrm{a} ; 5 \mathrm{~g}$

Arbusto ca. 1,5 m alt.. Ramos eretos, cilíndricos, estriados, esfoliantes, puberulentos a glabrescentes. Folhas pecioladas (pecíolo 1,4-2,8 $\mathrm{mm}$ compr.); estípula triangular, 1,7-3,8 $\times 1,7$ $2,9 \mathrm{~mm}$, puberulenta; lâmina elíptica, ápice agudo a arredondado, base atenuada, 3,5-4,9 × 2,2-3,1 $\mathrm{cm}$, lisa, cartácea, discolor, glabra, domacias na face abaxial. Glomérulos terminais, subsésseis (pedúnculo ca. 0,5 mm compr.), puberulentos; brácteas circulares, ca. 0,5 mm compr., verdes, glabras. Flores masculinas sésseis, cálice ca. 1 $\mathrm{mm}$ compr., puberulento; corola 3,2-4,2 $\mathrm{mm}$ 

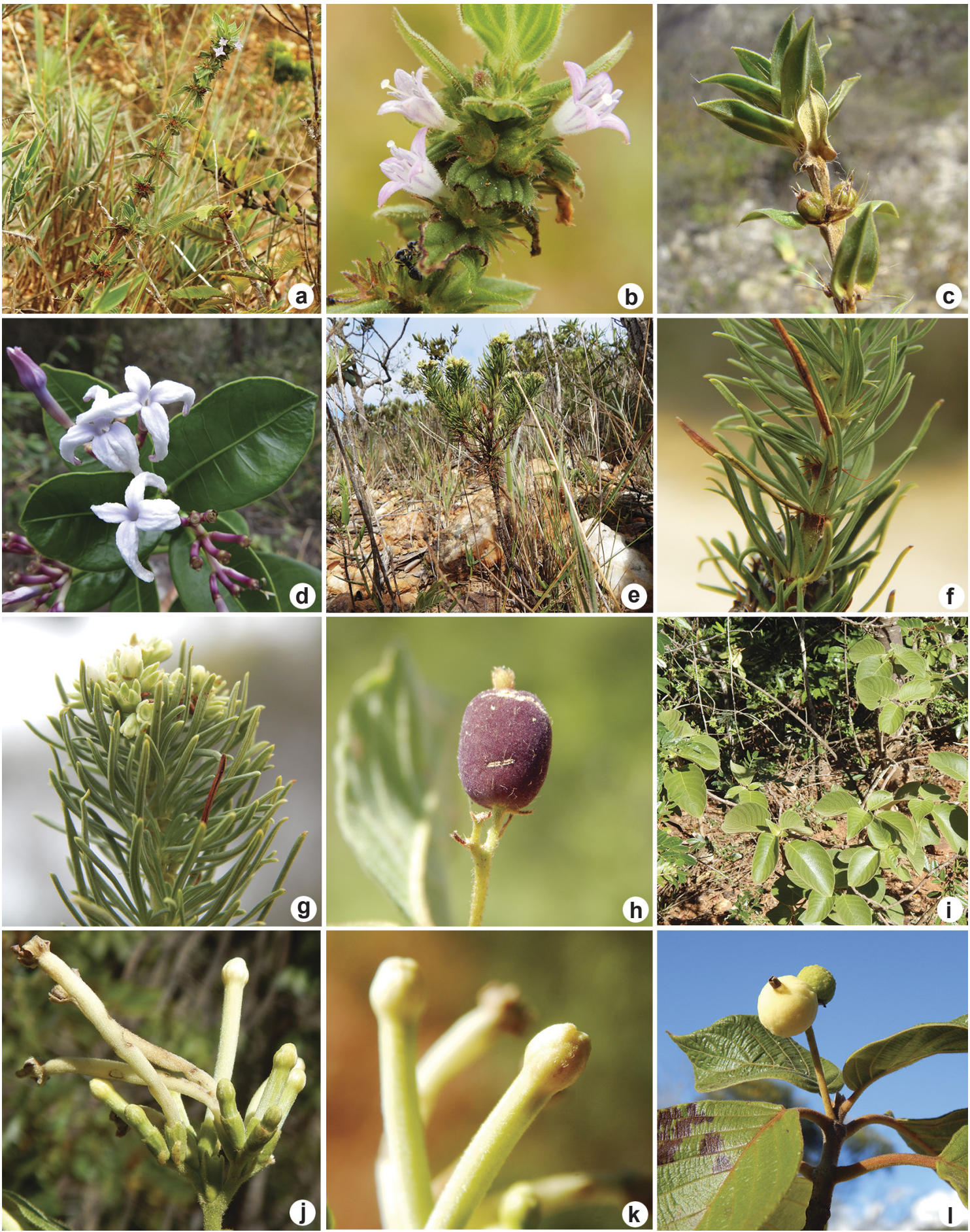

Figura 6 -a,b. Hexasepalum radulum - a. hábito; b. glomérulo. c. Hexasepalum teres - folhas lanceoladas e glomérulo. d. Faramea nigrescens - flores. e-g. Galianthe peruviana - e. hábito; f. folhas lineares, dispostas em fascículos; g. inflorescência. h. Guettarda sericea - fruto. i-l. Guettarda viburnoides - i. hábito; j. Inflorescência; k. flores; 1. fruto globoso. (c. N. Roque; d. J. Coelho).

Figure 6 - a,b. Hexasepalum radula - a. habit; b. glomerule. c. Hexasepalum teres - lanceolate leaves and glomerule. d. Faramea nigrescens - flowers. e-g. Galianthe peruviana - e. habit; f. linear leaves arranged in fascicles; g. inflorescence. h. Guettarda sericea fruit. i-1. Guettarda viburnoides - i. habit; j. inflorescence; k. flowers; 1. globose fruits. (c. N. Roque; d. J. Coelho). 
compr., tubo ca. 2,5 mm compr., creme, seríceo externamente, glabro internamente, lobos triangulares, ápice agudo, cremes, lilases na margem, seríceos externamente, tomentosos internamente; anteras 2,2-2,7 × 0,6-0,7 mm, glabras; estilete ca. 2,1 mm compr., creme, glabro. Flores femininas não observadas. Fruto $6,7-8,1 \times 6,7-7 \mathrm{~mm}$, puberulento. Semente ca. $3,6 \times 2,4 \mathrm{~mm}$, creme, superfície linear.

Material examinado: Licínio de Almeida, Fazenda Riacho de Areia, 22.I.2013, fl., 1441'33,2"S, 42'34'38,8"W, R.L. Borges et al. 77 (ALCB, CEPEC); Fazenda Santa Clara, 25.V.2013, fl., 14'29'52,1"S, 42³2'44,8”W, R.L. Borges et al. 160 (ALCB, CEPEC, HUEFS).

Material adicional examinado: Caetité, Trilha para Brejinho das Ametistas, fr., 144'49'S, 42³0'50"W, A.M. de Carvalho et al. 6247 (CEPEC).

Cordiera elliptica é uma espécie endêmica do Brasil, ocorrendo nos domínios Amazônico, Caatinga e Cerrado (BFG 2015). Na SGLA, esta espécie está associada a áreas de Cerrado e margem de florestas estacionais, diferenciandose das demais espécies por apresentar flores masculinas com lobos da corola creme-lilases (vs. lobos alvos) e lâmina foliar 3,5-4,9 cm compr. (vs. 2,2-2,9 cm compr. em C. rigida e 10,6-11,6 cm compr. em C. sessilis).

5.2. Cordiera rigida Kuntze, Revis. Gen. Pl. 1: 279.1891.

Arbusto 0,7-2 m alt.. Ramos cilíndricos, estriados, esfoliantes, escabros a glabrescentes. Folhas pecioladas (pecíolo 1,7-3,1 mm compr.); estípula triangular, aristada, 1,2-2,7 × 1,6-2 mm compr., escabrida; lâmina elíptica, ápice arredondado, base decorrente, 2,2-2,9 × 1-1,4 $\mathrm{cm}$, lisa, coriácea, discolor, glabra adaxialmente, puberulenta abaxialmente, domacias na face abaxial. Glomérulo terminal, pedunculado (pedúnculo ca. 1,5 $\mathrm{mm}$ compr.); brácteas circulares, ca. 0,4-0,8 mm compr., cremes a ferrugíneas, glabras. Flores masculinas sésseis; cálice 0,6-1 mm compr., creme-esverdeado, glabro; corola ca. 6,2 mm compr., tubo 4,4-4,7 mm compr., alvo a ferrugíneo, puberulento a glabrescente, lobos triangulares, ápice agudo, alvos a ferrugíneos, puberulentos; anteras ca. $2,8 \times 0,5 \mathrm{~mm}$, amarelas a amarronzadas, glabras. Flores femininas não observadas. Fruto 5-6,5 $\times$ 5,5-7,4 mm, glabro. Semente ca. 3,8 × 2,9 $\mathrm{mm}$, amarela a amarronzada, superfície linear. Material examinado: Licínio de Almeida, Estrada para Caetité, 3.XI.2006, fr., 1466'64”S, 4251'33”W,
R.F. Souza 219 (HUEFS); Cascarrento, 19.VII.2012, fl., 1433'14"S, 42³3'28'W, R.L. Borges et al. 62 (ALCB, HUEFS); Pedra preta, 27.X.2012, fr., 14'45'6"S, 42³2'40"W, N. Roque et al 3772 (ALCB). Cachoeira das Sete Quedas, 5.XI.2013, fr., 14³7'42,2”S, 42³0'39,9'W, R.L. Borges et al. 173 (ALCB. CEPEC, HUEFS).

Cordiera rigida é uma espécie endêmica do Brasil, ocorrendo nos domínios da Caatinga e Cerrado, nas fitofisionomias de cerrado stricto sensu, campo rupestre, carrasco, floresta estacional e vegetação sobre afloramento rochoso (BFG 2015). Na SGLA, a espécie está associada a fitofisionomia de cerrado stricto sensu, diferenciando-se das demais por apresentar lâmina foliar 2,2-2,9 cm compr ( $v s$. 3,5-4,9 cm compr. em C. elliptica e 10,6-11,6 cm compr. em $C$. sessilis).

5.3. Cordiera sessilis Kuntze, Revis. Gen. Pl. 1: 279.1891 .

Fig. 4b-d

Arbusto ca. $4 \mathrm{~m}$ alt.. Ramos cilíndricos, estriados, esfoliantes, glabros. Folhas pecioladas (pecíolo 0,4-1 cm); estípula triangular a largamente triangular, 3,8-4,9 × 2,7-6,5 mm, glabra; lâmina elíptica, ápice acuminado, base atenuada, 10-11,6 × 5-6 cm, lisa, coriácea, discolor, glabra, domácias ausentes. Glomérulos terminais, sésseis, glabros; brácteas circulares ca. 2,1 mm compr., verdes, glabras. Flores masculinas, sésseis; cálice ca. $1 \mathrm{~mm}$ compr., verde, glabro; corola 4,7-5,6 $\mathrm{mm}$ compr., tubo 3,2-3,7 mm compr., verde, glabro, lobos ovados, ápice arredondado, alvos, glabros; anteras ca. $3 \times 0,6 \mathrm{~mm}$, alvas, glabras; estilete ca. $4 \mathrm{~mm}$ compr., alvo, glabro. Flores femininas não observadas. Fruto $1-2,2 \times 1,1-2,2 \mathrm{~cm}$, glabro. Semente ca. 4-4,7 × 3,5-4,9 mm, castanha, superfície linear a lisa.

Material examinado: Licínio de Almeida, Trilha para Cachoeirão, 20.VII.2012, fr., 1441'20,1'S, 42`32'34,3”W, R.L. Borges et al. 68 (ALCB, CEPEC); São Domingos de baixo, 22.I.2015, fr.,14²7'21,5'S, 42'31'6”W, R.L. Borges et al. 263 (ALCB).

Cordiera sessilis é uma espécie amplamente distribuída, ocorrendo nos domínios da Caatinga e Cerrado, nas fitofisionomias de floresta estacional e cerrado stricto sensu (BFG 2015). $\mathrm{Na}$ SGLA, C. sessilis está associada apenas a áreas de floresta estacional e diferencia-se das demais espécies por apresentar superfície foliar abaxial sem domacias ( $v s$. presença de domacias) e frutos robustos (1,1-2,2 cm compr. vs. $0,5-0,8 \mathrm{~cm}$ compr.). 

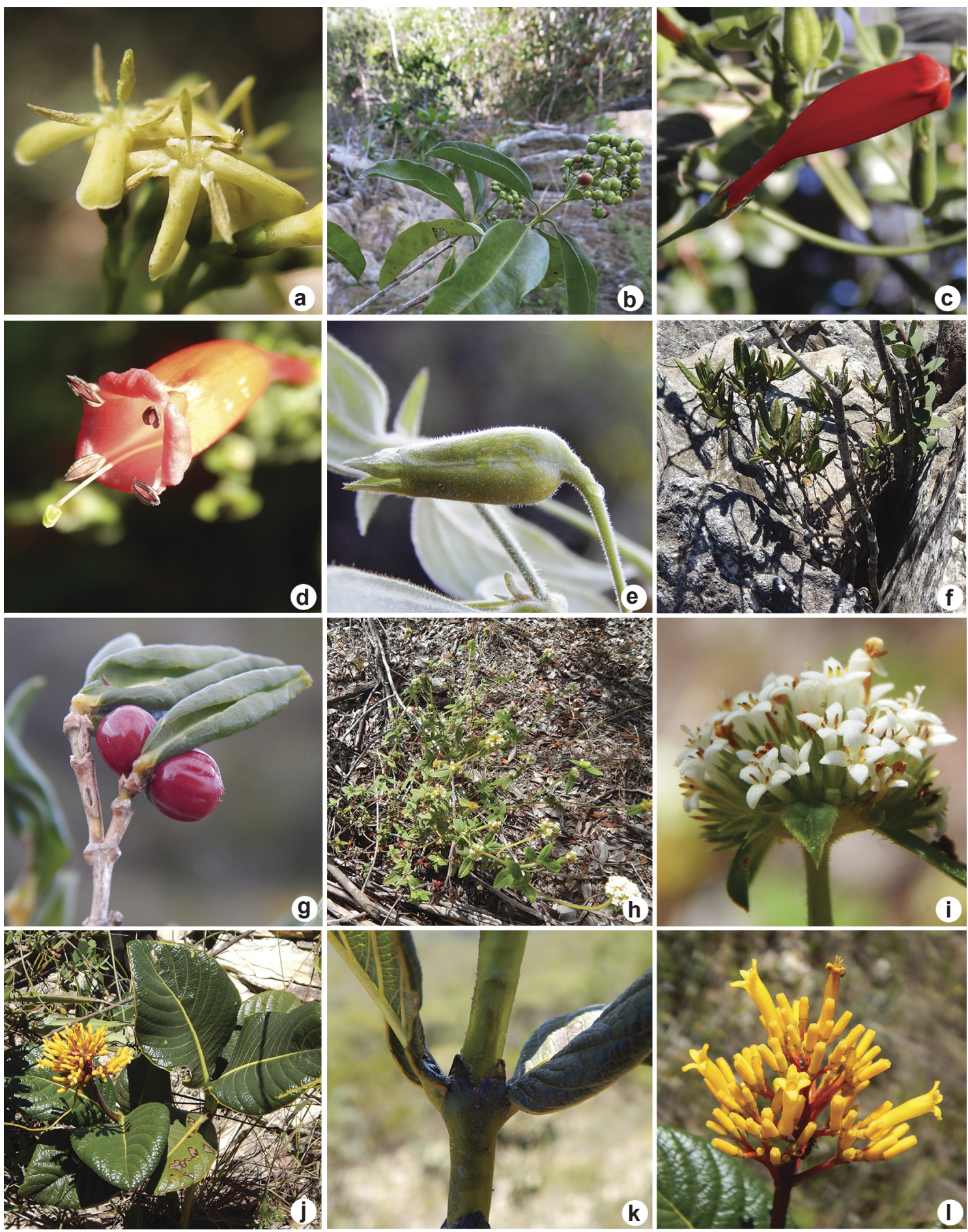

Figura 7 - a,b. Ixora brevifolia - a. flores; b. frutos. c-e. Manettia cordifolia - c,d. flores; e. fruto. f,g. Margaritopsis carrascoana - f. hábito; g. fruto. h,i. Mitracarpus baturitensis - h. hábito; i. glomérulo. j,k. Palicourea rigida - j. hábito; k. estípula bífida; 1. inflorescência. (a. A. Stadnik; b. F. Hurbath).

Figure 7 - a,b. Ixora brevifolia - a. flowers; b. fruits. c-e. Manettia cordifolia - c,d. flowers; e. fruit. f,g. Margaritopsis carrascoana f. habit; g. fruit. h,i. Mitracarpus baturitensis - h. habit; i. glomerule. j,k. Palicourea rigida - j. habit; k. bifid stipule; 1. inflorescence. (a. A. Stadnik; b. F. Hurbath). 
6. Coussarea Aubl., Hist. Pl. Guiane 1: 98. 1775. Arbusto ou árvores de médio porte. Ramos cilíndricos ou aplainados. Folhas opostas ou verticiladas, pecioladas ou sésseis; estípula inteira, ápice agudo; lâmina foliar elíptica, lanceolada, oblonga, obovada ou ovada. Inflorescência em panícula, tirso ou capituliforme, terminal. Flores sésseis ou pediceladas, cálice 4-lobado, corola 4-lobada, infundibuliforme ou hipocrateriforme, antera oblonga ou linear; ovário bilocular, um óvulo por lóculo, estigma bífido. Fruto carnoso, drupáceo, castanho a vináceo. Semente elipsoide, obovóide a subglobosa.

Coussarea é um gênero neotropical, compreendendo ca. 115 espécies, das quais ca. 56 ocorrem no Brasil, habitando ambientes úmidos e sombreados (Pereira 2007; BFG 2015). Coussarea é filogeneticamente relacionado a Faramea, caracterizando-se por apresentar estípulas triangulares caducas (não aristadas), e inflorescência capituliforme ou em panícula, congesta (Pereira 2007).

6.1. Coussarea capitata (Benth.) Mull. Arg., Flora 58(30): 468. 1875.

Árvore ca. $3 \mathrm{~m}$ alt. Ramos cilíndricos, estriados, puberulentos. Folhas pecioladas (pecíolo 3-4,7 mm compr.); estípula deltada, ca. 1,9 × $2 \mathrm{~mm}$, glabra; lâmina elíptica, ápice acuminado, base decorrente, 5,7-6,9 × 1,9-3,2 $\mathrm{cm}$, lisa, cartácea, discolor, glabra. Inflorescência capituliforme, pedunculada (pedúnculo 0,7-1,2 cm compr.); brácteas inconspícuas. Flores passadas, sésseis; lobos do cálice largamente triangulares, 0,3-0,4 × 0,6-0,8 mm, verdes, glabros; corola hipocrateriforme, $1-1,5 \mathrm{~cm}$ compr., tubo $0,7-0,9$ cm compr., alvo, glabro, lobos triangulares, ápice agudo, alvos, papilosos internamente, glabros externamente. Fruto elipsoide, compresso lateralmente, $1-1,1 \times \mathrm{ca}$. 0,9 cm, atropurpúreo a castanho, liso, glabro. Semente obovóide, ca. 5,2 $\times 5,6 \mathrm{~mm}$, ocre.

Material examinado: Licínio de Almeida, Mata estacional do Xaxá, 21.I.2014, fl., 14³9'1”S, 42³2'40,3"W, R.L. Borges et al. 249 (ALCB, CEPEC, HUEFS); Mata estacional do Xaxá, 12.V.2015, fl., 14³9'1'S, 42³2'40,3”W, R.L. Borges et al. 281 (HUEFS).

Material adicional examinado: BRASIL. RIO DE JANEIRO: Armação de Búzios, 19.VI.1997, fr., A. Lobão et al. 261 (RB, SPF); São Pedro da Aldeia, 3.XII.2001, fl., C. Farney et al. 4433 (RB, SPF).

Coussarea capitata é uma espécie endêmica do domínio Atlântico, estando associada a áreas de floresta ombrófila na Bahia, Ceará e Rio de Janeiro (BFG 2015). Em revisão para Coussarea, Pereira (2007) indica a ocorrência desta espécie para matas em Jequié, e florestas estacionais da Chapada Diamantina. Coussarea capitata caracteriza-se por apresentar estípula triangular, não aristada, inflorescência capituliforme, brácteas inconspícuas e frutos elipsoides, compressos lateralmente. Na SGLA, C. capitata está associada a áreas de floresta estacional.

7. Coutarea Aubl., P1. Gui. 1: 314. 1775.

Arbusto ou árvores de pequeno porte. Ramos cilíndricos. Folhas opostas, pecioladas; estípula inteira; lâmina foliar elíptica a ovada. Inflorescência em corimbo ou panícula, terminal, pedunculada. Flores pediceladas; cálice 6-lobado; corola 6-lobada, infundibuliforme; anteras lineares; ovário 2-locular, muitos óvulos por lóculo, estigma bífido. Fruto seco, capsular, loculicida, ovóide a elipsoide, compresso lateralmente. Semente alada.

Coutarea é um gênero neotropical, compreendendo ca. cinco espécies (Govaerts et al. 2016). No Brasil está representada por uma única espécie (Coutarea hexandra), ocorrendo nos domínios Amazônico, Atlântico, Caatinga e Cerrado (BFG 2015). Este gênero caracteriza-se por apresentar flores com corola alva a rósea, fruto capsular ovóide a elipsoide e sementes aladas.

7.1. Coutarea hexandra (Jacq.) K.Schum., Fl. bras. 6(6): 196. 1889.

Fig. $4 \mathrm{e}-\mathrm{g}$

Árvores ca. $4 \mathrm{~m}$ alt. Ramos cilíndricos, estriados, lenticelados, glabros. Folhas pecioladas (pecíolo 1,3-5,6 mm compr.); estípula deltada, 1-1,6 × ca. 1,7 mm, estrigosa; lâmina elíptica, ápice agudo, base atenuada, 1,1-2,7 × 2,5-5,1 cm, lisa, cartácea, discolor, setosa. Panícula terminal, pedunculada (pedúnculo 1,3-4,5 cm compr.); brácteas lineares, $3,1-5 \times 0,3-0,6 \mathrm{~mm}$, verdes, estrigosas. Flores pediceladas (pedicelo 0,1-1 cm compr.); lobos do cálice lanceolados, ca. $6 \times 1 \mathrm{~mm}$, verdes, estrigosos; corola ca. 5,0 cm compr., tubo ca. 4-4,6 cm compr., creme, piloso externamente, glabro internamente, lobos ovados, ápice agudo, alvos, pilosos externamente, glabros internamente; anteras ca. $9 \times 1 \mathrm{~mm}$, amarelas, glabras; estilete ca. 2,1 cm compr., verde, lobos do estigma ca. $1 \mathrm{~mm}$ compr. Fruto elipsoide, ca. 1,8 × 1,2 cm, verde a ferrugíneo, lenticelado, piloso. Semente ca. 7,7 $\times$ 4,8 mm, ferrugínea.

Material examinado: Licínio de Almeida, Rodovia Licínio de Almeida-Urandi, 31.III.2001, fr., 1442’47’S, 


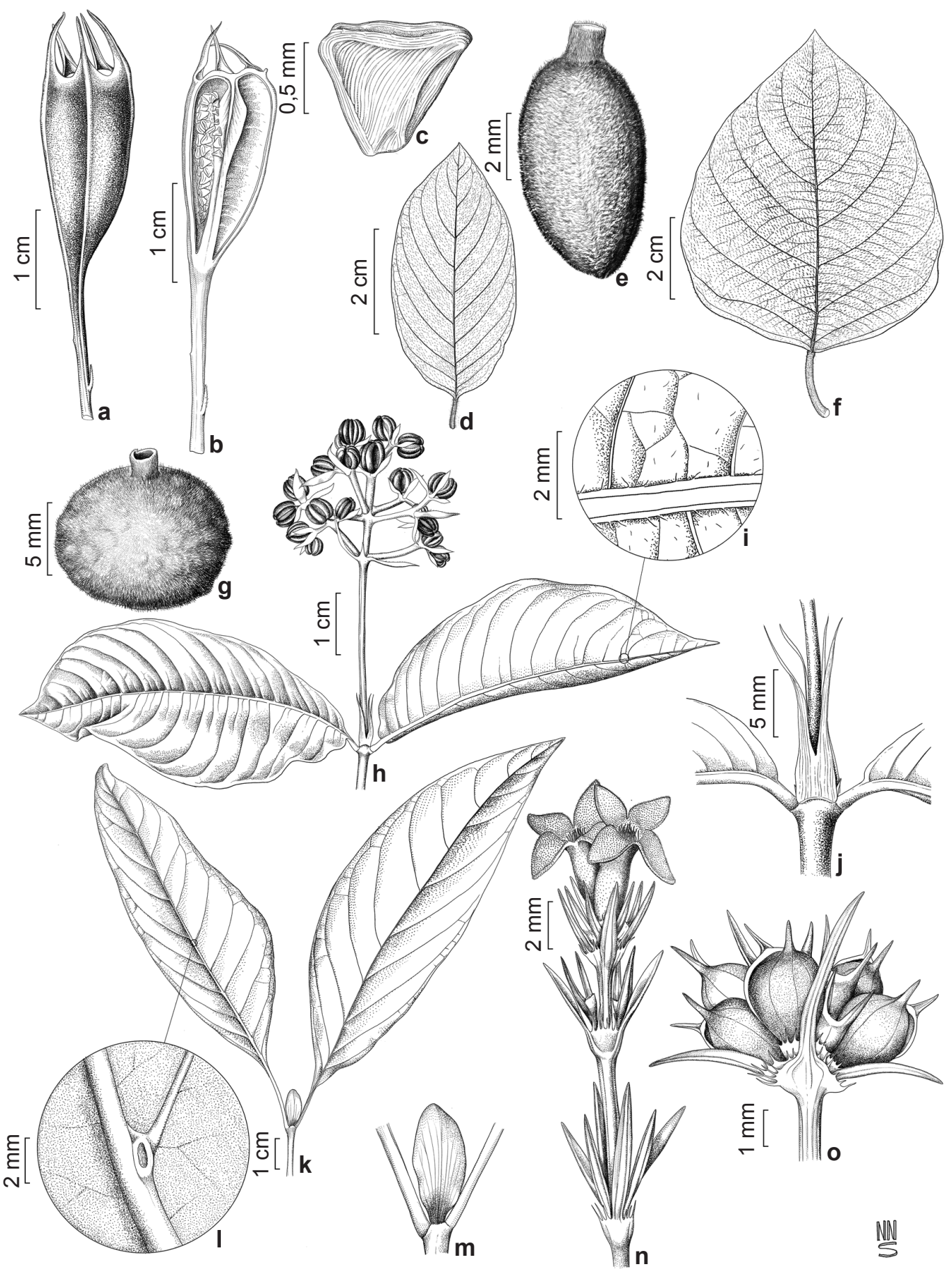

Figura 8 - a-c. Augusta longifolia - a. cápsula; b. corte longitudinal evidenciando fruto com muitas sementes; c. semente obcônica. d,e. Guettarda sericea - d. lâmina foliar elíptica; e. drupa elipsoide. f,g. Guettarda viburnoides - f. lâmina foliar ovada; g. fruto globoso. h-j. Psychotria capitata - h. ramo com folhas e frutos; i. face abaxial com nervura pilosa; j. estípula bífida; k-m. Psychotria mapourioides - k. ramo com folha e estípula; 1. superfície abaxial com domacias; m. estípula inteira, elíptica. n. Psyllocarpus laricoides - inflorescência. o. Psyllocarpus asparagoides - inflorescência. Figure 8 - a-c. Augusta longifolia - a. capsule fruit; b. longitudinal section showing the fruit with many seeds; c. obconic seeds. d,e. Guettarda sericea - d. elliptic blade; e. ellipsoid drupe. f,g. Guettarda viburnoides - f. ovate blade; g. globose fruit. h-j Psychotria capitata - h. branches with fruits; i. abaxial surface with pilose vein; j. bifid stipule; k-m. Psychotria mapourioides - k. branch with leaves and stipule; 1 . abaxial surface with domatia; m. entire stipule, elliptic. n. Psyllocarpus laricoides - inflorescence. o. Psyllocarpus asparagoides - inflorescence. 
42³0'33”W, J.G. Jardim et al. 3305 (ALCB, CEPEC, HUEFS); Fazenda São Domingos, 10.XII.2009, fl., 14'27'05'S, 42³1'30”W, M.L. Guedes et al. 16740 (ALCB, HUEFS); São Domingos 10.XII.2009, fl. e fr., 1446'38,8'S, 4251'30,5'W, M.L. Guedes et al. 16805 (ALCB, HUEFS); Estrada para o Saco da Onça, 20.I.2015, fl., 14³5'S, 42³1'35,2'W, R.L. Borges et al. 209 (ALCB, CEPEC, HUEFS); Estrada Jurema para São Domingos, 22.I.2015, fr., 14²7'21,5”S, 4231'6"W, R.L. Borges et al. 262 (ALCB, HUEFS).

Material adicional examinado: Licínio de Almeida, 2 $\mathrm{km}$ antes da entrada da cidade, 10.I.2006, 14 $4^{\circ} 53^{\prime} 44,4$ 'S, 42 53'8,3'W, fl. e fr., T.S. Nunes et al. 1637 (HUEFS).

Coutarea hexandra é uma espécie amplamente distribuída, ocorrendo em diversas formações vegetais e fitofisionomias (BFG 2015), tendo sido relatada em diversos trabalhos ao longo da cadeia do espinhaço (Campos et al. 2006; Sousa et al. 2013; Zappi et al. 2014). Caracteriza-se por apresentar ramos lenticelados, flores alvas localmente, anteras lineares amarelas e frutos capsulares com semente alada. Na SGLA, C. hexandra ocorre em florestas estacionais e áreas antropizadas.
8. Declieuxia Kunth, Nov. Gen. Sp. 3: 352. 1818. Ervas, arbustos ou subarbustos. Ramos eretos, ramificados, cilíndricos ou angulares. Folhas opostas ou verticiladas, sésseis a pecioladas; estípula inteira, linear, ou reduzida à linha estipular, glandular; lâmina foliar elíptica, linear, lanceolada ou ovada. Inflorescências em dicásios, tirsos ou flores solitárias, terminais ou axilares, sésseis a pedunculadas. Flores pediceladas a sésseis; cálice 4-lobado; corola 4-lobada, hipocrateriforme; anteras oblongas; ovário bilocular, um óvulo por lóculo, estigma bífido. Fruto esquizocárpico, 2 mericarpos, lenticular. Semente compressa-aplainada.

Declieuxia é um gênero neotropical com ca. 29 espécies (Govaerts et al. 2016), das quais 28 ocorrem no Brasil, distribuídas principalmente ao longo da Cadeia do Espinhaço e Brasil central (Kirkbride 1976; BFG 2015). Na SGLA, Declieuxia está representada por cinco espécies, caracterizando-se por apresentar hábito arbustivo ou subarbustivo, flores alvas, azuis ou lilás e frutos esquizocárpicos, lenticulares.

\section{Chave de identificação das espécies de Declieuxia}

1. Folhas eretas, adpressas ao caule, lâmina lanceolada, internós não visíveis, estípula inconspícua, reduzida a linha estipular Declieuxia passerina

1’. Folhas patentes, não adpressas, lâmina linear ou elíptica, internós visíveis, estípula linear, 1-lobada ..

2. Folhas verticiladas, dispostas em braquiblastos, lâmina foliar linear.....Declieuxia aspalathoides

2'. Folhas opostas, não dispostas em braquiblastos, lâmina foliar elíptica. Declieuxia fruticosa

3. Superfície foliar bulada

3'. Superfície foliar lisa 4

4. Lâmina foliar 4,4-8,4 cm compr., mericarpos papilosos .............. Declieuxia tenuiflora

4'. Lâmina foliar 0,6 cm compr., mericarpos estrigosos Declieuxia cacuminis

8.1. Declieuxia aspalathoides Mull. Arg., Fl. bras. 59: 437.1876.

Fig. 4h,i

Arbustos $20-50 \mathrm{~cm}$ alt. Ramos cilíndricos, estriados, estrigosos. Folhas verticiladas, sésseis, dispostas em braquiblastos, opostos; estípula linear, estreitamente triangular a linear, estrigosa, 0,6-1 $\times$ ca. $0,2 \mathrm{~mm}$; lâmina linear, revoluta, ápice agudo, base truncada, ca. $0,3 \times 0,06 \mathrm{~cm}$, lisa, cartácea, discolor, glabra na face adaxial, estrigosa na face abaxial. Tirso terminal, subséssil (pedúnculo ca. $0,2 \mathrm{~mm}$ compr.); brácteas lanceoladas, 2,4-3,7 × ca. 0,5 mm., estrigosas. Flores sesseis; lobos do cálice linearlanceolados, $0,1-0,3 \times$ ca. $0,05 \mathrm{~mm}$, verdes, glabros; corola ca. 4,5 mm compr., tubo $2,3-3 \mathrm{~mm}$ compr., alvo glabro externamente, tomentoso internamente, lobos da corola triangulares, ápice agudo, alvos a lilás, glabros externamente, papilosos internamente; anteras ca. 0,9 $90,3 \mathrm{~mm}$, lilás, glabras; estilete ca. $2,5 \mathrm{~mm}$ compr., alvo, glabro; lobos do estigma ca. $0,5 \mathrm{~mm}$ compr., papilosos. Fruto 1,2-2 ×2,2-3 mm, verde-enegrecido quando maduro, glabro. Semente $0,8-1 \times 0,7-0,9 \mathrm{~mm}$, creme, superfície lisa.

Material examinado: Licínio de Almeida, Lameirão, 22.II.2014, fl., 1441'37,7'S, 42³2'7,5”W, N. Roque et al. 4185 (ALCB, HUEFS); Cascarrento, 22.I.2013, fl. e fr., 14'33'13,9'S, 42³3'28,2'W, R.L. Borges et al. 82 (ALCB); Trilha para o cachoeirão, 14.V.2015, fl. e fr., 1441'25,6”S, 42³2'34,3'W, R.L. Borges et al. 295 (ALCB, CEPEC, HUEFS). 

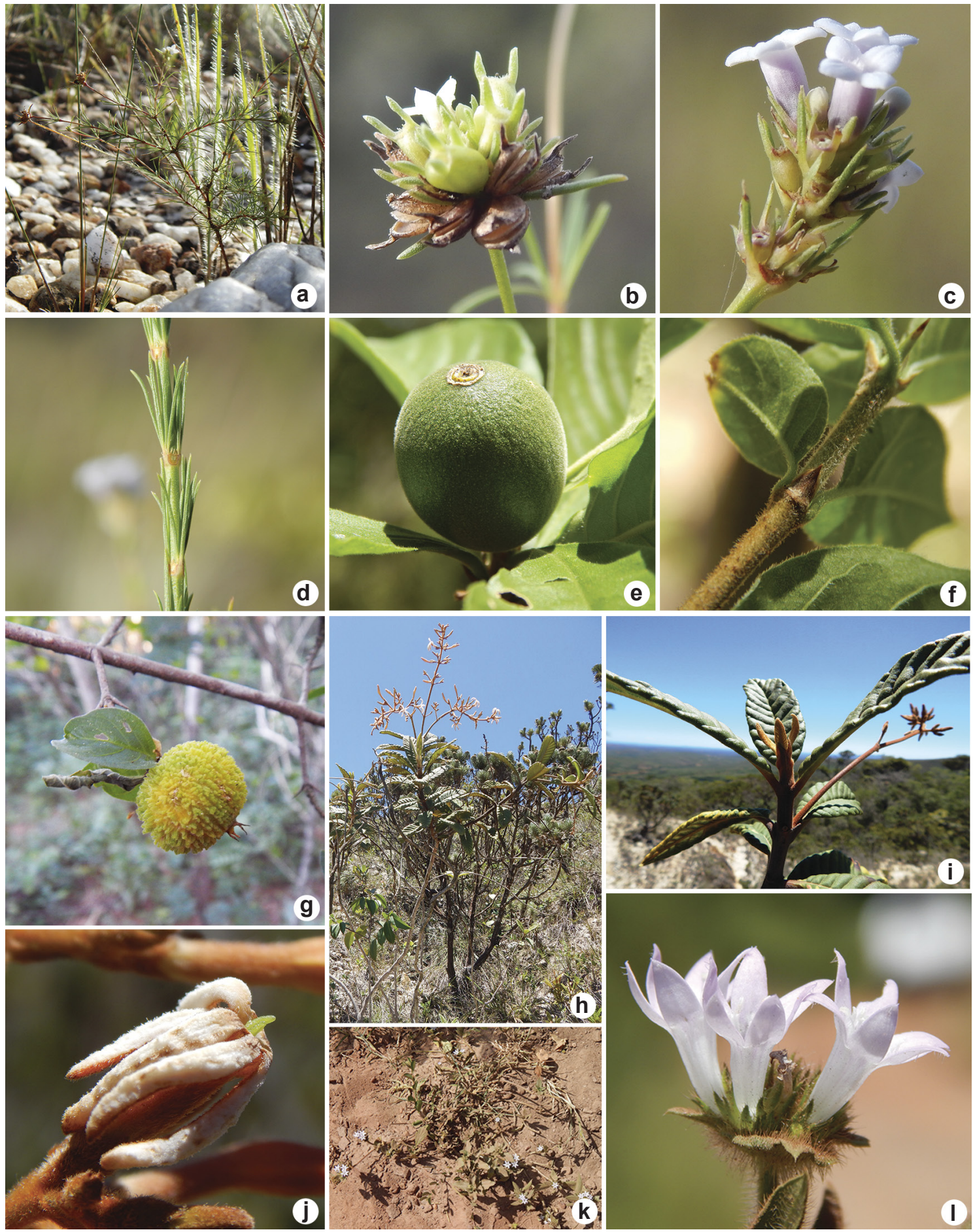

Figura 9 - a,b. Psyllocarpus asparagoides - a. hábito; b.inflorescência. c,d. Psyllocarpus laricoides - c. inflorescência; d. folhas. e,f. Randia calycina - e. fruto; f. estípula. g. Randia sp. - fruto muricado. h-j. Remijia ferruginea - h. hábito; i. ápice caulinar, evidenciando filotaxia trística; j. flor. k,1. Richardia grandiflora - k. hábito; 1. inflorescência. Figure 9 - a,b. Psyllocarpus asparagoides - a. habit; b. inflorescence. c,d. Psyllocarpus laricoides - c. inflorescence; d. leaves. e,f. Randia calycina - e. fruit; f. stipule. g. Randia sp. - muricate fruit. h-j. Remijia ferruginea - h. habit; i. stem apex, showing tristic phyllotaxy; j. flower. k,1. Richardia grandiflora - k. habit; 1. inflorescence. 
Declieuxia aspalathoides é uma espécie com ampla distribuição em áreas de Cerrado na Bahia, Minas Gerais, Sergipe e Centro Oeste (Kirkbride 1976). Na SGLA, a espécie está associada a áreas de cerrado sensu stricto e campos rupestres. $D$. aspalathoides diferencia-se das demais Decliexia na SGLA por apresentar folhas lineares ( $v s$. folhas lanceoladas e elípticas), verticiladas, condensadas em braquiblastos, opostos ( $v s$. duas folhas por nó).

8.2. Declieuxia cacuminis Mull.Arg., Fl. bras. 59(28): 438. 1876

Arbustos ca. $25 \mathrm{~cm}$ alt. Ramos cilíndricos, estriados, estrigosos. Folhas opostas, subsésseis (pecíolo 0,5-0,9 mm compr.); estípula linear, $0,5-0,7 \times$ ca. $0,1 \mathrm{~mm}$, estrigosa; lâmina elíptica, ápice agudo, base atenuada, ca. $6 \times 2 \mathrm{~mm}$, lisa, cartácea, discolor, estrigosa em ambas as faces. Dicásio axilar, modificado em cimeira escorpioide, pedunculado (pedúnculo 1,5-4 $\mathrm{mm}$ compr.); brácteas triangulares ca. $1 \times 0,2 \mathrm{~mm}$, estrigosas. Flores sésseis; lobos do cálice triangulares, ca. $0,3 \times 0,1 \mathrm{~mm}$, verdes, estrigosos; corola ca. $3 \mathrm{~mm}$ compr., tubo ca. 1,8 mm compr., lilás, estrigoso externamente, tomentoso internamente, lobos da corola triangulares, ápice agudo, lilás, estrigosos externamente, tomentosos internamente; anteras ca. $0,7 \times 0,3 \mathrm{~mm}$, lilás, glabras; estilete ca. 0,8 $\mathrm{mm}$ compr., verde, glabro, lobos do estigma ca. 0,3 $\mathrm{mm}$ compr., papilosos. Fruto $1,1 \times 1,8 \mathrm{~mm}$, verdeenegrecido quando maduro, estrigoso. Semente 0,7-1,5 × 0,5-1,2 mm, creme, superfície lisa. Material examinado: Licínio de Almeida, Campo rupestre do Xaxá, 20.I.2015, 1439'11'’S, 42³3'3,4”W, R.L. Borges et al. 235 (ALCB, CEPEC, HUEFS); Trilha para Cachoeira das Sete Quedas, 22.V.2013, 14³1'1,5”'S, 42³2'W, R.L. Borges et al. 131 (ALCB, CEPEC); Trilha para Riacho fundo, 5.XI.2013, 14³7'42,2”S, 42³0'39,9’W, R.L. Borges et al. 175 (ALCB, HUEFS).

Material adicional examinado: Licínio de Almeida (ca. 12 km em direção a Brejinho das Ametistas), 12.III.1994, 14'32'4'S, 42³1'51'W, N. Roque et al. (SPF)

Declieuxia cacuminis é uma espécie endêmica dos campos rupestres na Cadeia do Espinhaço (Minas Gerais e Bahia) e planalto central do Brasil (BFG 2015). De acordo com Kirkbride (1976), existem duas variedades de D. cacuminis (var. cacuminis e var. decurrens). Na SGLA ocorre apenas à variedade decurrens, restrita a Cadeia do Espinhaço, caracterizando-se por apresentar folhas elípticas diminutas e ramos com internós evidentes, com aspecto não ericoide. Entre as espécies da SGLA, D.cacuminis var. decurrens diferencia-se por apresentar folhas subsésseis ( $v s$. folhas pecioladas e sésseis) e lâmina ca. 0,6 cm compr. (vs. $0,3 \mathrm{~cm}$ em D. aspalathoides e 1,3-8,4 cm compr. nas demais espécies).

8.3. Declieuxia fruticosa (Willd. ex Roem. \& Schult.) O.Kuntze, Revis. gen. pl.1: 279. 1891.

Fig. $4 \mathrm{j}, \mathrm{k}$

Arbustos ca. $30 \mathrm{~cm}$ alt. Ramos cilíndricos, lisos, denso-estrigosos. Folhas opostas, pecioladas (pecíolo ca. $2 \mathrm{~mm}$ compr.); estípula linear, 2,1-3,9 $\times$ ca. $0,5 \mathrm{~mm}$, decorrente, estrigosa; lâmina ovada, revoluta, ápice agudo, base atenuada, ca. $2 \times 0,4-1,2 \mathrm{~cm}$, bulada, cartácea, discolor, estrigosa em ambas as faces. Tirso terminal, subséssil (pedúnculo ca. 0,5 $\mathrm{mm}$ compr.); brácteas lanceoladas, ca. 4,7 $\times 0,8 \mathrm{~mm}$, estrigosas externamente, glabras internamente. Flores sesseis; lobos do cálice triangulares, ca. 0,5 × 0,2 $\mathrm{mm}$, verdes, estrigosos; corola ca. $5 \mathrm{~mm}$ compr., tubo ca. 2,8 mm compr., rosa a lilás, estrigoso externamente, tomentoso internamente, lobos triangulares, ápice agudo, róseos a lilás, papilosos internamente, estrigosos externamente; anteras ca. $0,9 \times 0,4 \mathrm{~mm}$, alvas, glabras; estilete ca. 4 $\mathrm{mm}$ compr., alvo, glabro, lobos do estigma ca. $0,5 \mathrm{~mm}$ compr., papilosos. Fruto ca. 2,6 $64 \mathrm{~mm}$, enegrecido quando maduro, estrigoso. Semente ca. $1,7 \times 1,3 \mathrm{~mm}$, creme, superfície lisa.

Material examinado: Licínio de Almeida, Fazenda Riacho de areia, 24.V.2013, fl. e fr., 14 $45^{\prime} 28^{\prime \prime}$, $42^{\circ} 34^{\prime} 37,5^{\prime}$ 'W, R.L. Borges et al. 156 (HUEFS, ALCB, CEPEC).

Declieuxia fruticosa é uma espécie amplamente distribuída ao longo do país, ocorrendo em todos os estados e em diversos domínios fitogeográficos (BFG 2015; Kirkbride 1976). A espécie apresenta ampla variação morfológica e na SGLA foi encontrado apenas o morfotipo descrito por Kirkibride (1976) como típico de áreas associadas a campos rupestres no sudoeste da Bahia. Esta espécie diferencia-se das demais espécies que ocorrem na SGLA, por apresentar lâmina foliar bulada ( $v s$. superfície foliar lisa) e ramos com indumento estrigoso denso.

8.4. Declieuxia passerina Mart. ex. Zucc., Mant.3: $112,1827$.

Figs. 41; 11a-d

Subarbusto até $30 \mathrm{~cm}$ alt. Ramos cilíndricos, lisos, estrigosos a glabrecentes. Folhas opostas, eretas, adpressas ao caule, sésseis; estípula inconspícua, reduzida a linha estipular, estrigosa; lâmina lanceolada, ápice acuminado, base cuneada, 

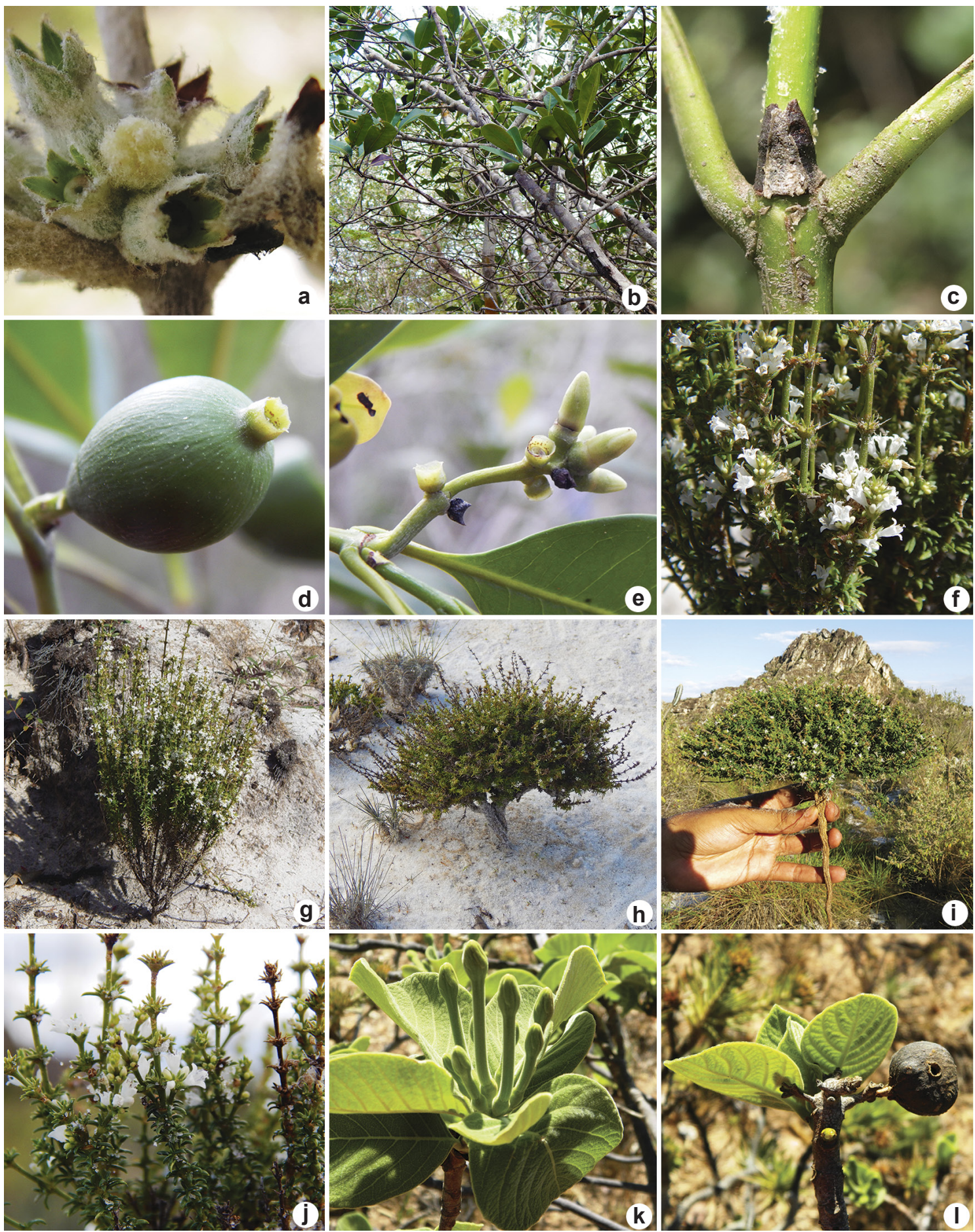

Figura 10 - a. Sabicea brasiliensis - glomérulo; b-e. Stachyarrhena reflexa - b. habito; c. estípula; d. fruto; e. inflorescência. f,g. Staelia virgata -f. inflorescência; g. hábito. h-j. Staelia sp. - h. hábito; i. hábito; j. inflorescência. k,1. Tocoyena formosa $-\mathrm{k}$. inflorescência; 1 . fruto.

Figure 10 - a. Sabicea brasiliensis - glomerule; b-e. Stachyarrhena reflexa - b. habit; c. stipule; d. fruit; e. inflorescence. f,g. Staelia virgata $-\mathrm{f}$. inflorescence; g. habit. h-j. Staelia sp. - h. habit; i. habit, showing plant length; j. inflorescence. k,l. Tocoyena formosa $-\mathrm{k}$. inflorescence; 1. fruit. 
$1,2-1,3 \times 0,4-0,8 \mathrm{~cm}$, lisa, cartácea, discolor, glabra. Dicásio axilar, pedunculado (pedúnculo ca. 3,5 mm compr.); brácteas lanceoladas, ca. 7 $\times 0,6 \mathrm{~mm}$, glabras. Flores sesseis; lobos do cálice lanceolados ca. $0,6 \times 0,1 \mathrm{~mm}$, verdes, glabros; corola ca. $6,1 \mathrm{~mm}$ compr., lilás, tubo 3,1-3,6 mm compr., lilás, glabro externamente, tomentoso internamente, lobos ovados, ápice agudo, glabros externamente, papilosos internamente; anteras ca. $0,9 \times 0,3 \mathrm{~mm}$, magentas, glabras; estilete 4,8-5,5 mm compr., alvo, glabro, lobos do estigma ca. $0,9 \mathrm{~mm}$ compr., papilosos. Fruto $1,3-2,6 \times 2-4,2 \mathrm{~mm}$, verde-enegrecido quando maduro, liso, glabro. Semente ca. 1,6 $\times 1,3 \mathrm{~mm}$, castanha, superfície lisa.

Material examinado: Licínio de Almeida, Fazenda riacho de areia, 21.I.2013, fl., 1445' 7,6's, 42 $2^{\circ} 32^{\prime} 41,4^{\prime \prime} \mathrm{W}$, R.L. Borges et al. 76 (ALCB, CEPEC); Saco da onça,

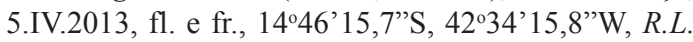
Borges et al. 112 (ALCB); Fazenda Riacho de areia, 24.V.2013, fl. e fr., $14^{\circ} 45^{\prime} 28^{\prime \prime}$ 'S, $42^{\circ} 34^{\prime} 37,5^{\prime \prime} \mathrm{W}$, R.L. Borges et al. 155 (ALCB, CEPEC, HUEFS).

Material adicional examinado: Montugaba, ca. $8 \mathrm{~km}$ em direção a Jacarau, 16.III.1994, fl. e fr., 1453'7'S, 42'28’3”W, V.C. Souza et al. 5536 (SPF); BRASIL. MINAS GERAIS: Monte Azul, ca. 14,7 km SE de Monte

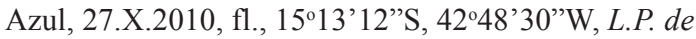
Queiroz et al. 14927 (HUEFS).

Declieuxia passerina é uma nova ocorrência para o estado da Bahia, uma vez que era citada apenas para Minas Gerais (BFG 2015; Kirkbride 1976), ocorrendo na Serra do Cipó (Zappi et al. 2014). A espécie ocorre predominantemente em áreas de campo rupestre e na SGLA, ocorre em áreas que apresentam tal fitofisionomia. $D$. passerina diferencia-se das demais espécies de Declieuxia na SGLA pelas folhas eretas, adpressas ao caule ( $v s$. folhas patentes) e lâmina foliar lanceolada (vs. elíptica, ovada e linear).

8.5. Declieuxia tenuiflora (Willd. ex Roem. \& Schult) Steyrm. \& J.H. Kirkbr. Mem. New York Bot. Gard. 23: 399. 1972.

Arbusto $30-50 \mathrm{~cm}$ alt. Ramos cilindricos, estriados, glabros. Folhas pecioladas (pecíolo $3,2-6,6 \mathrm{~mm}$ ); estípula linear, $2,1-3 \times$ ca. 0,4 $\mathrm{mm}$, decorrente, estrigosa; lâmina elíptica, ápice agudo, base atenuada, 4,4-8,4 × 1,6-2,6 cm, lisa, membranácea, discolor, estrigosa ao longo das margens e nervuras. Dicásios modificados em cimeiras escorpioides, axilares e terminais; brácteas lanceoladas $1,2-2,2 \times$ ca. $0,4 \mathrm{~mm}$, estrigulosas. Flores subsésseis (pedicelo ca. 0,4 $\mathrm{mm}$ compr.); lobos do cálice, triangulares, ca.
$0,4 \times 0,2 \mathrm{~mm}$, verdes, glabros; corola 3-3,5 mm compr., tubo 1,6-2,2 $\mathrm{mm}$ compr., azul, glabro externamente, tomentoso internamente, lobos ovados, azuis, glabros externamente, tomentosos internamente; anteras ca. $0,8 \times 0,4 \mathrm{~mm}$, alvas, glabras; estilete $2,6-4,1 \mathrm{~mm}$ compr., alvo, glabro, lobos do estigma ca. $0,5 \mathrm{~mm}$ compr., papilosos. Fruto 1,6-1,7 × 2,8-3,1 mm, castanho, papiloso. Semente ca. 1,6 $\times 1,1 \mathrm{~mm}$, creme, superfície lisa. Material examinado: Licínio de Almeida, Trilha Xaxá-Cachoeirão, 21.I.2013, fl. e fr., 1441'18,7'S, 42'33'2,6”'W, R.L. Borges et al. 90 (ALCB, HUEFS, CEPEC); São Domingos de Baixo, 22.I.2015, fl. e fr., 14'27'21,5"S, 42³1'6”'W, R.L. Borges et al. 256 (ALCB e HUEFS); Trilha para o Cachoeirão, 13.V.2015, fl.

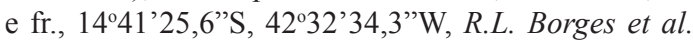
293 (ALCB).

Declieuxia tenuiflora é uma espécie de ampla distribuição, ocorrendo em todos os domínios fitogeográficos do Brasil (BFG 2015; Kirkbride 1976). Na SGLA esta espécie está principalmente associada ao subosque de floresta estacional, diferenciando-se das demais, comumente encontradas em áreas abertas de campos rupestres e cerrado sensu stricto. D. tenuiflora diferencia-se das demais espécies por apresentar folhas membranáceas (vs. cartácea), e frutos com indumento papiloso ( $v s$. estrigoso ou glabro).

9. Emmeorhiza umbellata K.Schum., Fl. bras. 6(6): 408. $1889 . \quad$ Fig. 5h,i

Trepadeira. Ramos volúveis, angulares, estriados, estrigosos. Folhas opostas, pecioladas (pecíolo $2 \mathrm{~mm}$ compr.); estípula 6-fimbriada, estrigosa, bainha 2,1-2,6 mm compr., fímbrias linear-triangulares, ca. $3 \times 0,3 \mathrm{~mm}$; lâmina elíptica, ápice acuminado, base decorrente, 3,2-4,1 $\times$ ca. $1 \mathrm{~cm}$, lisa, membranácea, discolor, estrigosa adaxialmente, glabra abaxialmente. Inflorescência umbeliforme, terminal, pedunculada (pedúnculo 1,3-1,4 cm compr.); brácteas estreitamente elípticas, foliáceas, ca. $6,1 \times 2,4 \mathrm{~mm}$, verdes, estrigosas adaxialmente, glabras abaxialmente. Flores pediceladas (pedicelo 3-4,4 mm compr.); cálice 4-lobado, lobos estreitamente triangulares, $2 \times$ ca. $0,3 \mathrm{~mm}$, verdes, glabros; corola 4-lobada, sub-rotácea, 1,6 mm compr., alva, tubo ca. $0,5 \mathrm{~mm}$ compr., glabro externamente, piloso internamente, lobos triangulares, ápice agudo, ca. 1,1 ×0,6 mm, estrigosos externamente, glabros internamente; anteras elípticas, ca. 0,7 $\times 0,3 \mathrm{~mm}$, extrorsas. alvas, glabras; estilete ca. 1,5 mm compr., alvo, 

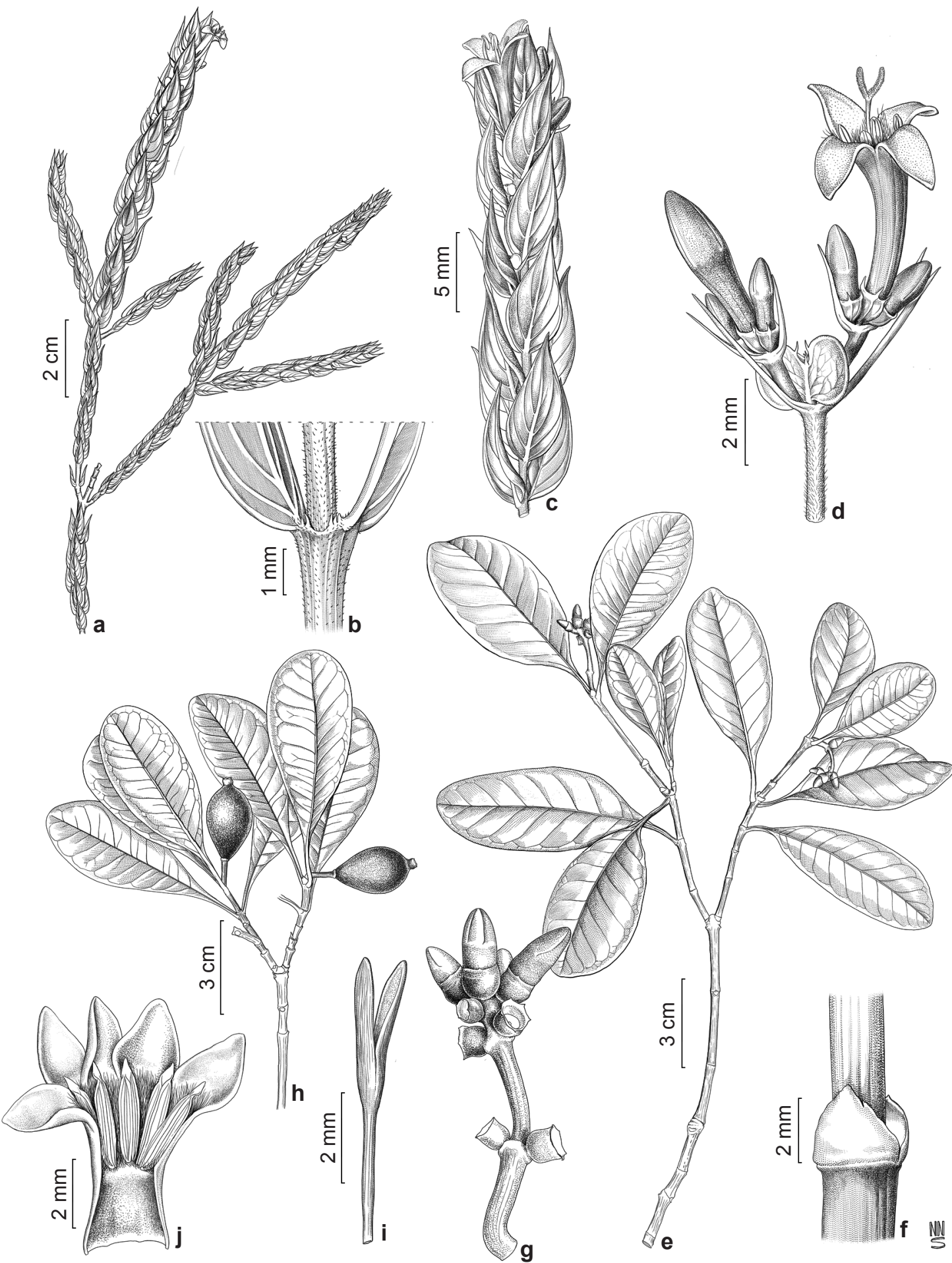

Figura 11 - a-d. Declieuxia passerina - a. hábito; b. estípula; c. ramo com folhas eretas; d. inflorescência. e-j. Stachyarrhena reflexa - e. inflorescência masculina; f. estípula; g. inflorescência espiciforme; h. ramo com frutos bacáceos; i. estilete e estígma; j. secção longitudinal da corola de uma flor masculina mostrando os estames epipétalos. Figure 11 - a-d. Declieuxia passerina - a. habit; b. stipule; c. branch with erect leaves; d. inflorescence. e-j. Stachyarrhena reflexa - e. male inflorescence; f. stipule; g. spiciform inflorescence; $h$. branch with berry fruits; i. style and stigma; j. longitudinal section of a male flower showing epipetalous stamen. 
glabro, estigma bífido, lobos do estigma ca. 0,5 mm compr., papilosos. Fruto cápsula, septicida, 2,4 $\mathrm{mm}$ compr., verde a ferrugíneo quando passados, puberulento. Semente alada, 2,5 × 0,8 $\mathrm{mm}$, ferrugínea, lisa.

Material examinado: Licínio de Almeida, Mata estacional do Xaxá, 12.V.2015, 14³8'45,7"S, 4233'16,8”W, fl., R.L. Borges et al. 276 (HUEFS, ALCB).

Material adicional examinado: Piatã, Caminho para a Cachoeira do Cochó, 12.V.2015, 1386,1"S, $41^{\circ} 88^{\prime} 05,5$ "W, fl. e fr., M.L. Guedes et al. 21773 (ALCB).

Emmeorhiza é um gênero monotípico, neotropical, representado pela espécie $E$. umbellata. No Brasil, Emmeorhiza é amplamente distribuída, ocorrendo em diversas formações fitofisionômicas (BFG 2015). E. umbellata caracteriza-se por apresentar hábito trepador, inflorescência umbeliforme, flores sub-rotundas, aromáticas e sementes aladas. Na SGLA, E. umbellata está associada a florestas estacionais.

10. Faramea Aubl., Hist. P1. Guiane 1: 102. 1775. Arbustos ou árvores. Ramos cilíndricos ou compressos no ápice, eretos. Folhas opostas, sésseis, subsésseis ou pecioladas; estípula inteira, ápice aristado; lâmina foliar elíptica a lanceolada. Inflorescência em dicásio ou tirso, axilar ou terminal. Flores pediceladas ou sésseis; cálice 4-lobado, lobos fusionados; corola 4-lobada, infundibuliforme; antera elíptica a lanceolada; ovário 2-locular, um óvulo por lóculo, estigma bífido. Fruto drupáceo, oblado, globoso ou reniforme. Semente oblada, base escavada ventralmente.

Faramea é um gênero neotropical, compreendendo ca. 200 espécies, distribuídas do México a Argentina (Govaerts et al. 2016). No Brasil são encontradas 52 espécies, associadas a diversos domínios fitogeográficos e formações vegetais (BFG 2015). Faramea caracteriza-se por apresentar estípula triangular com ápice aristado; fruto drupáceo globoso a reniforme e semente escavada ventralmente (Jardim 2008).

10.1. Faramea nigrescens Mart., Flora 24(2): 73. 1841 .

Fig. 6d

Árvore até $5 \mathrm{~m}$ alt. Ramos cilíndricos, estriados, glabros. Folhas pecioladas (pecíolo 2,9-7,2 mm compr.); estípula triangular, ápice aristado, glabra; lâmina elíptica, ápice acuminado, base atenuada, 7-8,4 × 3,1-4,4 cm, lisa, coriácea, discolor, glabra. Tirso terminal, pedunculado (pedúnculo 2,4-2,7 cm compr.); brácteas triangulares, $0,8 \times 0,4 \mathrm{~mm}$, vináceas, glabras. Flores pediceladas (pedicelo 1,8-4,3 mm compr.); cálice tubular ca. 1,7 mm compr., verde-vináceo, glabro; corola 1,2 cm compr., tubo ca. $1 \mathrm{~cm}$ compr., lilás, glabro, lobos triangulares, ápice agudo, lilás, glabros; anteras ca. 3,5 $\times 1 \mathrm{~mm}$, alvas, glabras; estilete ca. 6 $\mathrm{mm}$ compr., alvo, glabro, lobos do estigma ca. $3 \mathrm{~mm}$ compr., papilosos. Fruto oblado, 5,1-6,8 $\times$ 7,4-8,7 mm, atropurpúreo quando maduro, glabro. Semente 4,7-5,1 × ca. $7 \mathrm{~mm}$, castanha, escavada ventralmente.

Material examinado: Licínio de Almeida, Floresta estacional do Xaxá, 12.V.2015, 1445'8"S, 4232'41'W, R.L. Borges et al. 279 (ALCB, HUEFS). Material adicional examinado: Caetité, Estrada para Brejinhos das Ametistas, 13.IV.1980, fr., 13'99'30"S, 42²0'75"W, R.M. Harley et al. 21340 (ALCB); Estrada para Licínio de Almeida, 10.II.1997, fr., 14'16'S, 4249'61'W, E. Saar et al. 5373; Piatã, Fazenda Beija-Flor, 13.X.2006, fl., 1315'S, 4176'66”W, M.L. Guedes et al. 12549 (ALCB).

Faramea nigrescens é uma espécie distribuída nos estados da Bahia, Goiás, Minas Gerais e Tocantins em áreas de Cerrado (BFG 2015), tendo ampla representatividade ao longo da Cadeia do Espinhaço (Zappi et al. 2014; Campos et al. 2006). F. nigrescens caracteriza-se por apresentar ramos glabros e flores com corola alvo-lilás e na SGLA, ocorre associada a áreas de floresta estacional.

11. Galianthe Griseb., Abh. Konigl. Ges. Wiss. Gottingen 24: 156. 1879.

Ervas, arbustos ou subarbustos. Ramos cilíndricos ou angulares, prostrados, escandentes ou eretos. Folhas sésseis ou subsésseis; estípula 1-multifimbriada; lâmina elíptica ou linear. Inflorescência em tirso ou pleiotirso, terminal. Flores sésseis ou subsésseis; cálice 2-4 lobado; corola 4-lobada, infundibuliforme; antera elíptica, excertas; ovário 2-locular, um óvulo por lóculo, estilete glabro, estigma bífido. Fruto cápsula, 2-mericarpos, septicida. Semente oblonga, reticulado-foveolada.

Galianthe é um gênero neotropical apresentando ca. 49 espécies (Cabral 2009). No Brasil o gênero está representado por 36 espécies, associadas a diversas fitofisionomias (BFG 2015). Galianthe caracteriza-se por apresentar inflorescência em tirso, terminal; flores diminutas e frutos capsulares com deiscência longitudinal (Cabral 2009). 
11.1. Galianthe peruviana (Pers.) Cabral, Bonplandia 6(4): 26. $1993 . \quad$ Fig. 6e-g

Subarbusto entre $30-40 \mathrm{~cm}$ alt. Ramos cilíndricos, eretos, estriados, esfoliantes, puberulentos a glabrescentes. Folhas sésseis; estipula 5-fimbriada, puberulenta, bainha ca. 1,1 mm compr., fimbrias linear triangulares, ca. 3,4 × 0,3 mm; lâmina linear, revoluta, ápice agudo, base truncada, ca. 1,5 × 0,1 cm, lisa, cartácea, concolor, puberulenta. Tirso terminal, pedunculado (pedúnculo ca. $5 \mathrm{~mm}$ compr.); brácteas linear-triangulares, 3,2-3,5 $\times$ ca. $0,5 \mathrm{~mm}$, verdes, glabras. Flores sésseis; cálice 4-lobado, lobos do cálice triangulares, ca. $1 \times 0,5 \mathrm{~mm}$, verdes, glabros; corola ca. 2,5 $\mathrm{mm}$ compr., tubo ca. $1 \mathrm{~mm}$ compr., alvo, glabro externamente, tomentoso internamente, lobos triangulares, alvos, papilosos externamente, tomentosos internamente; anteras ca. $0,8 \times 0,3$ $\mathrm{mm}$, alvas, glabras; estilete ca. 1,2 mm compr., alvo, glabro, lobos do estigma ca. 0,3 $\mathrm{mm}$ compr., papilosos. Fruto $2,7 \times 2 \mathrm{~mm}$, verde a castanho, puberulento. Semente ca. $2,5 \times 1,1 \mathrm{~mm}$, castanha, superfície reticulada.

Material examinado: Licínio de Almeida, Saco da Onça, 27.V.2014, fl. e fr., 1444'38,9'S, 42³4'22,5”'W, R.L. Borges et al. 184 (ALCB, CEPEC, HUEFS); Saco da Onça, 14.V.2015, fl. e fr., 1444'38,9'S, 4234'22,5”W, R.L. Borges et al. 298 (ALCB, CEPEC, HUEFS).

Galianthe peruviana é uma espécie que ocorre na Bolívia, Brasil e Peru, estando associada a áreas de elevada altitude (Cabral
2009). No Brasil, G. peruviana, ocorre em áreas de campos rupestres, presente nos estados do Mato Grosso, Mato Grosso do Sul, São Paulo e Minas Gerais (Cabral 2009; BFG 2015), sendo, portanto, uma nova ocorrência para o estado da Bahia. Na SGLA, G. peruviana está associada a áreas de Cerrado sensu stricto, caracterizando-se por apresentar hábito subarbustivo com aspecto ericoide, folhas lineares e flores diminutas, alvas.

12. Guettarda L., Sp. P1. 2: 991. 1753.

Árvores. Ramos eretos, cilíndricos. Folhas opostas, pecioladas; estípula inteira; lâmina foliar elíptica ou ovada. Inflorescência em dicásios axilares ou terminais, ramos laterais modificados em cimeiras escorpioides. Flores pediceladas, subsésseis ou sésseis; cálice 5-lobado, lobos fusionados, cilíndrico; corola 5-6 lobada, hipocrateriforme; anteras oblongas ou lineares; ovário bilocular, um óvulo por lóculo, estigma capitado. Fruto carnoso, drupáceo, globoso ou elipsoide, roxo, branco a creme quando maduro. Semente elipsoide ou oblada.

Guettarda é um gênero Neotropical com ca. 150 espécies (Achille et al. 2006). No Brasil, são registradas, 20 espécies distribuídas em todas as regiões do país e em diversos domínios fitogeográficos (BFG 2015). Na SGLA, Guettarda está representada por duas espécies, caracterizando-se por apresentar fruto drupa e inflorescências axilares em dicásios, com ramos laterais modificados em cimeiras escorpioides.

\section{Chave de identificação das espécies de Guettarda}

1. Lâmina foliar elíptica; drupa elipsoide, roxa quando madura, semente elipsoide.... Guettarda sericea

1'. Lâmina foliar ovada a largamente ovada; drupa globosa, branca a creme quando madura Guettarda viburnoides

12.1. Guettarda sericea Mull.Arg. Fl. bras. 58: 450. 1875. Figs. 6h; 8d,e

Árvores até $4 \mathrm{~m}$ alt. Ramos cilíndricos, estriados, seríceos a glabrescentes. Pecíolo 1,6-6,3 cm compr.; estípula triangular, $0,8-1$ $\times 0,4-0,6 \mathrm{~cm}$, serícea; lâmina elíptica, ápice agudo, base cuneada, $6,7-13,3 \times 3,9-11,2$ $\mathrm{cm}$, lisa, cartácea, discolor, serícea. Dicásios pedunculados (pedúnculo 1,7-2,5 cm compr.), axilares, tomentosos; brácteas lanceoladas, ca. 6 $\times 1 \mathrm{~mm}$., ferrugíneas, tomentosas. Flores sésseis; cálice $2-2,3 \mathrm{~mm}$ compr., verde, tomentoso externamente, glabro internamente; corola $1-1,4$ cm compr., tubo 0,8-1,2 cm compr., creme, seríceo externamente, glabro internamente, lobos ovados, ápice arredondado, cremes, sericeos externamente, glabros internamente; anteras oblanceoladas, 3-3,2 $\times 0,6-0,7 \mathrm{~mm}$, cremes, glabras; estilete $5,8-6,7 \mathrm{~mm}$ compr., creme, glabro, estigma ca. $0,5 \mathrm{~mm}$ compr., papiloso. Fruto elipsoide, ca. $8,8 \times 4,7 \mathrm{~mm}$, verde a roxo, tomentoso. Semente elipsoide, ca. $8,7 \times 4,4$ $\mathrm{mm}$, castanho-amarronzada.

Material examinado: Licínio de Almeida, Estrada

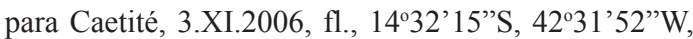


A. Rapini et al. 1325 (HUEFS); São Domingos de baixo, 22.I.2015, fr., 14²7'21,55"S, 42³1' 6"W, R.L. Borges et al. 259 (ALCB, CEPEC, HUEFS).

Guettarda sericea é uma espécie endêmica do Nordeste brasileiro, ocorrendo no domínio da Caatinga (BFG 2015). Na SGLA, foi encontrada em área de floresta estacional. A espécie diferencia-se de G. viburnoides por apresentar fruto elipsoide ( $v s$. globoso), roxo ( $v s$. creme a amarelo) quando maduro e lâmina elíptica ( $v s$. lâmina ovada a largamente ovada).

12.2. Guettarda viburnoides Cham. \& Schltdl., Linnaea 4: 182. 1829.

Figs. 6i-1; 8f,g

Arbustos 1-4,5 m alt. Ramos cilíndricos, estriados, tomentosos a glabrescentes. Pecíolo 1,2-3 cm compr.; estípula triangular, 8,7-10,7 × 4,1-7,1 cm, tomentosa; lâmina ovada a largamente ovada, ápice agudo, base arredondada, 9,6-13 × 7,2-11 cm, lisa, cartácea, discolor, tomentosa. Dicásios pedunculados (pedúnculo 1,7-2,5 cm), axilares, tomentosos; brácteas lanceoladas, ca. $6 \times 1 \mathrm{~mm}$., ferrugíneas, tomentosas. Flores subsésseis (pedicelo ca. 0,3 mm compr.); lobos do cálice ca. $4 \mathrm{~mm}$ compr., verdes, tomentosos externamente; corola 3,5-3,6 cm compr., tubo ca. 2,9-3,2 cm compr., creme, tomentoso; lobos ovados, ápice arredondado, tomentosos externamente, glabros internamente; anteras oblongas, ca. $4 \times 0,5-0,7$ $\mathrm{mm}$, cremes, glabras; estilete ca. $3 \mathrm{~mm}$ compr., creme, piloso, estigma, ca. 1,5 mm compr., tomentoso. Fruto globoso, 7-7,1 × 8,8-10 mm, verde a creme, tomentoso. Semente oblada, ca. $5,5 \times 7,9 \mathrm{~mm}$, castanha, glabra.
Material examinado: Licínio de Almeida, Subida para Riacho de Areia, 20.I.2015, fl., 1445'32,5"S, 42'34'38,3"W, R.L. Borges et al. 211 (ALCB, CEPEC, HUEFS); Mata do Riacho de Areia, 21.I.2015, fl., 14 ${ }^{\circ} 46^{\prime} 54,7^{\prime}$ 'S, 42 $34^{\prime} 4,9^{\prime}$ 'W, R.L. Borges et al. 224 (ALCB, HUEFS).

Guettarda viburnoides é uma espécie amplamente distribuída, ocorrendo em todos os estados do Brasil e em diversas formações vegetais (BFG 2015). Na SGLA, a espécie foi encontrada em área com fitofisionomia de cerrado stricto sensu.

13. Hexasepalum Bartl. Ex DC., Prodr. 4:561. 1830. Ervas ou subarbustos. Ramos eretos ou escandentes. Folhas opostas, sésseis; estípula fimbriada; lâmina elíptica, ovada ou lanceolada. Inflorescência em glomérulos axilares. Flores sésseis; cálice 4-lobado, persistente no fruto; corola 4-lobada, infundibuliforme, lilás a alva; anteras ovadas; ovário bilocular, lóculos um ovulado, estigma capitado. Fruto esquizocárpico, 2-mericarpos, caducos quando maduro. Semente plano-convexa, sulcada ventralmente.

Hexasepalum é um gênero com ca. 11 espécies, distribuídas ao longo do continente americano e África (Bacigalupo \& Cabral 2007; Govaerts et al. 2016). Na SGLA, Diodella está representada por duas espécies e caracteriza-se por apresentar inflorescência em glomérulos axilares, corola infundibuliforme, estigma capitado e fruto esquizocárpico composto por dois mericarpos e semente plano-convexa (Cabral \& Bacigalupo 2005).

\section{Chave de identificação para as espécies de Hexasepalum}

1. Lâmina foliar elíptica, ápice agudo, superfície bulada (nervada pregueada), brácteas elípticas, lobos do cálice $3,1 \mathrm{~mm}$ compr. Hexasepalum radula

1'. Lâmina foliar lanceolada, ápice acuminado, superfície lisa (nervação inconspícua), brácteas lanceoladas a ovadas, lobos do cálice $1,5 \mathrm{~mm}$ compr. Hexasepalum teres

13.1. Hexasepalum radula (Willd.) Delprete \& J.H. Kirkbr., J. Bot. Res. Inst. Texas 9(1): 105. 2015.

Fig. 6a,b

Subarbusto até $40 \mathrm{~cm}$ alt. Ramos angulados, estriados, vináceos, esfoliantes, setosos. Estípula 7-fimbriada, setosa, bainha 1,9-2,3 mm compr., fímbrias linear-triangulares, 2,3-4,2 × 0,2-0,5 mm; lâmina elíptica, ápice agudo, base truncada, ca.
$1,7 \times 0,8 \mathrm{~cm}$, bulada, cartácea, discolor, estrigosa. Glomérulo 3-muitas flores; brácteas elípticas, foliáceas, 1,8-2,5 × 1,1-1,4 cm, verdes, estrigosas. Lobos do cálice estreitamente triangulares, ca. 3,1 1 mm, verde, estrigosos; corola ca. $8 \mathrm{~mm}$ compr., tubo ca. 5,2 mm compr., alvo a lilás, setoso externamente, piloso internamente, lobos triangulares, ápice agudo, lilás, setosos 
externamente; anteras ca. $2 \times 1 \mathrm{~mm}$, alvas, glabras; estilete ca. 9,5 mm compr., alvo, glabro, estigma ca. 0,3 mm compr., papiloso. Fruto ca. 2,6 × 3,4 $\mathrm{mm}$, verde-enegrecido, mericarpo obovoide, 2,6-2,7 × 2,4-2,5 mm, piloso. Semente 1,9 × 1,3 $\mathrm{mm}$, ferrugínea.

Material examinado: Licínio de Almeida, Rodovia para Urandi ca. $3,8 \mathrm{~km}$ da cidade de Licínio de Almeida, 14'71'30'S, 4250'91'W, J. Jardim et al. 3317 (ALCB, CEPEC, HUEFS); Rodovia para Urandi, 9.XII.2009, fl., 1443'9'S, 42'30'50'W, E. Melo et al. 7346 (HUEFS); Pedra Preta, 27.X.2012, fl., 1475'16,7'S, 4254'41'W, N. Roque et al. 3757 (ALCB); Trilha Santana para o cascarrento, 6.II.2013, fl., 1458'8'S, N. Roque et al. 3499 (ALCB); Trilha para o Cachoeirão, 20.VII.2012, fl. e fr., 1441'25,6”'S, 42³2'34,3”'W, R.L. Borges et al. 66 (ALCB); Campo rupestre do Xaxá, 23.I.2015, fl. e fr., 14³9'11''S, 42³3'03,4”W, R.L. Borges et al. 236 (ALCB, CEPEC, HUEFS); Saco da Onça, 14.V.2015, fl. e fr., 1446'16"S, 42³4'16"W, R.L. Borges et al. 299 (ALCB, CEPEC, HUEFS).

Material adicional examinado: Caetité, 15.VII.2001, fl., 140'12,5"S, 42²8'44"W, V.C. Souza et al. 26067 (HUEFS).

Hexasepalum radula é uma espécie amplamente distribuída, ocorrendo no Brasil, Equador e Venezuela (Cabral \& Bacigalupo 2005). No Brasil, Hexasepalum radula está associada a diversos domínios fitogeográficos e fitofisionomias (BFG 2015). Na SGLA, a espécie ocorre em áreas antropizadas diferenciando-se de $H$. teres por apresentar ramos setosos (vs. ramos estrigosos), lâmina foliar elíptica (vs. lâmina foliar lanceolada a ovada), ápice acuminado (vs. ápice agudo) e superfície foliar nervada pregueada ( $v s$. superfície foliar lisa).

13.2. Hexasepalum teres (Walter) J.H. Kirkbr., J. Bot. Res. Inst. Texas 80(1): 17. 2014. Fig. 6c Arbusto ca. $20 \mathrm{~cm}$ alt. Ramos angulados, estriados, esfoliantes, setosos. Estípula 8-fimbriada, setosa, bainha 1,7-2,3 mm compr., fimbrias lineares, 3,6-7 × 0,2-0,4 mm; lâmina lanceolado-ovada, ápice acuminado, base truncada, 1,4-1,8 × 0,5-0,7 cm, lisa, cartácea, discolor, estrigosa. Glomérulo paucifloro, ca. 2-flores; brácteas lanceolado-ovadas, foliares, $0,8-0,9 \times 0,3-0,4 \mathrm{~cm}$, verde, estrigosas. Lobos do cálice triangulares, $1,5 \times 1 \mathrm{~mm}$, verde, estrigosos; corola ca. $7 \mathrm{~mm}$ compr., tubo ca. 5 mm compr., alvo-lilás, puberulento externamente, piloso internamente, lobos triangulares, 3,1 $\times 2$ $\mathrm{mm}$, ápice agudo, puberulentos externamente, glabros internamente; antera $1,8 \times 1 \mathrm{~mm}$, alva, glabra; estilete $7,8 \mathrm{~mm}$ compr., alvo, glabro, estigma capitado ca. $0,5 \mathrm{~mm}$ compr. Fruto ca. 3-3,3 $\times 2,6-3,2 \mathrm{~mm}$, verde a castanha, mericarpo plano convexo, glabro. Semente $2,7 \times 2,2 \mathrm{~mm}$, ferrugínea.

Material examinado: Licínio de Almeida, Rodovia para Urandi, 31.III.2001, fl. e fr., 1442'47'S, 42³0'33”W, J.G. Jardim et al. 3314 (ALCB, CEPEC, HUEFS); campo rupestre do Xaxá, 23.V.2013, fr., 14³9'09'S, 4233'5”W, R.L. Borges et al. 146 (ALCB, CEPEC). Material adicional examinado: Licínio de Almeida, Lagoa da Várzea, 11.XII.2009, fl., 14³3'53"S, 4227'52”W, E. Melo et al. 7454 (ALCB, HUEFS).

Hexasepalum teres é uma espécie amplamente distribuída, ocorrendo dos Estados Unidos a América do Sul (Cabral \& Bacigalupo 2005). No Brasil, H. teres está associada a diversas fitofisionomias, ocorrendo com grande frequência em áreas antropizadas (Cabral \& Bacigalupo 2005; BFG 2015). Na SGLA, esta espécie está associada a áreas antropizadas e borda de florestas estacionais.

\section{Ixora L., Sp. Pl. 1: 110. 1753.}

Arbustos ou árvores. Ramos eretos, cilíndricos. Folhas opostas, pecioladas, sésseis ou subsésseis; estípula inteira, ápice aristado; lâmina foliar elíptica, oblonga ou obovada. Inflorescência em corimbo, tirso ou panícula terminal. Flores pediceladas a sésseis; cálice 4-lobado; corola 4-lobada, hipocrateriforme, anteras elípticas, lineares ou oblongas; ovário bilocular, lóculos um ovulado, estigma bífido. Fruto carnoso, drupáceo, globoso a subgloboso, verde a atropurpúreo. Semente plana convexa.

Ixora é um gênero pantropical com ca. 350 espécies (De Block 1998), das quais ca. 37 ocorrem no Brasil (BFG 2015). O gênero caracteriza-se por apresentar estípula triangular aristada, flores 4-lobadas e frutos globosos a subglobosos.

14.1. Ixora brevifolia Benth., Linnaea 23: 448. 1850 .

Fig. 7a,b

Árvore até $6 \mathrm{~m}$ alt.. Ramos cilíndricos, estriados, puberulentos a glabrescentes. Folhas opostas, pecioladas (pecíolo 6,9-7,8 $\mathrm{mm}$ compr.); estípula triangular, 5,2 $\times 3 \mathrm{~mm}$, glabra externamente, puberulenta internamente; lâmina elíptica, ápice acuminado, base atenuada, 6,5-10,5 $\times$ 2,3-3,4 cm, lisa, cartácea, discolor, glabra. Tirso terminal, pedunculado (pedúnculo 1,2-2,1 cm compr.); brácteas lanceoladas, 2,1-2,5 × ca. $0,5 \mathrm{~mm}$, ferrugíneas, glabras externamente, puberulentas internamente. Flores subsésseis 
(pedicelo ca. 0,3 mm compr.), aromáticas; lobos do cálice triangulares, ca. $0,4 \times 0,7 \mathrm{~mm}$, verdes, glabros; corola ca. 4,7 mm compr., tubo ca. $2 \mathrm{~mm}$ compr., creme, glabro externamente, tomentoso internamente, lobos da corola oblongos, ápice arredondado, cremes, glabros; anteras elípticas ca. $3 \times 0,9 \mathrm{~mm}$, cremes, glabras; estilete 4-4,7 mm compr., alvo a creme-esverdeado, lobos do estigma ca. 1,2 mm compr., glabros. Fruto subgloboso, 4,1-5,1 × 4-4,1 mm, verde a atropurpureo, liso, glabro. Semente ca. 3,9 $\times$ 4,1 mm, marrom, lisa. Material examinado: Licínio de Almeida, Riacho fundo, 22.V.2013, fr., 14³3'11,6”S, 42³2'32,8’W, R.L. Borges et al. 137 (ALCB, CEPEC, HUEFS, RB); Mata após Campo rupestre do Xaxá, 21.I.2015, fl., 14³8'44,5”S, 42³3'17,8'W, R.L. Borges et al. 242 (ALCB, CEPEC, HUEFS, RB).

Ixora brevifolia é uma espécie de ampla distribuição, ocorrendo nos domínios da Caatinga e Cerrado, associada às fitofisionomias de floresta estacional (Delprete 2003; BFG 2015). Na SGLA, I. brevifolia está associada a áreas de floresta estacional, caracterizando-se por apresentar hábito arbóreo, flores cremes, aromáticas e frutos subglobosos (verdes quando imaturos a atropurpúreo quando maduros).

15. Manettia Mutis, Mant. Pl. Altera 553: 558.1771.

Trepadeiras. Ramos volúveis, angulares a cilíndricos. Folhas opostas, pecioladas; estípula inteira; lâmina cordada, lanceolada a ovada. Inflorescência em dicásio, monocásio ou tirso, axilar, pedunculada. Flores pediceladas; cálice 4-8 lobado; corola 4-5 lobada, hipocrateriforme; anteras elípticas ou oblongas; ovário bilocular, lóculos pluriovulados, estigma bífido. Fruto seco, capsular, septicida, elipsoide, oblongo ou ovóide, verde a castanho. Semente alada.

Manettia é um gênero neotropical apresentando entre 80 e 123 espécies (Marinero et al. 2012). No Brasil, ocorrem 27 espécies distribuídas em diversos domínios fitogeográficos e fitofisionomias (BFG 2015). O gênero caracteriza-se por apresentar hábito trepador, frutos capsulares e sementes aladas.

15.1. Manettia cordifolia Mart., Spec. Mat. Med. Bras. 1: 19. 1824. Figs. 5j,k; 7c-e

Ramos cilíndricos, estriados, setosos. Folhas opostas, pecioladas (pecíolo 1,2-8 mm compr.); estípula amplamente triangular, ca. 1,5 × $3 \mathrm{~mm}$, setosa; lâmina lanceolada a ovada, ápice acuminado, base arredondada-atenuada, 4,3-6,1 × 1-2,9 cm, lisa, membranácea, discolor, setosa. Dicásios ou tirsos axilares, pedunculados (pedúnculo 2-2,4 mm compr.); brácteas ovadas, foliáceas, 1-2 × 0,7-1 $\mathrm{mm}$, verdes, setosas. Flores pediceladas (pedicelo 11,7-18,2 mm compr.); cálice 4-lobado, lobos do cálice triangulares, 2,4-4,5 × 1,3-2 mm, verdes, setosos; corola 4,6-5,5 cm compr., tubo ca. $4 \mathrm{~cm}$ compr., vermelho, glabro externamente, tomentoso internamente; lobos da corola deltados, ápice agudo, vermelhos, glabros; anteras elípticas, ca. $5 \times 2,1$ $\mathrm{mm}$, roxas a azuis, glabras; estilete ca. $3,6 \mathrm{~cm}$ compr., verde, glabro, lobos do estigma ovóides, papilosos. Fruto ovoide, ca. 11,5 ×6,5 mm, verde a castanho quando maduro, setoso. Semente 3,5-4,1 $\times 1,8-2,5 \mathrm{~mm}$, negra, rugosa.

Material examinado: Licínio de Almeida, Rodovia em direção a Brejinho das Ametistas, 12.III.1994, fl., 14'32'4'S, 42³1'51'W, N. Roque et al. (SPF); Fazenda São Domingos, 10.XII.2009, fl., 14²7'05'S, 42.31'30"W, M.L. Guedes et al. 16752 (ALCB, HUEFS); Riacho Fundo, 19.VII.2012, fl., 14³3'11,6”S, 42'32'32,8”W, R.L. Borges et al. 44 (ALCB); Trilha para o Cascarrento, 20.VII.2012, fl. e fr., 1441'25,6"S, 42`32'34,3”W, R.L. Borges et al. 58 (ALCB); Trilha ao lado da cachoeira das sete quedas, 22.V.2013, fl. e fr., 14³1'1,5'S, 42³2'W, R.L. Borges et al. 132 (ALCB, CEPEC, HUEFS); Lameirão para trilho do trem, 22.II.2014, fl., 1469'36”S, 4253'53'W, N. Roque et al. 4174 (ALCB); Mata ciliar do Xaxá, 28.V.2014, fl. e fr., 1441'3'S, 42³2'44'W, R.L. Borges et al. 197 (ALCB, HUEFS); Fazenda Xaxá, 7.VII.2014, fl., 1465'58"S, 42'54'69'W, M.L. Guedes et al. 22168 (ALCB); Área antropizada do Xaxá, 12.V.2015, fl. e fr., 14³9'11''S, 42³3'13,4”W, R.L. Borges et al. 273 (ALCB, CEPEC, HUEFS).

Material adicional examinado: Caetité, ca. $14 \mathrm{~km}$ ao norte de Caetité em direção a Mamiaçu, 12.IV.2005, fl., 135'22”'S, 42²7'36”W, E.B. Miranda et al. 753 (HUEFS).

Manettia cordifolia é uma espécie amplamente distribuída, ocorrendo nos domínios Amazônico, Caatinga, Cerrado e Floresta Atlântica (BFG 2015). Na SGLA esta espécie está associada a áreas antropizadas e bordas de mata. $M$. cordifolia caracteriza-se por apresentar hábito trepador, lâmina foliar ovada a lanceolada, flores vermelhas e sementes aladas negras.

16. Margaritopsis C.Wright, Anales Acad. Ci. Méd. Habana 6: 146. 1869.

Arbustos, subarbustos ou árvores. Ramos eretos, cilíndricos ou costados. Folhas opostas, pecioladas; estípula inteira ou bífida; lâmina foliar elíptica a ovada. Inflorescência em tirsos, dicásios ou umbeliforme, capitada, terminal, séssil ou pedunculada. Flores 5-lobadas, 
sésseis ou pediceladas; cálice 4-lobado; corola infundibiliforme, creme a amarela; anteras elipsoides ou oblongas; estilete glabro, estigma bífido. Fruto drupáceo, elipsoide a subgloboso, vermelho quando maduro. Semente plano convexa, sulcada.

Margaritopsis é um gênero pantropical com ca. 50 espécies, 27 das quais ocorrem nos Neotrópicos (Taylor 2005). No Brasil ocorrem 15 espécies, distribuídas principalmente ao longo dos domínios Amazônico e da Mata Atlântica (BFG 2015). Margaritopsis caracteriza-se por apresentar inflorescências capitadas, frutos carnosos vermelhos quando maduros e sementes planoconvexas, sulcadas.

16.1. Margaritopsis carrascoana (Delprete \& Souza) Taylor \& Souza, Syst. \& Geogr. Pl. 75(2): 171. 2005.

Fig. $7 f, g$

Subarbusto ou arbusto entre 40-80 cm alt. Ramos cilíndricos, eretos, estriados, glabros. Folhas pecioladas (pecíolo 1,8-2,6 mm compr.); estípula inteira, triangular, 1.4-1,7 × 1,6-1,9 mm, glabra; lâmina elíptica, revoluta, ápice agudo, base decorrente, 2,6-5 × 0,7-1,1 cm, lisa, cartácea, discolor, glabra. Inflorescência uniflora ou biflora, pedunculada (pedúnculo ca. 1,5 mm compr.); brácteas estreitamente triangulares, ca. $0,7 \times$ 0,1 mm, verdes, puberulentas. Flores 5-lobadas, subsésseis (pedicelo 0,3-0,6 mm compr.); lobos do cálice triangulares, $1-2,3 \times 0,5-1,2 \mathrm{~mm}$, verdes, glabros; corola infundibiliforme, 1,5-3 mm compr., tubo 0,9-1,2 mm compr., amarelo, glabro externamente, tomentoso internamente, lobos triangulares, ápice agudo, amarelo, glabro; anteras oblongas, $0,9 \times 0,3 \mathrm{~mm}$, cremes, glabras; estilete ca. 0,7-1,2 mm compr., alvo, papiloso, lobos do estigma ca. 1,2 mm compr., papilosos. Fruto elipsoide, ca. $4,8 \times 3,8 \mathrm{~mm}$, verde a vermelho, glabro. Semente ca. 4,2 ×3,7 mm, castanha, glabra. Material examinado: Licínio de Almeida, Fazenda Riacho de Areia, 22.I.2015, fl., 14 ${ }^{\circ} 45^{\prime} 32,5^{\prime} \mathrm{S}$, 42'34'38,3'W, R.L. Borges et al. 214 (ALCB, CEPEC, HUEFS); Mata estacional após o campo rupestre do Xaxá, 21.I.2015, fr., 14³8'44,5”S, 42³3'17,8”'W, R.L. Borges et al. 244 (ALCB, CEPEC, HUEFS).

Material adicional examinado: Licínio de Almeida, Estrada Caculé, fr., 1438'29”S, 42²7'41'”W, J.G. Jardim et al. 3262 (CEPEC, HUEFS).

Margaritopsis carrascoana é uma espécie endêmica do Brasil, ocorrendo na região Nordeste, em áreas de floresta estacional e campos rupestres (Taylor 2005). M. carrascona apresenta hábito arbustivo, caracterizando-se por apresentar folhas revolutas, estípula triangular, flores cremes e fruto elipsoide. Na SGLA, M. carrascoana ocorre em áreas de campo rupestre e floresta estacional.

17. Mitracarpus Zucc., Mant. 3: 210. 1827.

Arbustos ou ervas. Ramos eretos ou decumbentes, cilíndricos ou angulados. Folhas opostas ou pseudoverticiladas, sésseis a pecioladas; estípula fimbriada; lâmina elíptica, lanceolada, linear ou ovada. Inflorescência em glomérulo, terminal ou axilar. Flores sésseis ou subsésseis; cálice 4-lobado, persistente no fruto, duas sépalas maiores e duas menores, opostas; corola 4-lobada, hipocrateriforme ou infundibuliforme; anteras oblongas a lineares; ovário bilocular, lóculos um ovulado, estigma bífido. Fruto capsular, seco, deiscência circuncisa, transversal, separando a porção superior do fruto com o cálice (mitra) e porção basal persistente no glomérulo. Semente oblonga ou globosa, reticulada-foveolada, dorsalmente com sulco cruciforme ou não sulcada, ventralmente com depressão em forma de X ou Y.

Mitracarpus é um gênero neotropical, compreendendo ca. 50 espécies. No Brasil são registrados 28 espécies, distribuídas em todos os domínios fitogeográficos e fitofisionomias. O gênero caracteriza-se por apresentar flores com corola 4-lobada, fruto capsular com deiscência circuncisa, porção apical do fruto desprendendose em forma de mitra e semente apresentando depressão ventral em X ou Y (Souza et al. 2010).

17.1. Mitracarpus baturitensis Sucre, Rodriguésia 26(38): 255. 1971.

Figs. 51-n; 7h,i

Ervas ca. $30 \mathrm{~cm}$ alt.. Ramos estriados, esfoliantes, setosos a glabrescentes. Folhas opostas, sésseis; estípula 5-7 fimbriada, setosa, bainha ca. $2 \mathrm{~mm}$ compr., fimbrias linear-triangulares, 3,2-3,5 $\times$ 0,4-0,6 mm; lâmina elíptica, ápice agudo, base truncada, 2,5-4,4 ×0,8-1,3 cm, lisa, membranácea, discolor, puberulenta na face adaxial, setosa na face abaxial. Glomérulo terminal a axilar; brácteas elípticas, foliáceas, $0,8-1,9 \times 0,4-0,8$ $\mathrm{cm}$, verdes, puberulentas na face adaxial, setosas na face abaxial. Flores sésseis; lobos do cálice estreitamente triangulares, 2,6 $\times 0,5 \mathrm{~mm}$, verde, setosos na margem; corola 4-4,7 mm compr., tubo ca. 3,2 mm compr., alvo, puberulento externamente, glabro internamente, lobos triangulares ca. $1 \times 1$ $\mathrm{mm}$, ápice agudo, alvos, puberulentos em ambas as faces; antera estreitamente oblonga ca. $1 \times 0,2$ $\mathrm{mm}$, amarela, glabra; estilete $4-5 \mathrm{~mm}$ compr., alvo, glabro, lobos do estigma ca. 0,4 mm compr., 
papilosos. Fruto ca. 1,3 mm compr., verde a castanho, puberulento. Semente globosa ca. $1 \times$ 0,7 mm, depressão dorsal cruciforme, depressão ventral em X, marrom, foveolada, glabra.

Material examinado: Licínio de Almeida, Campo rupestre do Xaxá, 23.IV.2013, fl. e fr., 14³9'8,7'S, 4233'5,3"W, R.L. Borges 239 (ALCB, CEPEC, HUEFS); Riacho fundo, 6.VIII.2014, fl., 1458'69,4”'S, 4254'W, N. Roque et al. 4416 (ALCB).

Mitracarpus baturitensis é uma espécie restrita ao Brasil, ocorrendo em afloramentos rochosos da Caatinga e Cerrado (Souza et al. 2010). Na SGLA, esta espécie ocorre em floresta estacional decidual e áreas antropizadas, caracterizando-se por apresentar, estípula fimbriada, flores alvas, frutos com deiscência transversal circuncisa e sementes com depressão dorsal cruciforme, e depressão ventral em X.

18. Palicourea Aubl., Hist. Pl. Guiane 1: 172. 1775. Arbustos. Ramos eretos, cilíndricos ou angulares. Folhas opostas ou verticiladas, pecioladas; estípula bífida; lâmina foliar elíptica a ovada. Inflorescência em panícula ou tirsos terminais, pedunculada. Flores pediceladas a sésseis; cálice 5-lobado; corola 5-lobada, infundibuliforme, gibosa na base; anteras oblongas; ovário bilocular, um óvulo por lóculo, estigma bífido. Fruto carnoso, drupáceo, globoso, subgloboso ou obovoide, verde, vermelho a purpúreo-nigrescente. Semente plano convexa, sulcada dorsalmente.

Palicourea é um gênero neotropical com ca. 200 espécies, concentrado principalmente em áreas de floresta úmida (Taylor 1997). No Brasil são registradas 56 espécies, distribuídas principalmente ao longo do domínio Amazônico, Atlântico e Cerrado (BFG 2015). O gênero é estreitamente relacionado à Psychotria diferenciando-se deste pelas flores com corola gibosa.

18.1. Palicourea rigida Kunth, Nov. Gen. Sp. 3: 370. 1818.

Figs. 5o; $7 \mathrm{j}-1$

Arbusto ca. 1,5 m alt. Ramos cilíndricos, estriados, puberulentos. Folhas pecioladas (pecíolo 1,8-4,1 mm compr.); estípula puberulenta, bainha estipular 1,4-2,5 mm compr., lobos triangulares, 3-3,4 × 1,9-4,4 mm; lâmina largamente elíptica, ápice arredondado, base arredondada a atenuada, 7,5-12,9 × 5,2-8,2 cm, lisa, coriácea, discolor, puberulenta. Tirso terminal, pedunculado (pedúnculo 7,4-9,5 cm compr., vermelho-vináceo); brácteas estreitamente triangulares, 1,6-4,3 $\times$ 0,7-1,3 mm, ferrugíneas, puberulentas. Flores subsésseis a pediceladas (pedicelo 0,8-1,3 cm compr.); lobos do cálice largamente triangulares, $0,4 \times 1,2 \mathrm{~mm}$, verde, puberulentos; corola 0,6-1,1 cm compr., tubo 0,4-1 cm compr., amarelo, puberulento externamente, tomentoso internamente, lobos triangulares, ápice agudo, amarelos, puberulentos externamente, papilosos internamente; anteras 3-3,1 $\times 0,5-0,8 \mathrm{~mm}$, amarelas, puberulentas; estilete ca. $4 \mathrm{~mm}$ compr., amarelo, glabro, lobos do estigma ca. $1 \mathrm{~mm}$ compr, papilosos. Fruto globoso, ca. 3,7 × 3,5 mm, verde a vináceo, puberulento. Semente ca. $3,7 \times 3 \mathrm{~mm}$, castanha, glabra.

Material examinado: Licínio de Almeida, Trilha para a cachoeira das Sete Quedas, 12.I.2011, fl., 14²7'30"S, 42 50'91,6"W, F.A. Santana 09 (ALCB); Capim Vermelho, 24.II.2012, fr., 1466'41'S, 4250'55'W, F. Hurbath et al. 229 (ALCB); Fazenda Riacho de Areia, 20.I.2015, fl. e fr., 1445'32,5”S, 42³4'38,3”W, R.L. Borges et al. 215 (ALCB, CEPEC, HUEFS).

Palicourea rígida é uma espécie amplamente distribuída, ocorrendo em diversas formações vegetais do país e com centro de diversidade em áreas de Cerrado (BFG 2015). Na Cadeia do Espinhaço e, mais especificamente na SGLA, a espécie ocorre em áreas de campos rupestres. $P$. rigida caracteriza-se por apresentar folha coriácea eliptica e flores com corola gibosa amarela.

19. Posoqueria Aubl., Hist. P1. Guiane 1: 133. 1775. Arbusto ou árvore. Ramos eretos, angulares ou cilíndricos. Folhas opostas, pecioladas; estípula inteira, navicular; lâmina foliar elíptica, lanceolada, oblonga ou ovada. Inflorescência em corimbo, terminal, pedunculada. Flores pediceladas; cálice 5-lobado; corola 5-lobada, longa tubular, hipocrateriforme; anteras lineares a lanceoladas; ovário bilocular, lóculos pluriovulados, estigma bífido. Fruto carnoso, bacáceo, verde a amarelo. Semente cuneiforme, glabra.

Posoqueria é um gênero Neotropical, com ca. 22 espécies, distribuindo-se do sul do México ao Sul do Brasil (Macias 1988; Govaerts et al. 2016). No Brasil são registradas 10 espécies distribuídas principalmente nos domínios Atlântico e Cerrado. O gênero caracteriza-se por apresentar inflorescência corimbiforme, flor hipocrateriforme, longo tubular e frutos carnosos drupáceos.

19.1. Posoqueria latifolia (Rudge) Roem. \& Schult., Syst. Veg. 15(5): 227. 1819.

Árvore ca. $4 \mathrm{~m}$ alt. Ramos cilíndricos, estriados, puberulentos a glabrescentes. Folhas opostas, pecioladas (pecíolo 3,1-4,9 mm compr.); 
estípula ovada, navicular, 1,1-1,2 × 0,6-0,7 cm, glabra; lâmina elíptica, ápice agudo a arredondado, margem inteira, base arredondada, 7,7-11,5 $\times$ 3,2-7,3 cm, lisa, coriácea, discolor, glabra. Inflorescência pedunculada (pedúnculo 1-2,5 cm compr.); brácteas triangulares, ca. $2 \times 0,8 \mathrm{~mm}$, ferrugíneas, glabras. Flores pediceladas (pedicelo 1-2,2 cm compr.); lobos do cálice deltados, ca. 2 $\times 2 \mathrm{~mm}$, verdes, puberulentos na margem; corola 13-14,8 cm compr., tubo 11,8-12,6 cm compr., alvo, glabro, lobos oblongos, ápice arredondado, alvos, glabros; anteras 6-7 × 1,8-2 mm, cremes, estrigosas; estilete ca. $7 \mathrm{~cm}$ compr., alvo, glabro, lobos do estigma ca. 1,6 mm compr., papilosos. Fruto globoso ca. $3 \times 3 \mathrm{~cm}$ glabro. Semente ca. 1,2-1,4 × 0,9-1 cm, castanha avermelhada, lisa.

Material examinado: Licínio de Almeida, Trilha para o Cachoeirão, 20.VII.2012, fr., 1441'20,1”S, 42'32'34,3"W, R.L. Borges et al. 65 (ALCB, CEPEC, HUEFS).

Material adicional examinado: Rio do Pires, Campo do cigano, 5.XII.2000, fl., 13²6'38'S, 41'91'94'W, F.H. Nascimento 423 (ALCB); Rio de Contas, Mata da base do Pico do Itobira, fl., 1357'89'S, 41'81'14'W, F.H. Nascimento 102 (CEPEC).

Posoqueria latifolia é uma espécie amplamente distribuída, ocorrendo em todos os domínios fitogeográficos do Brasil, e está associada a florestas estacionais, florestas úmidas e restingas (Macias 1988). Na SGLA, P. latifolia é encontrada em floresta estacional, caracterizandose por apresentar lâmina foliar elíptica, estípula interpeciolar ovada-triangular, navicular.

\section{Psychotria L., Syst. Nat. 10(2): 929. 1759}

Arbustos ou árvores. Ramos eretos, cilíndricos. Folhas opostas, sésseis a pecioladas; estípula persistente, bífida ou inteira; lâmina foliar elíptic. Inflorescência em panícula ou tirso, terminal, raramente axilar, séssil a pedunculada. Flores pediceladas a sésseis; cálice 4-5-lobado; corola 4-5-lobada hipocrateriforme; anteras oblongas; ovário bilocular, lóculos um ovulado, estigma bífido. Fruto carnoso, drupáceo, 2-seminado, elipsoide ou subgloboso, verde a vermelho, alaranjado ou nigrescente quando maduro. Semente plano convexa, apresentando sulcos dorsais.

Psychotria é um gênero pantropical com ca. 1.000 espécies, das quais ca. 500 ocorrem nos Neotrópicos (Taylor 2007). No Brasil ocorrem 252 espécies, distribuídas principalmente ao longo dos domínios Atlântico e Amazônico (BFG 2015). Na SGLA, Psychotria está representada por três espécies, associadas a áreas de floresta estacional e cerrado sensu stricto. O gênero caracteriza-se por apresentar flores geralmente alvas, estípula bífida ou inteira, frutos drupáceos e semente plana convexa.

\section{Chave para as espécies de Psychotria}

1. Árvores; estípula inteira; flores pediceladas (pedicelo 2,2-6,3 mm compr.); fruto laranja a vermelho quando maduro. Psychotria mapourioides

1'. Arbustos; estípula bífida; flores sésseis; fruto atropurpúreos quando maduro.

2. Lobos estipulares $0,8-1,3 \mathrm{~cm}$ compr.; pecíolo 2,1-3,5 cm compr., lâmina 8,1-8,9 cm compr., domacias ausentes, nervura central (face abaxial) pilosa Psychotria capitata

2'. Lobos estipulares 0,08-0,16 cm compr.; pecíolo 1,4-1,5 mm compr., lâmina 3,2-5,7 cm compr., domacias na face abaxial, nervura central (face abaxial) glabra. Psychotria rupestris

20.1. Psychotria capitata Ruiz. \& Pav., Fl. Peruv. 2: 59, 206. 1799.

Fig. $8 h-j$

Arbusto 1-1,5 m alt. Ramos cilíndricos, estriados, estrigulosos. Folhas pecioladas (pecíolo 2,1-3,5 cm compr.); estípula bífida, glabra, bainha 1,8-3,3 mm compr., lobos triangulares 8,4-13 $\times$ 1-2 mm; lâmina elíptica, ápice acuminado, base arredondada, 8,1-8,9 × 2,3-4,2 cm, lisa, cartácea, discolor, pilosa apenas ao longo da nervura central da face abaxial. Tirso terminal, pedunculado (pedúnculo 25,6-45,3 mm compr.), piloso a glabrescente; brácteas lanceoladas,
4,8-8,6 × 1,6-2,1 mm, verdes, glabras. Flores sésseis; lobos do cálice triangulares, ca. 0,6 60,8 $\mathrm{mm}$, verdes, glabros; corola hipocrateriforme, ca. $6,7 \mathrm{~mm}$ compr., tubo ca. 5,6 mm compr., alvo, glabro externamente, tomentoso internamente, lobos triangulares, ápice agudo, alvos, estrigosos externamente, papilosos internamente; anteras ca. $1 \times 0,3 \mathrm{~mm}$ compr., alvas, glabras; estilete ca. 2,6 mm compr., alvo, glabro, lobos do estigma ca. 1,9 $\mathrm{mm}$ compr. Fruto subgloboso, ca. 4,6 $\times 5,9 \mathrm{~mm}$, atropurpúreo quando maduro, glabro. Semente $5 \times$ $3 \mathrm{~mm}$, creme, sulcada. 
Material examinado: Licínio de Almeida, Estrada para Caetité, 3.XI.2006, fr., 1453'75”S, 4253'11'W, A. Rapini 1324 (HUEFS); Trilha para Casacarrento, 10.V.2012, fl. e fr., 14'34'51'"S, 42'33'40'W, N. Roque et al. 3489 (ALCB, CEPEC, HUEFS); Trilha após o Cachoeirão, 22.I.2013, fr., 1442'02”S, 42³3'38,3”W, R.L. Borges et al. 089 (ALCB, HUEFS); Saco da Onça, 5.IV.2013, fr., 1446'15,7'S, 42³4'15,8'W, R.L. Borges et al. 114 (ALCB, HUEFS); Trilha do Lameirão para trilho do trem, 22.II.2014, fr., 1441'37, '"S, 42³2'7,5' W, N. Roque et al. 4183 (ALCB, CEPEC, HUEFS); Mata do Riacho de Areia, 20.I.2015, fr., 1446'54,7'S, 42³4'4,9'W, R.L. Borges et al. 221 (ALCB, CEPEC, HUEFS); Santa Clara, 22.I.2015, fr., 14²9'52,1'S, 42³2'44,8”W, R.L. Borges et al. 268 (HUEFS).

Psychotria capitata é uma espécie amplamente distribuída, ocorrendo em diversas formações vegetais no Brasil (BFG 2015). Na Cadeia do Espinhaço e, mais especificamente na SGLA, a espécie ocorre em áreas de floresta estacional. $P$. capitata se caracteriza por apresentar estípula bífida com lobos 8,4-13 mm compr. (vs. lobos 0,8-1,6 mm compr. em P.rupestris), folhas não apresentando domacias (vs. folhas com domacias).

20.2. Psychotria mapourioides DC., Prodr. 4: 509. 1830.

Fig. $8 \mathrm{k}-\mathrm{m}$

Árvore ca. $8 \mathrm{~m}$ alt. Ramos cilíndricos, estriados, lenticelados, glabros. Folhas pecioladas (pecíolos 1-2,6 cm compr.), estipula inteira, obovada-eliptica, $1-1,8 \times 0,4-0,7 \mathrm{~cm}$, glabra; lâmina elíptica a largamente elíptica, ápice agudo, base atenuada, 13,2-17 ×5,2-7,1 cm, lisa, coriácea, discolor, glabra, apresentando domacias na superfície abaxial entre a nervura central e laterais. Tirso terminal, pedunculado (pedúnculo 3,4-7,1 cm compr.); brácteas triangulares, ca. $0,8 \times 1 \mathrm{~mm}$, ferrugíneas, estrigosas. Flores pediceladas (pedicelo 2,2-6,3 mm compr.); lobos do cálice fusionados, 0,7-1 mm compr., verdes, puberulentos; corola ca. 7,4 mm compr., tubo 3,3-5,1 mm compr., alvo, glabro externamente, tomentoso internamente, lobos triangulares, ápice agudo, alvos, estrigulosos externamente, tomentosos internamente; anteras 2,2-2,3 × 0,6-0,7 mm, alvas, glabras; estilete ca. 2,9 mm compr., alvo, glabro, lobos do estigma ca. 4,2 mm compr. Fruto globoso 4-4,7 × 3,7-4,5 $\mathrm{mm}$, verde a vermelho, glabro. Semente ca. 5,9 $\times$ $4 \mathrm{~mm}$, creme.

Material examinado: Licínio de Almeida, Lameirão, 21.I.2013, fl. e fr., $14^{\circ} 41^{\prime} 35,5^{\prime}$ 'S, 42³2'47,7’W, R.L. Borges et al. 87 (ALCB, HUEFS).

Psychotria mapourioides é uma espécie endêmica do Brasil, ocorrendo nos domínios
Amazônico, Atlântico e Cerrado (BFG 2015). $\mathrm{Na}$ SGLA, foi encontrada em áreas de floresta estacional. Psychotria mapourioides diferenciase das demais por apresentar hábito arbóreo ( $v s$. hábito arbustivo), ramos com lenticelas (ausente em $P$. capitata e $P$. rupestris); estípula inteira ( $v s$. estipula bífida); flores pediceladas (vs. sésseis) e fruto vermelho a alaranjado quando maduro ( $v s$. atropurpúreos).

20.3. Psychotria rupestris Müll. Arg., Flora 59: 542, 546. 1876.

Arbustos até. $1 \mathrm{~m}$ alt. Ramos cilíndricos, estriados, puberulentos. Folhas pecioladas (pecíolo 1,4-1,5 mm compr.); estípula bífida, puberulenta, bainha ca. $0,7 \mathrm{~mm}$ compr., lobos triangulares, 0,8-1,6 × 0,3-0,5 mm; lâmina elíptica, ápice agudo, base arredondada, 3,2-5,7 × 1,4-2,4 cm, lisa, papirácea, discolor, puberulenta ao longo das nervuras, apresentando domacias na superfície abaxial entre a nervura central e laterais. Tirso terminal, pedunculado (pedúnculo 1-4 cm compr.); brácteas elípticas, foliáceas, 4-6 × 0,6-1 $\mathrm{mm}$, verdes, estrigosas. Flores sésseis; lobos do cálice triangulares, $1,1-1,3 \times 0,3-0,4 \mathrm{~mm}$ verdes, papilosos e estrigosos na margem; corola hipocrateriforme, 2,5-3 mm compr.; tubo ca. 1,2 mm compr., alvo, puberulento externamente, glabro internamente, piloso na região das anteras, lobos ovados, ápice agudo, alvo, estrigulosos externamente, papilosos internamente; anteras ca. 0,8-1 × ca. 0,4 mm, alvas, glabras; estilete ca. 1,7 mm compr., ferrugíneo, papiloso, lobos do estigma ca. 0,3 mm compr. Fruto subgloboso, ca. $3,1 \times 3,7 \mathrm{~mm}$, verde, glabro. Semente ca. $3,4 \times$ 2,4 mm, creme.

Material examinado: Licínio de Almeida, Rodovia para Urandi, 31.III.2001, fr., 1442'47'S, 42³0'33'W, J.G. Jardim et al. 3304 (ALCB, CEPEC); Santa Clara, 25.V.2013, fr., 14²9'52,1''S, 42³2'44,8'W, R.L. Borges et al. 162 (ALCB, CEPEC, HUEFS); Mata ciliar após a Fazenda Riacho de Areia, 27.V.2014, fr., 1446'54,8'S, 42³4'10,6”'W, R.L. Borges et al. 190 (ALCB, HUEFS); Mata após Campo rupestre do Xaxá, 21.I.2015, fr., 14³8'44,5'S, 42³3'17,8”W, R.L. Borges et al. 241 (ALCB, CEPEC, HUEFS). Santa Clara, 21.I.2015, fr., 14'29'52,1"S, 42'32'44,8”W, R.L. Borges et al. 162 (ALCB, CEPEC, HUEFS).

Material adicional examinado: Licínio de Almeida, Estrada para Urandi, 9.XII.2009, fl., 1444'43”S, 42'31'02”W, E. Melo et al. 7364 (ALCB, HUEFS)

Psychotria rupestris é uma espécie endêmica do Brasil, ocorrendo nos domínios Amazônico e do Cerrado (BFG 2015). Na SGLA, foi encontrada em 
áreas de floresta estacional. Psychotria rupestris diferencia-se das demais espécies do gênero na SGLA por apresentar lâmina foliar 3,2-5,7 cm compr. (vs. 8,1-17 cm compr.) e lobos estipulares 0,8-1,6 mm compr. (vs. 8,4-13 mm compr. em $P$. capitata).

21. Psyllocarpus Mart. ex Mart. \& Zucc., Flora 7(1): 130. 1824.

Ervas, arbustos ou subarbustos. Ramos eretos, ramificados ou não ramificados, angulares. Folhas opostas ou verticiladas, sésseis; estípula fimbriada (3-8 fimbrias); lâmina foliar linear. Inflorescência capituliforme, verticilastro, ou flores solitárias, terminais ou axilares, pedunculadas. Flores pediceladas a sésseis; cálice 2-lobado, persistente no fruto; corola 4-lobada, hipocrateriforme, alva a azul; anteras oblongas, inclusas na corola; ovário 2-locular, lóculos um ovulado, estigma bífido. Fruto cápsula, septicida, obovoide. Semente alada, rugosa.

Psyllocarpus é um gênero Neotropical e apresenta oito espécies com distribuição restrita ao Brasil (BFG 2015; Kirkbride 1979). O gênero caracteriza-se por apresentar hábito arbustivo ou subarbustivo; inflorescência capituliforme ou verticilastro, flores com corola 4-lobada, alvas a azuis, frutos capsulares, obovoides, expondo duas sementes aladas.

\section{Chave para as espécies de Psyllocarpus}

1. Inflorescência em verticilastro, pedúnculo 3,2-7 mm compr.; corola azul, ca. 4,5 mm compr. Psyllocarpus laricoides

1'. Inflorescência capituliforme, pedúnculo 13,6-22,6 mm compr.; corola alva, ca. 2,4 mm compr. Psyllocarpus asparagoides

21.1. Psyllocarpus asparagoides Mart. ex Mart. \& Zucc., Flora 7(1): 131. $1824 . \quad$ Figs. 8o; 9a,b

Subarbustos ca. $30 \mathrm{~cm}$ alt. Ramos angulares (4-costados), estriados, puberulentos, esfoliantes. Folhas sésseis; estípula 6-8 fimbriada, puberulenta, bainha $0,5-0,7 \mathrm{~mm}$ compr., fimbrias triangulares, 0,3-0,6 × 0,1-0,2 mm; lâmina linear, ápice agudo, base truncada, $0,5-1,2 \times 0,02 \mathrm{~cm}$, lisa, cartácea, concolor, glabra. Inflorescência capituliforme, pedunculada (pedúnculo 12,8-22,6 mm compr.); brácteas lanceoladas, foliáceas, $4,4 \times 0,4 \mathrm{~mm}$, glabras. Flores sésseis; lobos do cálice triangulares, $1,2-1,7 \times$ ca. $0,5 \mathrm{~mm}$, verdes, glabros; corola ca. 2,4 $\mathrm{mm}$ compr., tubo ca. $1,2 \mathrm{~mm}$ compr., alvo, papiloso externamente, tomentoso internamente, lobos da corola ovados, ápice agudo, alvos, puberulentos externamente, papilosos internamente; anteras ca. $0,5 \times 0,2 \mathrm{~mm}$, inclusas, alvas, glabras; estilete diminuto, ca. 0,2 mm compr., alvo, glabro; lobos do estigma $0,1-0,2 \mathrm{~mm}$ compr., papilosos. Fruto $2,5 \times 1,6 \mathrm{~mm}$, verde a castanho. Semente ca. $2,5 \times$ $1,6 \mathrm{~mm}$, castanha, glabra.

Material examinado: Licínio de Almeida, Trilha para o Cachoeirão, 12.V.2015, fl. e fr., 14\%41'18,7'S 42³3'2,6”'W, R.L. Borges et al.289 (ALCB, CEPEC, HUEFS).

Psyllocarpus asparagoides é uma espécie com distribuição restrita às altas elevações ao longo da Cadeia do Espinhaço (Minas Gerais e Bahia), ocorrendo em áreas de Cerrado sensu stricto e campos rupestres (BFG 2015; Kirkbride 1979). Na SGLA, esta espécie está associada a áreas de campos rupestres, diferenciando-se de $P$. laricoides por apresentar inflorescência capituliforme ( $v s$. inflorescência em verticilastro); flores com corola alva ( $v s$. corola azul) e corola ca. 2,4 mm compr. (vs. corola ca. $4,5 \mathrm{~mm}$ compr.).

21.2. Psyllocarpus laricoides Mart. \& Zucc. Flora 7(1): 131. $1824 . \quad$ Figs. 8o; 9c,d Subarbusto entre $30-50 \mathrm{~cm}$ alt. Ramos angulares (4-costados), estriados, glabros, esfoliantes. Folhas sésseis, estípula 6-fimbriada, bainha ca. $1 \mathrm{~mm}$ compr., fimbrias triangulares, ca. $0,8 \times 0,2 \mathrm{~mm}$; lâmina linear, ápice agudo, base truncada, $0,5-1 \times$ ca. $0,04 \mathrm{~cm}$, concolor, glabra. Inflorescência em verticilastro, terminal, pedunculada (pedúnculo ca. 3,2-7 mm compr.); brácteas lanceoladas, foliáceas, 4-4,2 $\times$ ca. 0,7 $\mathrm{mm}$. Flores sésseis; lobos do cálice lanceolados, ca. 1,7 $\times 0,6 \mathrm{~mm}$, verdes, glabros; corola ca. 4,5 $\mathrm{mm}$ compr., tubo ca. $3 \mathrm{~mm}$ compr., azul, seríceo externamente, tomentoso internamente, lobos da corola triangulares, ápice agudo, azuis, seríceos externamente, papilosos internamente; anteras $1-1,2 \times$ ca. $0,5 \mathrm{~mm}$, inclusas, alvas, glabras; estilete diminuto, ca. 0,3 mm compr., alvo, glabro; lobos do estigma ca. $0,3 \mathrm{~mm}$ compr., papilosos. Fruto $2,8-4,9 \times 2,1-2,5 \mathrm{~mm}$, verde a castanho. Semente 2-3 $\times 1-2 \mathrm{~mm}$, castanha, glabra. 
Material examinado: Licínio de Almeida, Fazenda Riacho de Areia, 24.V.2013, fl. e fr., 1445'28"S, 42'34'37,5”'W, R.L. Borges et al.154 (ALCB, CEPEC, HUEFS); Trilha Xaxá Cachoeirão, 28.V.2014, fl. e fr., 14\%41'3,5”S, 42³2'44,1"W, R.L. Borges et al. 199 (ALCB, CEPEC, HUEFS); Trilha para o Cachoeirão, 14.V.2015, fl. e fr., 1441'3,5”S, 42³2'44,1'W, R.L. Borges et al. 290 (ALCB, CEPEC, HUEFS).

Psyllocarpus laricoides é uma espécie com distribuição restrita na Cadeia do Espinhaço (BFG 2015; Kirkbride 1979). Na SGLA, esta espécie está associada a áreas de cerrado sensu stricto e campo rupestre.

22. Randia L. Sp. Pl. 2: 1119. 1753.

Arbustos ou árvores. Ramos eretos, espinescentes ou inermes, cilíndricos. Folhas opostas, pecioladas; estípula inteira; lâmina foliar elíptica ou obovada. Inflorescência em tirso a fascículo (flores masculinas) ou uniflora (flores femininas), séssil a pedunculada. Flores bissexuais ou unissexuais, pediceladas a sésseis; cálice 4-5 lobado, lobos livres ou fusionados, verdes; corola 4-5 lobada, hipocrateriforme; anteras oblongas, glabras; ovário bilocular, lóculos pluriovulados estigma bífido. Fruto bacáceo, elipsoide, globoso ou ovoide. Semente discoide, envolvida em polpa gelatinosa.

Randia é um gênero neotropical, apresentando ca. 90 espécies (Gustafsson 2000), das quais oito ocorrem no Brasil (BFG 2015). Na SGLA, Randia está representada por duas espécies, que podem ser reconhecidas pelos ramos armados, frutos bacáceos com sementes discoides, envolvidas em polpa gelatinosa tornando-se negras quando ressecadas.

\section{Chave para espécies de Randia}

1. Lâmina foliar espatulada, fruto liso, verde quando maduro Randia calycina

1'. Lâmina foliar elíptica, fruto muricado, amarelo quando maduro Randia sp.

22.1. Randia calycina Cham., Linnaea. 9: 246. 1834.

Figs. $5 \mathrm{q} ; 9 \mathrm{e}, \mathrm{f}$

Árvore ca. $7 \mathrm{~m}$ alt. Ramos cilíndricos, espinescentes, estriados, esfoliantes, setosos a glabrescentes. Folhas pecioladas (pecíolo 3,6-6,8 mm compr.); estípula triangular, 2,6-3,6 × 1,9-2,4 $\mathrm{mm}$, glabra externamente, setosa internamente; lâmina espatulada, ápice acuminado, base atenuada, ca. 6,5-8,6 × 3-4,1 cm, lisa, papirácea, discolor, setosa. Tirso ou fascículo terminal, pedunculado (pedúnculo ca. 0,9 $\mathrm{mm}$ compr.); brácteas lanceoladas, $2,3-2,7 \times 0,4-0,9 \mathrm{~mm}$, castanhas, setosas nas margens. Flores masculinas sésseis; lobos do cálice lanceolados, 4,3-5,5 × 0,5-0,8 mm, verdes, pilosos; corola 15,9-21,6 mm compr., tubo ca. $12,8-16,9 \mathrm{~mm}$ compr., alvo, piloso externamente, tomentoso internamente, lobos elípticos a ovados, ápice arredondado, pilosos externamente, glabros internamente; anteras oblanceoladas ca. $3,4 \times 0,9 \mathrm{~mm}$ compr., alvas, glabras; estilete ca. $16,5 \mathrm{~mm}$ compr., alvo, glabro, lobos do estigma ca. $1 \mathrm{~mm}$ compr., glabros. Flores femininas não observadas. Fruto globoso, 19,6-22,1 × 17-17,8 mm, verde, liso, piloso. Semente $6,4-6,8 \times 5,3-7,2 \mathrm{~mm}$, creme, superfície lisa.

Material examinado: Licínio de Almeida, Lameirão, 5.XI.2013, fl. e fr., 1441'23,7'S, 42³2'35,7'W, R.L. Borges et al. 171 (ALCB, CEPEC, HUEFS); São
Domingos de Baixo, 22.I.2015, fr., 142'ㄷㄴ'S, 4231'6”'W, R.L. Borges et al. 258 (ALCB, HUEFS). Material adicional examinado: Licínio de Almeida, Lagoa da Vereda, 11.12.2009, fr., 1434'1's, 42'27'59”W, F.S. Gomes et al. 2009 (ALCB, HUEFS)

Randia calycina é uma espécie amplamente distribuída no país (BFG 2015). Na SGLA, $R$. calycina ocorre em áreas de floresta estacional, diferenciando-se de Randia sp. por apresentar lâmina foliar espatulada, (vs. elíptica) e fruto liso verde ( $v s$. fruto muricado amarelo). Em muitos herbários, espécimes com este padrão morfológico, tem sido identificado como $R$. armata, entretanto segui o conceito estabelecido por Judkevich et al. (2016).

\subsection{Randia sp.}

Figs. $5 \mathrm{p} ; 9 \mathrm{~g}$

Árvore 4-5 m alt.. Ramos espinescentes, cilíndricos, estriados, esfoliantes, setosos a glabrescentes. Folhas pecioladas (pecíolo $1,5-3 \mathrm{~mm}$ compr.); estípula triangular $2,2-2,8$ $\times 1,3-1,6 \mathrm{~mm}$, estrigosa externamente, setosa internamente; lâmina elíptica, ápice acuminado, base atenuada, $5,4-6,4 \times 1,9-3,5 \mathrm{~cm}$, lisa, papirácea, discolor, puberulenta. Flores não observadas. Fruto globoso, 15,7-17,3 × 16,4-17 $\mathrm{mm}$, amarelo-esverdeado, muricado, piloso. Semente 7,8-8,5 × 6,1-7,9 mm, castanha, superfície lisa. 
Material examinado: Licínio de Almeida, Mata estacional do Xaxá, 28.V.2014, fr., 14³9'1'S, 42³4'10,6”W, R.L. Borges et al. 193 (ALCB, CEPEC, HUEFS).

Material adicional examinado: Licínio de Almeida, Estrada para Urandi, 9.XII.2009, fr., 1444'43"'S, 42³1'2'W, E. Melo et al. 7366 (ALCB, HUEFS); Estrada Licínio de Almeida-Jacaraci, 1444'45”S, 42³1'3”W, M.L. Guedes et al. 16723 (ALCB); Caetité, $11 \mathrm{~km}$ de Maniaçu, 29.VIII.1999, fr., 1351'27'S, 42¹8'20”W, D.S. Carneiro-Torres et al. 106 (HUEFS)

Randia sp. está associada a áreas de floresta estacional. A ausência de flores nos materiais coletados na SGLA e naqueles analisados nos herbários, não permitiu até o momento, a identificação desta espécie. Este táxon é considerado inédito para a ciência, e está em processo de descrição (Gustafsson comm. pess.).

23. Remijia DC., Bibl. Univ. Genève 2: 185. 1829. Árvore ou arbusto. Ramos eretos, angulares. Folhas opostas ou verticiladas, pecioladas; estípula inteira; lâmina elíptica. Inflorescência em panícula ou tirso, terminal ou axilar. Flores pediceladas ou sésseis; cálice 5-6 lobado; corola 5-6 lobada, hipocrateriforme; anteras lineares a elípticas; ovário bilocular, lóculos pluriovulados, estigma bífido. Fruto seco, septicida, valvas bífidas no ápice, oblongo a elipsoide. Semente alada.

Remijia é um gênero Neotropical, apresentando ca. 40 espécies, das quais 21 ocorrem no Brasil (Andersson 1995; BFG 2015). O gênero tem distribuição predominantemente amazônica, havendo poucas espécies extra-amazônicas. Remijia caracteriza-se por apresentar inflorescência axilar ou terminal, fruto seco, com valvas bífidas no ápice e sementes aladas (Andersson 1995).

23.1. Remijia ferruginea DC., Prodr. 4: 357. 1830.

Fig. $9 h-j$

Arbusto ca. 1,5 m alt.. Ramos triangulares, estriados, tomentosos, ferrugíneos. Folhas pecioladas (pecíolo 0,6-1,5 cm compr.), trísticas; estípula triangular, 3,6 × 2,6 cm, tomentosa externamente, glabra internamente; lâmina obovada ou elíptica, revoluta, ápice agudo a arredondado, base atenuada, 0,7-1,7 ×0,2-0,6 cm, bulada, coriácea, discolor, glabra adaxialmente, serícea abaxialmente. Tirso axilar, pedunculado (pedúnculo 6,9-12 cm compr.); brácteas triangulares, 2,4-5,9 $\times$ 1,3-3,4 mm, ferrugíneas, tomentosas externamente, glabras internamente. Flores subsésseis (pedicelo 1,1-2,5 mm compr.) lobos do cálice triangulares, 1,2-1,4 × 0,4-1 mm, ferrugíneos, tomentosos; corola 1,4-1,9 cm compr., tubo $0,8-1,1 \mathrm{~cm}$, ferrugíneo, tomentoso externamente, glabro internamente, lobos triangulares, ápice agudo, alvos, tomentosos; anteras linear-lanceoladas, 3,6-4,7 $\times$ 0,7-1,2, cremes, glabras; estilete 7,2-9,6 mm compr., verde, glabro, lobos do estigma ca. 2,7 mm compr., glabros. Fruto elipsoide, 12,4-14,8 $\times$ 9,1-9,2 mm, ferrugíneo, tomentoso. Semente 3,4-5,3 × 3-3,5 mm, creme a ferrugínea, lisa.

Material examinado: Licínio de Almeida, Cachoeirão, 24.II.2012, fl., 1441'55'S, 42'32'58'W, F.A. Santana et al. 123 (ALCB, HUEFS); Riacho de areia, 27.V.2014, fl., 1445'32,5”'S, 42³4'38,3”W, R.L. Borges et al. 189 (ALCB, CEPEC, HUEFS).

Material adicional examinado: BRASIL. ESPIRITO SANTO: Marilândia, alto da liberdade, 14.VII.2011, fl. e fr., 19²0'46”'S, 40³2'59'W, J.G. de Carvalho-Sobrinho et al. 3148 (HUEFS)

Remijia ferruginea é uma espécie de distribuição restrita, ocorrendo nos domínios do Cerrado, associada a formações de campo rupestre e cerrado stricto sensu (BFG 2015). Na SGLA, $R$. ferruginea está associada a afloramentos rochosos, caracterizando-se por apresentar ramos triangulares, ferrugíneos, folhas trísticas, lâmina foliar bulada, ferrugínea quando seca, flores externamente tomentosas e lobos da corola alvos, tomentosos.

24. Richardia L., Sp. P1. 1: 330. 1753.

Ervas prostradas ou decumbentes. Ramos angulares ou cilíndricos. Folhas opostas, sésseis; estipula multifimbriada; lâmina foliar linear a ovada. Inflorescência em glomérulo, terminal. Flores sésseis; cálice 4-6 lobado, caduco; corola 4-6 lobada, infundibuliforme, alva a lilás; anteras lineares a oblongas, glabras; ovário 3-4 locular, lóculos um ovulado, estigma 2-6 lobados, cocleado. Fruto esquizocárpico, 3-4 mericarpos, papilosos. Semente elipsoide obovoide ou ovóide, plana ou sulcada ventralmente.

Richardia é um gênero americano com ca. 15 espécies (Lewis \& Oliver 1974; Bacigalupo 1968), das quais sete ocorrem no Brasil (BFG 2015). Richardia caracteriza-se por apresentar fruto esquizocárpico, composto por três a quatro mericarpos livres e cálice caduco, desprendendose do fruto.

24.1. Richardia grandiflora (Cham. \& Schlecht.) Steud., Nom. Bot. 2: 459. 1841. Figs. 5r-t; 9k,1

Ervas ca. $20 \mathrm{~cm}$ alt. Ramos cilíndricos, estriados, setosos. Folha peciolada (pecíolo 3,2-4,7 mm compr.); estipula 5-6 fimbriada, setosa; bainha 1,9-2,6 mm compr., fimbrias linear-triangulares, 3,2-5,1 × ca. 0,3 mm; lâmina elíptica, ápice 
agudo, base decorrente, 3-3,7 × 0,5-0,9 cm, lisa, cartácea, discolor, setosa. Glomérulo terminal, séssil; brácteas ovadas, foliares, 1-1,3 ×0,4-0,7 cm, verdes, setosas. Flores sésseis; cálice 6-lobado, lobos triangulares, 3-3,9 × 1,1-1,2 mm, verdes, setosos; corola 6-lobada, 0,8-1,2 cm compr., tubo ca. 7-9 mm compr., alvo, glabro, lobos triangulares, ápice agudo, alvos a lilás, setosos externamente, glabros internamente; anteras oblongas, ca. 1,4 × 0,6 mm, alvas, glabras; estilete ca. 2,8 mm compr., alvo, glabro, estigma 3-lobado, lobos cocleariformes, glabros. Fruto esquizocárpico, separando-se em três mericarpos, obovóides, 1,4-1,8 × 1-1,6 mm, verdes a castanhos, papilosos. Semente obovoide 1,2-1,7 $\times$ 0,6-1 mm, ferrugínea, lisa.

Material examinado: Licínio de Almeida, Rodovia para Urandi, fl. e fr., 1471'30,5'S, 42 50'91'W, J.G. Jardim et al. 3316 (CEPEC); Cascarrento, 6.VII.2014, fl. e fr., 14'55'44"S, 4255'72'W, N. Roque et al. 4442 (ALCB); Saco da Onça, 27.V.2015, 1444'38,3”S, 42³2'22,5’W, fl. e fr., R.L. Borges et al. 186 (ALCB, CEPEC, HUEFS); São Domingos de Baixo, 22.I.2015, 14²7'21,5"S, 42031'6”W, R.L. Borges et al. 257 (ALCB, CEPEC, HUEFS); Xaxá, 12.V.2015, 14³9'11'S, 42³3'13,4”W, R.L. Borges et al. 271 (ALCB, CEPEC, HUEFS).

Richardia grandiflora é uma espécie amplamente distribuída na América do Sul (Bacigalupo 1968) e no Brasil, ocorre associada principalmente a áreas antropizadas (BFG 2015). Richardia grandiflora caracteriza-se por apresentar flores alvas ou lilás e mericarpos com indumento papiloso. Na SGLA, R. grandiflora ocorre em áreas antropizadas.

25. Sabicea Aubl., Hist. Pl. Guiane 1: 192. 1775. Arbustos, ervas ou trepadeiras. Ramos cilíndricos, eretos, escandentes ou prostrados. Folhas opostas ou verticiladas, pecioladas; estípula inteira; lâmina foliar elíptica, lanceolada ou ovada, lanosa ou tomentosa. Inflorescência em glomérulo ou tirso, axilar, pedunculada ou séssil. Flores sésseis a subsésseis; cálice 5-lobado; corola 5-lobada, hipocrateriforme ou infundibuliforme; anteras lineares a oblongas; ovário 2-5 locular, pluriovulado, estigma 2-5 lobado. Fruto bacáceo, elipsoide a globoso, esponjoso. Semente ovoide ou tetraédrica.

Sabicea é um gênero amplamente distribuído, com ca. 106 espécies (Mendaçolli 2007), ocorrendo em diversos continentes (Wernham 1914). No Brasil, são encontradas 19 espécies associadas a diversas formações vegetais (BFG 2015). Sabicea caracteriza-se por apresentar ramos e folhas com indumento denso e inflorescência axilar, geralmente glomérulos, e fruto bacáceo multisseminado, esponjoso quando maduro.

25.1. Sabicea brasiliensis Wernham, Monogr. Sabicea 51: 12. 1914.

Fig. 10a

Arbusto ca. $30 \mathrm{~cm}$ alt. Ramos eretos, lanosos. Folhas pecioladas (pecíolo 2,6-4,5 mm compr.); estípula largamente ovada, ca. 5,8 ×5 mm, lanosa externamente, glabra internamente; lâmina elíptica, ápice agudo, base atenuada, 4,3-5,5 × 1,8-2,1 $\mathrm{cm}$, cartácea, discolor, lanosa. Inflorescência em glomérulo, séssil; brácteas lanceoladas 3,3-4,5× ca. $2 \mathrm{~mm}$, lanosas externamente, glabras internamente. Flores sésseis; lobos do cálice ovados, ca. 2,7 × 1,5 $\mathrm{mm}$, lanosos; corola hipocrateriforme, ca. $8,7 \mathrm{~mm}$ compr., tubo ca. 4,7 mm compr., creme, lanoso externamente, tomentoso internamente, lobos ovados, ápice agudo, creme, lanosos externamente, tomentosos internamente; anteras estreitamente oblongas, ca. 2, $1 \times 0,5 \mathrm{~mm}$, glabras; estilete ca. 4,7 $\mathrm{mm}$ compr., tomentoso. Fruto imaturo, globoso, 3 $\times$ 3,3 mm, lanoso. Semente tetraédrica, 0,7 × 0,7 $\mathrm{mm}$, ferrugínea, superfície linear.

Material examinado: Licínio de Almeida: Cerrado após Mata estacional do Xaxá, 21.I.2015, fl., 14³8'44,5”S, 42'33'17,8'W, R.L. Borges et al. 240 (ALCB, CEPEC, HUEFS).

Sabicea brasiliensis, ocorre da Bolívia ao Brasil, em diversos estados brasileiros, associada a diversos domínios e fitofisionomias (Wernham 1914; BFG 2015). S. brasiliensis caracteriza-se por apresentar ramos eretos, lâmina foliar com indumento denso lanoso na superfície abaxial. Na SGLA, Sabicea brasiliensis está associada a fitofisionomias de cerrado sensu stricto.

26. Stachyarrhena Hook.f., Hooker's Incon Pl. 11: 1068. 1870.

Árvores. Ramos eretos, cilíndricos. Folhas opostas, pecioladas; estípula inteira; lâmina foliar elíptica, oblonga ou obovada. Inflorescência espiciforme (flores masculinas) ou uniflora (flores femininas). Flores sésseis; cálice 5-lobado, lobos fusionados em estrutura cupuliforme, verde; corola 5-lobada, infundibuliforme, lobos da corola ovados; anteras lineares; ovário 4-5 locular, lóculos pluriovulados, estigma bífido. Fruto carnoso, bacáceo, globoso ou elipsoide, verde. Semente aplanada, envolvida em polpa gelatinosa.

Stachyarrhena é um gênero neotropical com ca. 13 espécies (Govaerts et al. 2016). No Brasil são registradas sete espécies, distribuídas principalmente ao longo do domínio Amazônico 
(BFG 2015). Stachyarrhena caracteriza-se por apresentar flores unissexuais (flores masculinas organizadas em inflorescências espiciformes e flores femininas em inflorescência uniflora) e frutos carnosos bacáceos com sementes planas envolvida em polpa gelatinosa (Delprete 2010).

26.1. Stachyarrhena reflexa Standl., Publ. Field Mus. Nat. Hist., Bot. Ser. 22: 125. 1940.

Figs. 10b-e; 11e-j

Árvore ca. $3 \mathrm{~m}$ alt. Ramos, glabros. Folhas pecioladas (pecíolo ca. 1,1-1,3 cm compr.); estípula triangular, ca. $4 \times 3,3 \mathrm{~mm}$ compr., ápice agudo, glabra; lâmina obovada, ápice arredondado, base atenuada, 4,7-7,7 × 1,7-3,5 cm, lisa, discolor, glabra. Inflorescência masculina, pedunculada (pedúnculo 1,2-1,9 $\mathrm{cm}$ compr.); desprovida de brácteas. Flores masculinas sésseis; cálice ca. $2 \mathrm{~mm}$ compr., verde, glabro; corola ca. $8 \mathrm{~mm}$ compr., tubo ca. 4,2 mm compr., creme, glabro externamente, tomentoso internamente, lobos ovados, cremes, glabros; anteras ca. 3,5 ×0,8 mm, glabras; estilete ca. $3 \mathrm{~mm}$ compr., glabro, lobos do estigma ca. $3,1 \mathrm{~mm}$ compr., glabros. Fruto obovoide, 2,2-2,5 $\times 1,4-1,8 \mathrm{~cm}$, verde, glabro. Semente 5,5-5,9 $\times$ $3,2-4,2 \mathrm{~cm}$, castanha, lisa.

Material examinado: Licínio de Almeida, Trilha XaxáCachoeirão, 28.V.2014, fr., 1441'3,5'’S, 42³2'44,1'”W, R.L. Borges et al. 198 (ALCB, CEPEC, HUEFS); Mata após Campo rupestre do Xaxá, 21.I.2015, fl. e fr., 14³8'44,5”S, 42³3'17,8”'W, R.L. Borges et al. 243 (ALCB, CEPEC, HUEFS).

Stachyarrhena reflexa é uma espécie com distribuição restrita à Bahia e Minas Gerais, ocorrendo em formações de floresta estacional e cerrado sensu stricto (BFG 2015). Na SGLA, esta espécie foi encontrada associada a áreas de floresta estacional, caracterizando-se por apresentar ramos glabros, folhas obovadas, flores masculinas cremes e frutos sempre verdes.

27. Staelia Cham. \& Schult., Linnaea 3: 364. 1828. Ervas, arbustos ou subarbustos. Ramos eretos, cilíndricos ou angulares. Folhas opostas ou verticiladas, sésseis; estípula pauci-multifimbriada; lâmina foliar estreitamente elíptica, lanceolada a linear. Inflorescência em glomérulos, axilares ou terminais. Flores sésseis ou subsésseis; cálice 2-lobado, persistente no fruto; corola 4-lobada, campanulada ou infundibuliforme; anteras oblongas; ovário 2-locular, um óvulo por lóculo, estigma bífido ou capitado. Fruto seco, capsular, deiscência transversal oblíqua. Semente plano-convexa, sulcada ventralmente.

Staelia é um gênero neotropical apresentando ca. 20 espécies (Govaerts et al. 2016), distribuídas predominantemente na América do Sul (Salas \& Cabral 2012). No Brasil, o gênero está representado por ca. 14 espécies, muitas restritas e recentemente descritas (Salas \& Cabral 2006a,b, 2011). Staelia caracteriza-se por apresentar hábito geralmente arbustivo, folhas sésseis, frutos capsulares com deiscência transversalmente oblíqua e sementes plano-convexas com sulco longitudinal na face ventral. Na SGLA, Staelia está representada por duas espécies, Staelia virgata e Staelia sp., ocorrendo em áreas de campo reupestre e caatinga rupestre, respectivamente.

\section{Chave para as espécies de Staelia}

1. Estípula 8-9 fimbriada; corola infundibuliforme, 5,8-6,2 $\mathrm{mm}$ compr.............................Staelia virgata

1'. Estípula 3-5 fimbriada; corola campanulada ca. 2,6 mm compr. Staelia sp.

27.1. Staelia virgata (Link. ex Roem. \& Schult.) K.Schum., Fl. bras. 6(6): 76. $1888 . \quad$ Fig. 10f,g Arbusto até $50 \mathrm{~cm}$. alt.. Ramos angulares, estriados, puberulentos. Folhas verticiladas; estípula 8-9 fimbriada, bainha 1,1-1,5 mm compr., fimbrias estreitamente triangulares, $1-2 \times 0,2-0,4$ $\mathrm{mm}$; lâmina lanceolada, revoluta, ápice acuminado, base truncada, 4,6-5,5 × 0,9-1,3 mm, lisa, cartácea, concolor, puberulenta. Brácteas lanceoladas, foliares, 4-4,5 × ca. $1 \mathrm{~mm}$. Flores sésseis; lobos do cálice triangulares $2,3-2,9 \times 0,6-0,8 \mathrm{~mm}$, verdes, puberulentos; corola infundibuliforme,
5,8-6,2 mm compr., tubo 4,2-4,5 mm compr., alvo, puberulento externamente, glabro internamente, lobos triangulares, ápice agudo, alvos, puberulentos externamente, glabros internamente; anteras ca. 1 $\times 0,5 \mathrm{~mm}$, alvas, glabras; estigma bífido, lobos ca. $0,5 \mathrm{~mm}$ compr., papilosos. Fruto $1-1,3 \mathrm{~mm}$ compr., verde a castanho, piloso. Semente ca. 0,8 $\times 0,6 \mathrm{~mm}$, castanha, foveolada, glabra.

Material examinado: Licínio de Almeida, $2 \mathrm{~km}$ após o Povoado do Riacho Fundo, 11.XII.2009, fl. e fr., 14'57'13,8'S, 4252'41,7'W, E. Melo 7492 (HUEFS); Trilha ao lado da Cachoeira das Sete Quedas, 22.V.2013, 
fl., 14³1'1,5”S, 42`32'W, R.L. Borges et al. 135 (ALCB, CEPEC, HUEFS); Fazenda Riacho de Areia, 27.V.2014, fl. e fr., 1445'32'S, 42³4'38'W, R.L. Borges et al. 188 (ALCB, CEPEC, HUEFS); Fazenda Riacho de Areia, 20.I.2015, fl., 1445'32'S, 42³4'38”W, R.L. Borges et al. 217 (ALCB, HUEFS); Campo rupestre do Xaxá, 23.I.2015, fl. e fr., 14³9'11'S, 42³3'03”'W, R.L. Borges et al. 237 (ALCB, HUEFS).

Staelia virgata é uma espécie amplamente distribuída, ocorrendo em diversos domínios fitogeográficos e associada a diversas formações vegetais (BFG 2015). Na SGLA, S. virgata está associada a formações de campo rupestre e áreas antropizadas, apresentando ampla variação morfológica, diferenciando-se de Staelia sp. por apresentar flores com corola infundibuliforme ( $v s$. corola campanulada) e corola 5,8-6,2 mm compr. (vs. 2,7 mm compr.).

\subsection{Staelia sp.}

Figs. 5u-w; 10h-j

Arbusto ca. $30 \mathrm{~cm}$ alt. Ramos cilíndricos, estriados, esfoliantes, puberulentos. Folhas verticiladas, sésseis; estípula 3-5 fimbriada, puberulenta, bainha ca. 0,7 mm compr., fimbrias linear-triangulares, ca. 0,5 × 0,1 mm; lâmina linear-lanceolada, ápice agudo, base truncada, 2-5 $\times$ 0,4-0,6 mm, lisa, cartácea, concolor, glabra. Inflorescência em glomérulo, axilar; brácteas linear-lanceoladas, foliáceas, ca. 1,3 × 0,4 mm, verdes, puberulentas. Flores sésseis; lobos do cálice triangulares, ca. $1 \times 0,3 \mathrm{~mm}$, puberulentos; corola campanulada ca. 2,7 mm compr., tubo ca. 1,7 mm compr., alvo, puberulento externamente, glabro internamente; lobos deltados, ca. $1 \times 1 \mathrm{~mm}$, ápice agudo, alvos, puberulentos externamente, glabros internamente; anteras ca. 0,6 × 0,4 mm, alvas, glabras; estilete ca. 2,6 mm compr., alvo, glabro, estigma bífido, lobos ca. 0,2 mm compr., papilosos. Fruto ca. $0,8 \times 1 \mathrm{~mm}$, verde a castanho, puberulento. Semente $0,7 \times 0,6 \mathrm{~mm}$, atropurpúrea, superfície foveolada.

Material examinado: Licínio de Almeida, Garimpo das ametistas, 5.XI.2013, fl. e fr., 14³1'44,1'S, 42³2'4”'W, R.L. Borges et al. 204 (ALCB, CEPEC, HUEFS); Garimpo das ametistas, 29.V.2014, fl. e fr., 14³1'44,1'S, 4232'4”W, R.L. Borges et al. 204 (ALCB, CEPEC, HUEFS); Garimpo das ametistas, 20.I.2015, fl. e fr., 14'31'44,1'S, 42³2'4”'W, R.L. Borges et al. 253 (ALCB, CEPEC, HUEFS).

Staelia sp. ocorre na SGLA associada a áreas de caatinga rupestre, em substrato arenoso. Segundo Salas (com. pess.), está espécie é uma provável espécie nova tendo sido coletada em fruto no município de Brejinhos das Ametistas, localidade contígua a SGLA.
28. Tocoyena Aubl., Hist. P1. Guiane 1: 131. 1775. Arbustos, árvores ou subarbustos. Ramos cilíndricos, eretos. Folhas opostas, pecioladas; estípula inteira; lâmina foliar elíptica, oblonga, obovada ou lanceolada. Inflorescência em corimbo ou dicásio, terminal, pedunculada. Flores sésseis ou subsésseis; cálice 5-lobado, lobos fusionados; corola 5-lobada, longa tubular, hipocrateriforme ou infundibuliforme; anteras lineares a oblongas; ovário bilocular, lóculos pluriovulados, estigma bífido. Fruto carnoso bacáceo, verde a amarelo. Semente aplainada, discoide, envolvida em polpa gelatinosa.

Tocoyena é um gênero neotropical, apresentando ca. 19 espécies (Govaerts et al. 2016), das quais 12 ocorrem no Brasil (BFG 2015). Tocoyena caracteriza-se por apresentar estípula inteira, flores longo tubulares, hipocrateriforme ou infundibuliforme; frutos bacáceos e sementes planas envolvidas em polpa gelatinosa.

28.1. Tocoyena formosa K.Schum., Fl. bras. 6(6): 347. 1889.

Fig. 10k,1

Arbusto ca. 1,5 m alt. Ramos estriados, tomentosos a glabrescentes. Folhas pecioladas (pecíolo 0,5-0,8 cm compr.); estípula deltada, 5,8-6,4 × ca. $6 \mathrm{~mm}$, pilosa; lâmina elíptica, ápice agudo, base atenuada, 6-6,3 × 4,9-5,4 cm, lisa, cartácea, discolor, denso tomentosa. Corimbo terminal, pedunculado (pedúnculo ca. 2,5 mm compr.); brácteas triangulares, 1,5-1,9 × 0,7-1 mm, ferrugíneas, setosas. Flores subsésseis (pedicelo ca. $2 \mathrm{~mm}$ compr.), ca. $6 \mathrm{~cm}$ compr.; cálice ca. $1 \mathrm{~mm}$ compr., verde, piloso; corola infundibuliforme, 4,3-5, $1 \mathrm{~cm}$ compr., tubo 3-3,6 cm compr., creme, tomentoso externamente, glabro internamente, lobos ovados, ápice arredondado, cremes, tomentosos externamente, glabros internamente; anteras oblongas, ca. $6 \times 2 \mathrm{~mm}$, alvas, glabras; estilete ca. $4,5 \mathrm{~cm}$ compr., verde, lobos do estigma ca. $6 \mathrm{~mm}$ compr., glabros. Fruto globoso, 2,9-3,7×2,7-3,2 cm, piloso. Semente ca. $7 \times 6 \mathrm{~mm}$, ferrugínea, lisa, glabra. Material examinado: Licínio de Almeida, Saco da Onça, IX.2014, fl. e fr., 1444'38,9'S, 42 34'22,5'W, R.L. Borges et al. 05 (ALCB, CEPEC, HUEFS).

Tocoyena formosa é uma espécie amplamente distribuída nos domínios fitogeográficos brasileiros, com destaque para as áreas de Cerrado (Prado 1987; Silberbauer-Gottsberger et al. 1992). T. formosa caracteriza-se por apresentar folhas com indumento denso tomentoso, estípula deltada, flores com corola longa-tubular, infundibuliforme e lobos da corola ovados com ápice arredondado. 


\section{Agradecimentos}

$\mathrm{O}$ primeiro autor agradece à CAPES, a bolsa concedida para a realização do Mestrado junto ao programa de Pós-graduação em Botânica. Os autores agradecem à FAPESB (PNE 1642/2011; APR 0174/2015) e ao CNPq (AAPP0049/2009), os recursos disponibilizados para as viagens de campo e vistas aos herbários. A última autora agradece ao $\mathrm{CNPq}$, a bolsa de Produtividade em Pesquisa.

\section{Referências}

Achille, F.; Motley, T.J.; Lowry II, P.P. \& Jéremie, J. 2006. Polyphyly in Guettarda L. (Rubiaceae, Guettardeae) based on NRDNA its sequence data. Annals of Missouri Botanical Garden 93: 103-121.

Alves, M.; Santana, F.A. \& Roque, N. 2015. New records of thirteen Asteraceae from state of Bahia, Brazil. CheckList 11: 1-5.

Andersson, L. 1995. Tribes and genera of the Cinchoneae complex. Annals of the Missouri Botanical Garden 82: 409-427.

Bacigalupo, N.M. 1968. Revisión de las espécies del género Richardia (Rubiaceae) en la flora argentina. Darwiniana 14: 639-653.

Bacigalupo, N.M. \& Cabral, E.L. 2007. Diodella. In: Mendaçolli, S.J. Rubiaceae. Instituto de Botânica de São Paulo, São Paulo. 313p.

Barbosa, M.R. 2007. Chomelia. In: Mendaçolli, S.J. (ed.). Rubiaceae. Instituto de Botânica de São Paulo, São Paulo. 285p.

Beentje, H. 2010. The Kew plant glossary: an illustrated dictionary of plant terms. Royal Botanical Garden, Kew, London. 164p.

BFG, 2015. Growing knowledge: an overview of seed plant diversity in Brazil. Rodriguésia 66: 1085-1113.

Cabral, E.L. 2009. Revision Sinótipica de Galianthe subgen. Galianthe (Rubiaceae: Spermacoceae) com uma sección nueva. Annals of Missouri Botanical Garden 96: 26-70.

Cabral, E.L. \& Bacigalupo, N.M. 2005. Novelities in Rubiaceae-Spermacoceae from Bolivia and Paraguay (Diodella). Brittonia 5: 129-140.

Cabral, E.L.; Miguel, L.M. \& Salas, R.M. 2011. Dos espécies nuevas de Borreria (Rubiaceae), synopsis y clave das espécies para Bahia, Brasil. Acta Botanica Brasilica 25: 255-276.

Campos, L.; Guedes, M.L.S.; Acevedo-Rodríguez, P. \& Roque, N. 2016. Contributions to the floristic and vegetation knowledge of Espinhaço Septentrional, Bahia, Brazil. Brazilian Journal of Botany. Disponível em $<$ https://doi.org/10.1007/s40415016-0347-y>. Acesso em 17 janeiro 2017.

Campos, M.T.A; Zappi, D.C.; Calió, M.F. \& Pirani, J.R. 2006. Flora de Grão Mogol, Minas Gerais: Rubiaceae. Boletim de Botânica da Universidade de São Paulo 24: 41-67.
Chaw, S.M. \& Peng, C.I. 1987. Remarks on the species of Spermacoceae (Rubiaceae) of Taiwan. Journal of the Taiwan Museum 40: 71-83.

Coutinho, L.M. 1978. O conceito de Cerrado. Revista Brasileira de Botânica 1: 17-23.

CPRM. 2008. Mapa de geodiversidade do estado da Bahia (shape-file). Disponível em $<$ http://geobank.cprm.gov. br/>. Accesso em maio 2016.

Davis, A.; Govaerts, R.; Bridson, D.M.; Ruhsam, M.; Moat, J. \& Brummitt, N.A. 2009. A global assessment of distribution, diversity, endemism and taxonomic effort in Rubiaceae. Annals of Missouri Botanical Garden 96: 68-78.

De Block, P. 1998. The African species of Ixora (Rubiaceae, Pavetteae). Opera Botanica Belgica 9: 1-218.

Delprete, P.G. 1997. Revision and typification of Brazilian Augusta (Rubiaceae, Rodeletieae), with ecological observation on the riverine vegetation of the cerrado and Atlantic forests. Brittonia 49: 487-497.

Delprete, P.G. 2004. Rubiaceae. In: Smith, N.P. et al. (eds.). Flowering plant families of the American tropics. Princeton University Press, New York Botanical Garden Press, Princeton. Pp. 328-333.

Delprete, P.G. 2010. Stachyarrhena. In: Rizzo, J.A. (ed.). Flora dos estados de Goiás e Tocantins. Vol.40. IRD/ UFG, Goiania. Pp. 1310-1314.

Delprete, P.G. \& Jardim, J.G. 2012. Systematics, taxonomy and floristics of Brazilian Rubiaceae: an overview about the current status and future challenges. Rodriguésia 63: 101-128.

Giulietti, A.M.; Menezes, N.L.; Pirani, J.R.; Meguro, M. \& Wanderley, M.G.L. 1987. Flora da Serra do Cipó, Minas Gerais: caracterização e lista de espécies. Boletim de Botânica da Universidade de São Paulo 9: 1-151.

Giulietti, A.M.; Queiroz, L.P.; Silva, T.R.S.; França, F.; Guedes, M.L. \& Amorim, A.M. 2006. Flora da Bahia. Sitientibus 6: 169-173.

Govaerts, R.; Ruhsam, M.; Andersson, L.; Robbrecht, E.; Bridson, D.; Davis, A.; Schanzer, I. \& Sonké, B. 2016. World checklist of Rubiaceae. The broad of trustees of Royal Botanical Gardens, Kew. Disponível em $<$ http://www.kew.org/wcsp/rubiaceae $>$. Acesso em janeiro 2016.

Gustafsson, C.G.R. 2000. Three new south american species of Randia (Rubiaceae, Gardenieae). Novon 10: 201-208.

Hurbath, F.; Torres, D.C.; Roque, N. 2016. Euphorbiaceae na Serra Geral de Licínio de Almeida, Bahia, Brasil. Rodriguésia 67: 489-531.

IBGE. 2012. Manual técnico da vegetação brasileira. Instituto Brasileiro de Geografia e Estatística, Rio de Janeiro. Disponível em <http://biblioteca.ibge. gov.br/visualizacao/livros/liv63011.pdf $>$. Acesso em maio 2015.

Jardim, J.G. 2008. Filogenia aplicada à taxonomia de Faramea Aubl. (Rubiaceae, Coussareae) e revisão da Seção Hypochasma Mull. Arg. Tese de Doutorado. 
Universidade Estadual de Feira de Santana, Feira de Santana. 168p.

Judkevich, M.D.; Salas, R.M. \& Keller, H. 2016. Randia brevituba (Rubiaceae), a new specie from Southern Cone of America and comments on Randia armata. Systematic Botany 41: 238-244.

Kirkbride, J.H.Jr. 1976. A revision of the genus Declieuxia (Rubiaceae). Memoirs of New York. Botanical Garden 28: 1-87.

Kirkbride, J.H.Jr. 1979. Revision of the genus Psyllocarpus. Smithsonian contributions to Botany 41: 1-32.

Kirkbride, J.H. 1997. Manipulus Rubiacearum. VI. Brittonia 49: 354-379.

Lewis, W.H. \& Oliver, R.L. 1974. Revision of Richardia. Brittonia 26: 271-301.

Macias, L.F. 1988. Revisão taxonômica do gênero Posoqueria Aubl. (Rubiaceae). Tese de Doutorado. Universidade Estadual de Campinas, Campinas. 178p.

Marinero, F.E.C.; Rodrigues, W.A. \& Cervi, A.C. 2012. Manettia (Rubiaceae) no estado do Paraná. Rodriguésia 63: 635-647.

Mendaçolli, S.L.J. 2007. Chiococca. In: Mendaçolli, S.J. (ed.). Rubiaceae. Instituto de Botânica de São Paulo, São Paulo. 285p.

Mori, S.A.; Silva, L.A.M.; Lisboa, G. \& Coradin, L. 1989. Manual de manejo do herbário fanerogâmico.Centro de Pesquisa do Cacau, Ilhéus. Pp. 1-104.

Pereira, M.S. 2007. O gênero Coussarea Aubl. (Rubiaceae, Rubioideae, Coussareae) na Floresta Atlântica. Tese de Doutorado. Universidade Federal de Pernambuco, Recife. 137 p.

Persson, C. \& Delprete, P.G. 2010. Cordiera longicaudata sp. nov. and Duroia valesca sp. nov. of the Alibertia group (Gardenieae-Rubiaceae). Nordic Journal of Botany 28: 523-527.

Prado, A.D. 1987. Revisão taxonômica do gênero Tocoyena Aubl. (Rubiaceae) no Brasil. Dissertação de Mestrado. Universidade Estadual de Campinas, Campinas. 194p.

Radford, A.E.; Dickson, W.C.; Massey, J.R. \& Bell, C.R. 1974. Vascular plant systematics. Harper \& Row Pub., New York. 498p.

Robbrecht, E. 1988. Tropical woody Rubiaceae. Characteristic features and progressions. Contributions to a new subfamilial classification. Opera Botanica Belgica 1: 1-271.

Roque, N. \& Santana, F.A. 2014. A new species for a monotypic genus: Anteremanthus (Asteraceae: Vernonieae). Systematic Botany 39: 656-661.

Salas, R.M. \& Cabral, E.L. 2006a. Una nueva especie y una nueva conbinacion em el genero Staelia (RubiaceaeSpermacoceae) de Bolivia. Darwiniana 44: 500-503.

Salas, R.M. \& Cabral, E.L. 2006b. Uma nueva especie del genero Staelia para la flora de Brasil. Revista de Biologia Neotropical 3: 1-3.
Salas, R.M. \& Cabral, E.L. 2011. Dos espécies nuevas de Staelia com hojas ternadas de Brasil. Brittonia 63: 355-364.

Salas, R.M. \& Cabral, E.L. 2012. Two new shrubby species of the genus Staelia from Serra do Curral Frio, Bahia, Brazil, Systematic Botany 37: 507-515.

Santana, F.A. 2013. Asteraceae na Serra Geral de Licínio de Almeida, Bahia, Brasil. Disertação de Mestrado, Feira de Santana. 143p.

Secretaria de Desenvolvimento e Ação Regional (SEDIR). 2007. Plano de desenvolvimento regional sustentável da Serra Geral. Salvador. Disponível em $<$ http://www.car. ba.gov.br/wp-content/uploads/2013/09/Perfil-RegionalSerra-Geral.pdf $>$. Acesso em maio 2015.

Silberbauer-Gottsberger, I.; Gottsberger, G. \& Erhendorfer, F. 1992. Hybrid speciation and radiation in the neotropical woody genus Tocoyena. Plant Systematics and Evolution 181: 143-169.

Sousa, L.A.; Bautista, H.P. \& Jardim, J.G. 2013. Diversidade florística de Rubiaceae na Serra da Fumaça - complexo de Serras da Jacobina, Bahia, Brasil. Biota Neotropica 13: 289-314.

Souza, E.B.; Cabral, E.L. \& Zappi, D.C. 2010. Revisão de Mitracarpus (Rubiaceae - Spermacoceae) para o Brasil. Rodriguésia 61: 319-352.

Taylor, C.M. 1997. Conspectus of Palicourea (Rubiaceae: Psychotrieae) with the description of some new species from Ecuador and Colombia. Annals of Missouri Botanical Garden 84: 224-226.

Taylor, C.M. 2005. Margaritopsis (Rubiaceae, Psychotrieae) in the Neotropics. Systematics and Geography of Plants 75: 161-177.

Taylor, C.M. 2007. Psychotria. In: Mendaçolli, S.J. (ed.). Rubiaceae. Instituto de Botânica de São Paulo, São Paulo. 285p.

Taylor, N.P. \& Zappi, D. 2004. Cacti of Eastern Brazil. Royal Botanical Gardens, Kew. 499p.

Thiers, B. [continuously updated]. Index herbariorum: a global directory of public herbaria and associated staff. New York Botanical Garden's Virtual Herbarium. Disponível em $<$ http://sweetgum.nybg.org/science/ih/ $>$. Acesso em dezembro 2015.

Varjão, R.R.; Jardim, J.G. \& Conceição, A.S. 2013. Rubiaceae Juss. de caatinga naAPA Serra Branca/Raso da Catarina, Bahia, Brasil. Biota Neotropica 13: 105-123.

Wernham, H.F. 1914. A monograph of the genus Sabicea. London Trustees of the Britsh Museum 12: 1-82.

Zappi, D.; Calió, M.F. \& Pirani, J.R. 2014. Flora da Serra do Cipó, Minas Gerais: Rubiaceae. Boletim de Botânica da Universidade de São Paulo 32: 71-140.

Zappi, D.C. \& Stannard, B.L. 1995. Rubiaceae. In: Stannard, B.L. Flora do Pico das Almas, Chapada Diamantina, Bahia, Brazil. Royal Botanical Gardens, Kew, Londres. Pp. 546-578. 